\title{
Bechtel Mevada
}

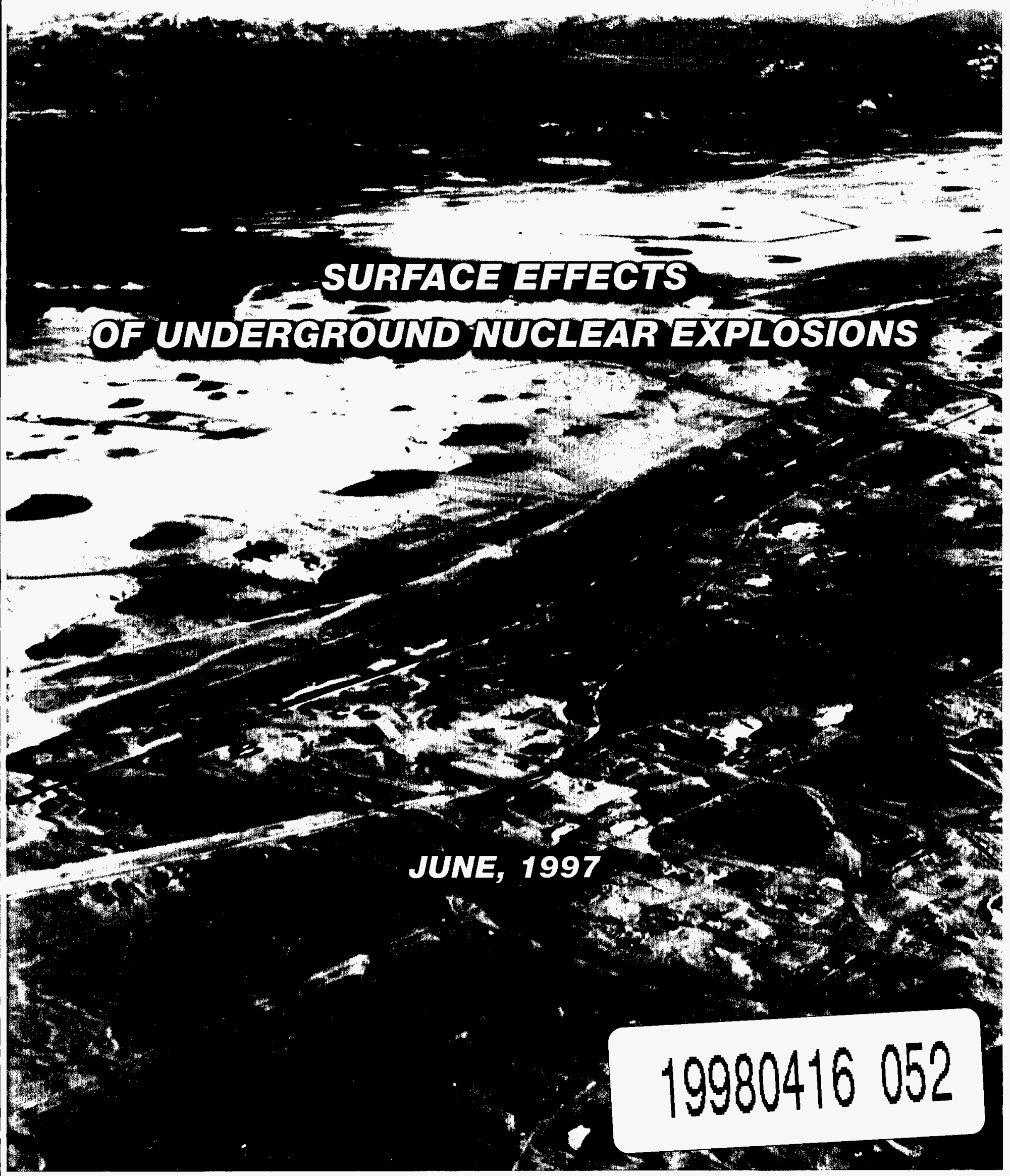




\section{REPRODUCTION QUALITY NOTICE}

This document is the best quality available. The copy furnished to DTIC contained pages that may have the following quality problems:

- Pages smaller or larger than normal.

- Pages with background color or light colored printing.

- Pages with small type or poor printing; and or

- Pages with continuous tone material or color photographs.

Due to various output media available these conditions may or may not cause poor legibility in the microfiche or hardcopy output you receive.

If this block is checked, the copy furnished to DTIC contained pages with color printing, that when reproduced in Black and White, may change detail of the original copy. 


\title{
SURFACE EFFECTS \\ OF UNDERGROUND NUCLEAR EXPLOSIONS
}

\author{
Brian M. Allen \\ Sigmund L. Drellack Jr. \\ Margaret J. Townsend
}

Geotechnical Services

Bechtel Nevada

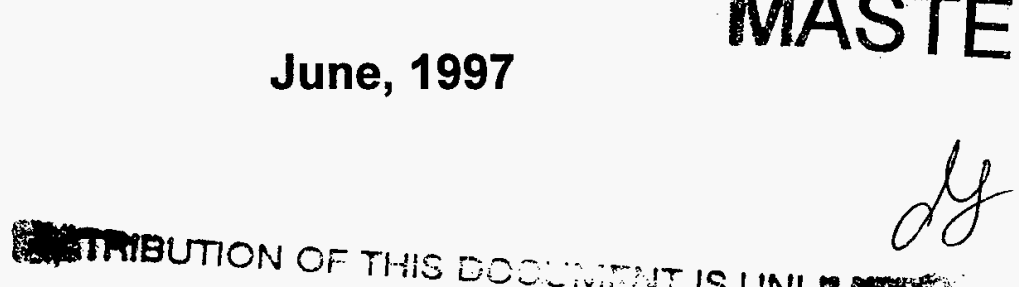

MASTER

Prepared for the U. S. Department of Energy Nevada Operations Office under contract No. DE-AC08-96NV11718 


\section{DISCLAIMER}

This report was prepared as an account of work sponsored by the United States Government. Neither the United States nor the United States Department of Energy, nor any of their employees, makes any warranty, express or implied, or assumes any legal liability or responsibility for the accuracy, completeness, or usefulness of any information, apparatus, product, or process disclosed, or represents that its use would not infringe privately owned rights. Reference herein to any specific commercial product, process or service by trade name, mark, manufacturer, or otherwise, does not necessarily constitute or imply its endorsement, recommendation, or favoring by the United States Government or any agency thereof. The views and opinions of authors expressed herein do not necessarily state or reflect those of the United States Government or any agency thereof.

This report has been reproduced from the best available copy.

Available to DOE and DOE contractors from:

Office of Scientific and Technical Information

P.O. Box 62

Oak Ridge, TN 37831

For prices call (423) 575-8401

Available to the public from:

National Technical Information Service

U. S. Department of Commerce

5285 Port Royal Rd.

Springfield, VA 22161 


\section{CONTENTS}

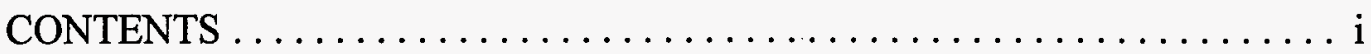

ACKNOWLEDGMENTS $\ldots \ldots \ldots \ldots \ldots \ldots \ldots \ldots \ldots \ldots \ldots$ vii

1.0

2.0

2.1

2.2

2.2 .1

2.3

2.4

3.0

3.1

3.1 .1

3.1 .2

3.1 .3

3.1 .4

3.1 .5

3.1 .6

3.1.6.1

3.1.6.2

3.1.6.3

3.1 .7

3.1 .8

3.1.8.1

3.1.8.2

3.1.8.3

3.1 .9

3.1 .10

3.1 .11

3.1.11.1

3.1.11.1.1

3.1.11.1.2

3.1.11.1.3

3.1.11.1.4

3.1.11.1.5

3.1.11.2

3.1.11.2.1

3.1.11.2.2

3.1.11.3
INTRODUCTION

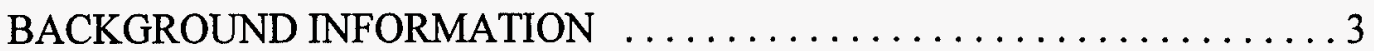

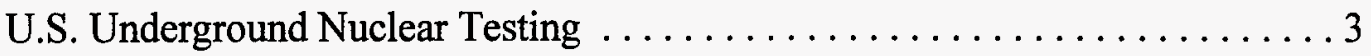

The Nevada Test Site ............................ 3

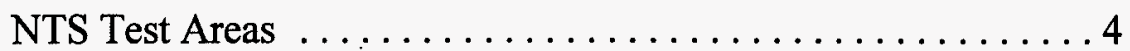

Other Locations of U.S. Underground Nuclear Tests $\ldots \ldots \ldots \ldots \ldots 4$

Phenomenology of Underground Nuclear Explosions . . . . . . . . . 8

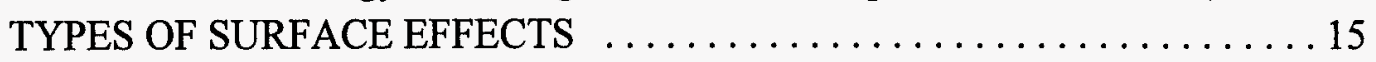

Geologic and Hydrologic Effects .................... 15

Previous Investigations and Documentation Efforts ....... 15

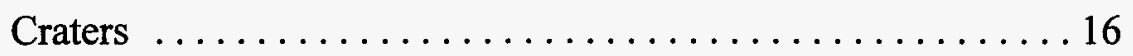

Collapse Sinks ......................... 20

Depressions and Domes .................... 26

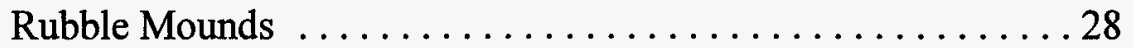

Surface Cracks ......................... 28

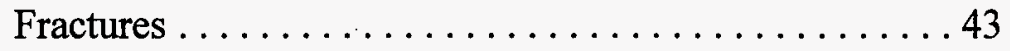

Faults .............................47

Block Chatter ........................ 52

Rock Spall ........................... 52

Mass Movement ........................... 55

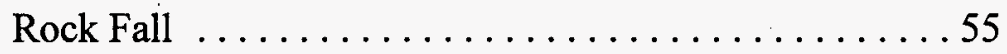

Landslides .........................59

Slumping and Sloughing $\ldots \ldots \ldots \ldots \ldots \ldots \ldots 59$

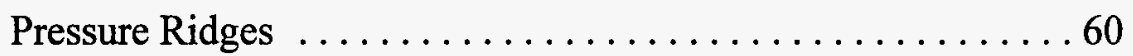

Disturbed Ground . . . . . . . . . . . . . . . . . . . . 60

Hydrologic Effects ......................... 69

Geomorphologic Influences ................6 69

Collapse Sinks and Depressions $\ldots \ldots \ldots \ldots 70$

Craters ........................ 70

Mass Movement ..................... 71

Faults and Fractures $\ldots \ldots \ldots \ldots \ldots \ldots \ldots 71$

Surface Flow and Spring Discharge . . . . . . 72

Miscellaneous Hydrologic Effects . . . . . . . . . . . . 72

Geysers ....................... 73

Spray Domes $\ldots \ldots \ldots \ldots \ldots \ldots \ldots \ldots 73$

Subsurface Hydrologic Effects $\ldots . . \ldots \ldots \ldots . \ldots 74$ 
This page intentionally left blank. 
C-2.1

C-2.1.1

C-2.1.2

C-2.1.3

C- 2.2

C-2.2.1

C-2.2.2

C-2.2.3

C-2.2.4

C-2.3

C-2.3.1

C-2.3.2

C-2.3.3

C-2.3.4

C- -3.0

C- 4.0

C-5.0

C-5.1

C-5.2

C-5.3

C-5.4

C-6.0

C-6.1

C-6.2

C-7.0

C-7.1

C-7.2

C-8.0

C-8.1

C-8.2

C-8.3

C-8.4

C-9.0

C-9.1

C-9.2

C-9.2.1

C-9.2.2

C-10.0
Pre-test Preparations

131

Field Geologic Mapping Team $\ldots \ldots \ldots \ldots \ldots \ldots \ldots \ldots 131$

Planning and Preparation . . . . . . . . . . . . . . . . . . 131

Pre-test Reconnaissance . . . . . . . . . . . . . . . . . 132

Post-test Field Mapping Considerations $\ldots \ldots \ldots \ldots \ldots \ldots \ldots . \ldots 132$

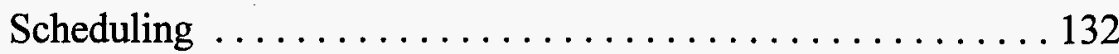

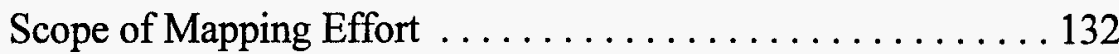

Initial Visual Inspection . . . . . . . . . . . . . . . . . . . . . 132

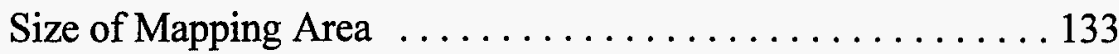

Types of Features Mapped ......................... 133

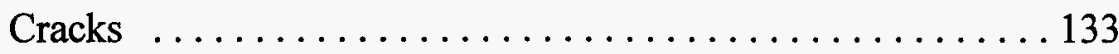

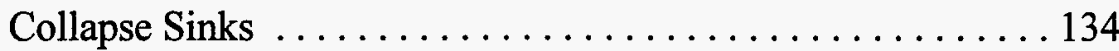

Other Post-shot Surface Effects . . . . . . . . . . . . . . . 134

Definition of Significant Features . . . . . . . . . . . . . 134

METHOD OF RECORDING SURFACE EFFECTS $\ldots \ldots \ldots \ldots \ldots \ldots 135$

SUPPORT OF OTHER INVESTIGATIONS $\ldots \ldots \ldots \ldots \ldots \ldots \ldots \ldots 137$

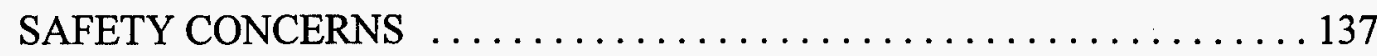

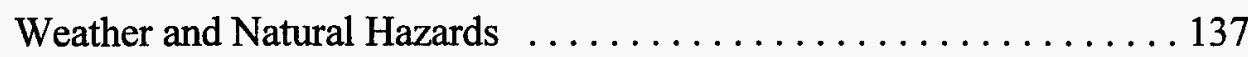

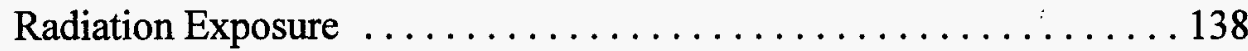

Drilling and Construction Equipment $\ldots \ldots \ldots \ldots \ldots \ldots \ldots \ldots \ldots \ldots$

Surface Collapse ................................... 139

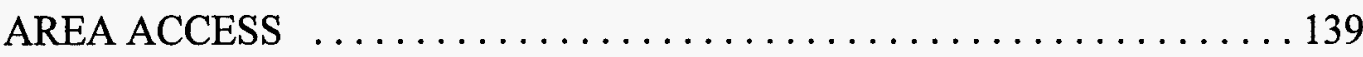

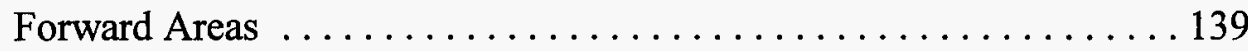

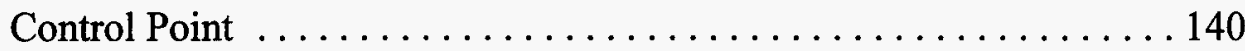

LOGISTICS ................................ 140

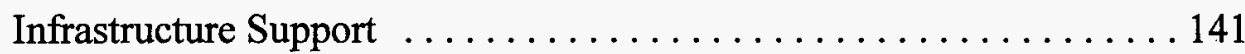

Field Equipment and Materials $\ldots \ldots \ldots \ldots \ldots \ldots \ldots \ldots 14$

REPORTING .................................. 141

Data Compilation and Reduction ...................... 141

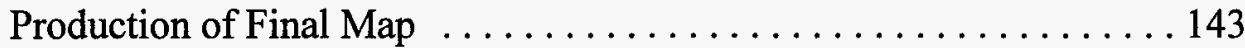

Written Report ............................... 143

Classification Issues . . . . . . . . . . . . . . . . . . . . . . 144

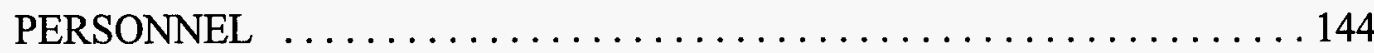

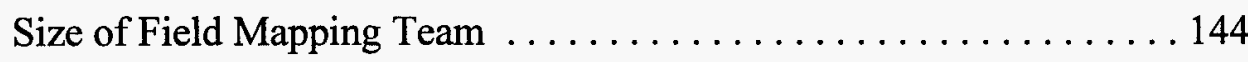

Training Requirements .......................... 144

Skills .................................. 144

Clearances .............................145

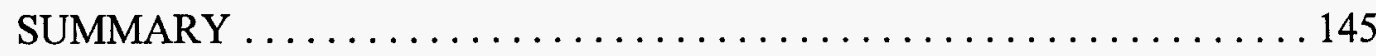




\section{FIGURES}

2-1 Generalized areal distribution of underground nuclear tests conducted

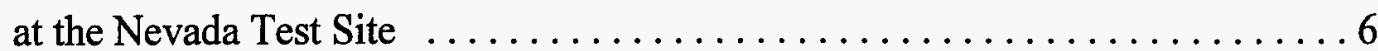

2-2 Schematic illustration of some phenomena associated with an underground

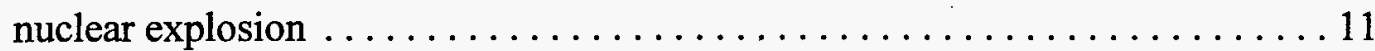

2-3 Generalized gradation in cratering and initial collapse effects resulting from explosions of the same yield at selected depths of burial in alluvium, Nevada Test Site ................................ 12

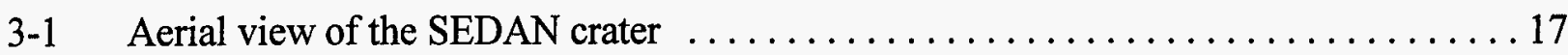

3-2 Schematic illustration of a typical explosion crater (cross-sectional view) . . . . . . . 19

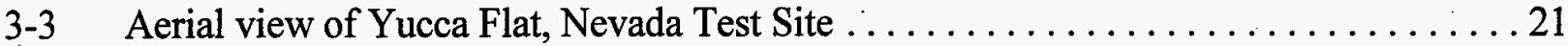

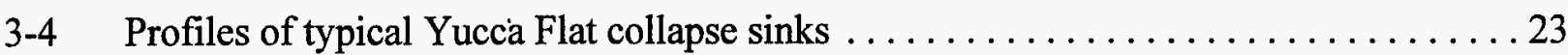

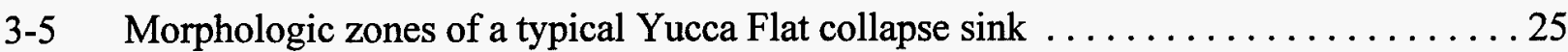

3-6 Crack map of the CARPETBAG test (U2dg) ...................... 30

3-7 Hairline crack in alluvium resulting from the DALHART test $(\mathrm{U} 4 \mathrm{u}) \ldots \ldots \ldots \ldots . \ldots 31$

3-8 Large, spall-enhanced crack along fault trace near the edge of Rainier Mesa . . . . . . 33

3-9 Cracks in prepared surface (trailer park), Rainier Mesa $\ldots \ldots \ldots \ldots \ldots \ldots \ldots \ldots$

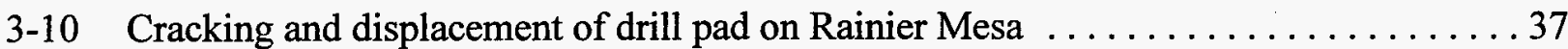

3-11 Crack scar southwest of drillhole U3mq, Yucca Flat ........................ 39

3-12 Revegetated cracks from the CARPETBAG test (U2dg) $\ldots \ldots \ldots \ldots \ldots \ldots \ldots . \ldots 41$

3-13 Test-induced crack developed along pre-existing polygonal mud cracks,

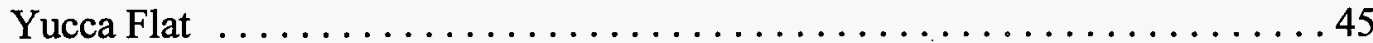

3-14 Explosion-induced displacement along a portion of the Carpetbag Fault, Yucca Flat ................................... 49

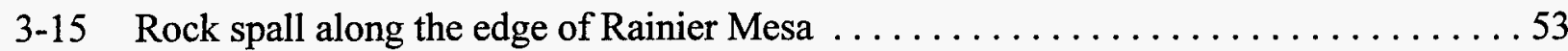

3-16 Rock fall along a prepared surface on Rainier Mesa $\ldots \ldots \ldots \ldots \ldots \ldots \ldots \ldots 7$

3-17 Slump deposits and scars along coastal highlands of Amchitka Island, resulting from the CANNIKIN test $\ldots \ldots \ldots \ldots \ldots \ldots \ldots \ldots \ldots \ldots \ldots \ldots \ldots \ldots \ldots$

3-18 Pressure ridge in alluvium of Yucca Flat, resulting from the

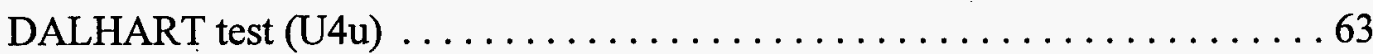

3-19 Large blocks of peat and turf dislodged along fracture zone resulting from

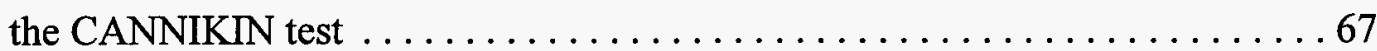

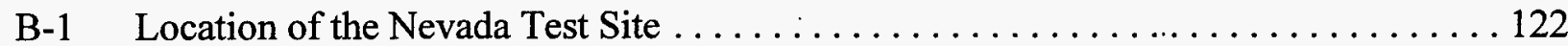

B-2 Generalized geologic map of the Nevada Test Site . . . . . . . . . . . . . . 125 


\section{TABLES}

2-1 Information summary of Nevada Test Site underground nuclear tests $\ldots \ldots \ldots \ldots \ldots$

2-2 Information summary of non-Nevada Test Site underground nuclear tests (U.S.) $\ldots \ldots 7$

3-1 Summary of effects/phenomena and related ecological impacts observed after

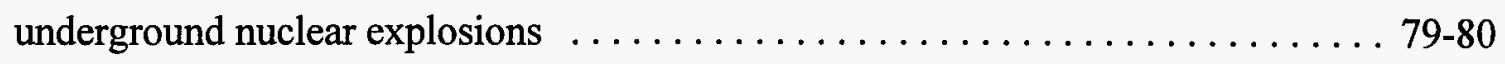

4-1 Geologic surface effects that have natural counterparts $\ldots \ldots \ldots \ldots \ldots \ldots \ldots$

4-2. Possible indicators of the relative age of geologic surface effects . . . . . . . . . 92

C-1 Symbols used to designate surface effects on maps and aerial photos $\ldots \ldots \ldots \ldots 136$

C-2 Field equipment and materials used for surface-effects mapping $\ldots \ldots \ldots \ldots \ldots 142$ 
This page intentionally left blank. 


\section{ACKNOWLEDGMENTS}

The authors gratefully acknowledge the contributions to this report made by others. First and foremost, we thank Ward Hawkins (LANL) for his guidance, support, and patience. Thoughtful reviews of this document were done by Ward Hawkins (LANL), Gayle Pawloski (LLNL), Barbara Harris-West (DSWA) and Dr. Byron Ristvet (DSWA). Loretta Bush from the Department of Energy's Technical Information Resource Center was invaluable in locating and making available reference materials. We also thank Barbara Harris-West (DSWA) and Pat Sanchez (BN Photo Lab) for allowing us to use many of the photos included in this report. Like most compilation works, this report relies heavily on the accounts of previous work by others. This report would not have been possible without the efforts of the many individuals and organizations involved in the documentation and study of surface effects throughout the history of underground nuclear testing. 
This page intentionally left blank. 


\subsection{INTRODUCTION}

The effects of nuclear explosions have been observed and studied since the first nuclear test (code named "Trinity") on July 16, 1945. Since that first detonation, 1,053 nuclear tests have been conducted by the United States, most of which were sited underground at the Nevada Test Site (NTS) (DOE, 1994). The effects of underground nuclear explosions (UNEs) on their surroundings have long been the object of much interest and study, especially for containment, engineering, and treaty verification purposes. One aspect of these explosion-induced phenomena is the disruption or alteration of the near-surface environment, also known as surface effects.

This report was prepared at the request of the Los Alamos National Laboratory (LANL), to bring together, correlate, and preserve information and techniques used in the recognition and documentation of surface effects of UNEs. This report has several main sections, including pertinent background information (Section 2.0), descriptions of the different types of surface effects (Section 3.0), discussion of their application and limitations (Section 4.0), an extensive bibliography and glossary (Section 6.0 and Appendix A), and procedures used to document geologic surface effects at the NTS (Appendix C). Because a majority of U.S. surface-effects experience is from the NTS, an overview of pertinent NTS-specific information also is provided in Appendix B. It is not within the scope of this report to explore new relationships among test parameters, physiographic setting, and the types or degree of manifestation of surface effects, but rather to compile, summarize, and capture surface-effects observations and interpretations, as well as documentation procedures and the rationale behind them.

Documentation of surface effects historically was performed by a small (and now rapidly shrinking) cadre of scientists. This documentation is valuable for many applications, especially archival and test-readiness efforts. In addition, surface-effects information is applicable to the development and verification of UNE (testing) treaties. The importance of these objectives necessitates a firm understanding of surface effects, including the level of effort and expertise needed to fully document them, and the inherent limitations associated with conclusions or interpretations based on their presence and/or nature. 
This page intentionally left blank. 


\subsection{BACKGROUND INFORMATION}

\subsection{U.S. UNDERGROUND NUCLEAR TESTING}

The first U.S. underground nuclear detonation was UNCLE, a test conducted at the NTS in 1951. The first "deep" underground test was in 1957 (PASCAL-A), detonated at a depth of $152 \mathrm{~m}$ (499 $\mathrm{ft}$ ) in an uncased, unstemmed borehole. Since July 17, 1962, all nuclear tests conducted at the NTS have been underground; and in accordance with the Limited Test Ban Treaty (LTBT) of 1963, all subsequent U.S. nuclear tests conducted anywhere have been underground. The Threshold Test Ban Treaty (TTBT) of 1974 limited weapons tests by the United States and the former Soviet Union to yields of no greater than 150 kilotons (kt), and restricted tests to designated test sites (e.g., the NTS for U.S. tests). In addition, these two countries agreed to the Peaceful Nuclear Explosions Treaty (PNET) of 1976, restricting individual peaceful nuclear explosions to yields of no greater than $150 \mathrm{kt}$, and group detonations to aggregate yields of no more than $1500 \mathrm{kt}$. A moratorium on U.S. nuclear testing has been in place since 1992, and the multilateral Comprehensive Test Ban Treaty (CTBT) was signed in 1996.

Information released by the U.S. Department of Energy (DOE) indicates that yields of individual U.S. underground detonations have ranged from "zero" to "less than five megatons" (DOE, 1994). The highest yield of any underground nuclear test ever conducted by the U.S. was CANNIKIN, detonated beneath Amchitka Island, Alaska in 1971. The largest underground tests at the NTS were conducted on Pahute Mesa (prior to compliance with the TTBT). A total of 19 high-yield (greater than or equal to $200 \mathrm{kt}$ ) detonations were conducted here prior to 1977 , several of which had yields that approached or exceeded one megaton (MT). It should be noted that some underground tests consisted of two or more simultaneous (or nearly so) detonations, conducted within the same or separate boreholes or tunnel drifts.

\subsection{THE NEVADA TEST SITE}

Originally known as the "Nevada Proving Ground," the NTS was established in 1951 as a continental location for testing nuclear devices. The NTS has hosted a total of 928 nuclear tests, of which 828 were conducted underground (DOE, 1994). This large and varied experience base has resulted in a great deal of information and knowledge of surface effects. 


\subsubsection{NTS Test Areas}

Most NTS underground nuclear detonations were conducted in three main test areas: 1) Yucca Flat, 2) Pahute Mesa, and 3) Rainier Mesa (including Aqueduct Mesa). Underground tests conducted in Yucca Flat and Pahute Mesa typically were emplaced in vertical drill holes, whereas almost all tests conducted in Rainier Mesa were tunnel emplacements. A total of 85 underground tests (85 detonations) were conducted on Pahute Mesa, including about 19 highyield detonations (200 kt or more). Rainier Mesa hosted 61 underground tests (62 detonations), almost all of which were relatively low-yield (generally less than $20 \mathrm{kt}$ ) tunnel-based weaponseffects tests. Yucca Flat was the most extensively utilized test area, hosting 658 underground tests (747 detonations); four of which were high-yield detonations.

In addition to the three main test areas, underground nuclear tests were conducted in Frenchman Flat (ten tests), Shoshone Mountain (six tests), the Oak Spring Butte/Climax Mine area (three tests), the Buckboard Mesa area (three tests), and Dome Mountain (one test with five detonations). It should be noted that these totals include ten cratering tests (14 total detonations) conducted in various areas of the NTS. Table 2-1 is a synopsis of information about each of the underground test areas at the NTS, and Figure 2-1 is a map showing the areal distribution of underground nuclear tests conducted at the NTS.

The climatic, geologic, hydrogeologic, and physiographic setting of the NTS (Appendix B) has allowed the testing community to conduct a large number and wide assortment of underground nuclear tests in a cost-effective and safe manner, utilizing multiple emplacement methods and configurations, in a variety of test media. More than a remote, sparsely populated location, the NTS is a proven national resource and historically significant asset.

\subsection{OTHER LOCATIONS OF U.S. UNDERGROUND NUCLEAR TESTS}

Although most UNE's were conducted at the NTS, 11 tests (13 total detonations) were conducted elsewhere within the United States. Test locations outside the boundaries of the NTS include sites in New Mexico, Colorado, Mississippi, Alaska, and northern and central Nevada. Tests at these locations encompassed a wide variety of purposes, designs, and yields, and were conducted in an assortment of physiographic settings. Table 2-2 is a listing of all U.S. underground test locations outside the NTS, along with general information about each test. 
Table 2-1. Information summary of Nevada Test Site underground nuclear tests.

\begin{tabular}{|c|c|c|c|c|c|c|c|c|}
\hline $\begin{array}{l}\text { Physiographic } \\
\text { Area }\end{array}$ & $\begin{array}{l}\text { NTS } \\
\text { Area(s) }\end{array}$ & $\begin{array}{l}\text { Total } \\
\text { tests }\end{array}$ & $\begin{array}{l}\text { nderground' } \\
\text { detonations }\end{array}$ & Test dates $^{1}$ & $\begin{array}{c}\text { Announced } \\
\text { high/low } \\
\text { yield range } \\
\text { (kiloton [kt]) } \\
\end{array}$ & $\begin{array}{l}\text { Depth of } \\
\text { burial range }\end{array}$ & $\begin{array}{l}\text { Overburden } \\
\text { media }\end{array}$ & Comments \\
\hline Yucca Flat & $\begin{array}{l}1,2,3 \\
4,6,7 \\
8,9,10\end{array}$ & 658 & 747 & $1957-1992$ & zero/200 to 500 & $\begin{array}{l}27-1219 m \\
(89-3999 f t)\end{array}$ & $\begin{array}{l}\text { Alluvium/Playa } \\
\text { Volcanic Tuff } \\
\text { Paleozoic rocks }\end{array}$ & $\begin{array}{l}\text { Various test types and yields; almost all were } \\
\text { vertical emplacements above and below static } \\
\text { water level. }\end{array}$ \\
\hline Pahute Mesa & 19,20 & 85 & 85 & 1966 - 1992 & $2.3 />1000$ & $\begin{array}{l}31-1452 \mathrm{~m} \\
(100-4765 \mathrm{ft})\end{array}$ & $\begin{array}{l}\text { Alluvium (thin) } \\
\text { Volcanic tuffs \& } \\
\text { lavas }\end{array}$ & $\begin{array}{l}\text { Almost all were large-diameter vertical } \\
\text { emplacements above and below static water } \\
\text { level; includes } 19 \text { high-yield detonations. }\end{array}$ \\
\hline $\begin{array}{l}\text { Rainier/ } \\
\text { Aqueduct Mesa }\end{array}$ & 12 & 61 & 62 & $1958-1992$ & $\begin{array}{l}\text { zero/20 to } 200 \\
\text { (most }<20)\end{array}$ & $\begin{array}{c}61-640 \mathrm{~m} \\
(200-2100 \mathrm{ft})\end{array}$ & $\begin{array}{l}\text { Tuffs with welded } \\
\text { tuff caprock } \\
\text { (little or no } \\
\text { alluvium) }\end{array}$ & $\begin{array}{l}\text { Two vertical emplacements; all others were } \\
\text { horizontal tunnel emplacements above static } \\
\text { water level; mostly low-yield Department of } \\
\text { Defense weapons-effects tests. }\end{array}$ \\
\hline Frenchman Flat & 5,11 & 10 & 10 & $1965-1971$ & $<20$ & $\begin{array}{l}179-296 m \\
(587-971 \mathrm{ft})\end{array}$ & $\begin{array}{l}\text { Mostly alluvium } \\
\text { minor volcanics }\end{array}$ & $\begin{array}{l}\text { Various emplacement configurations, both } \\
\text { above and below static water level. }\end{array}$ \\
\hline Shoshone Mtn. & 16 & 6 & 6 & $1962-1971$ & $\mid 0 w /<20$ & $\begin{array}{l}244-640 \mathrm{~m} \\
(800-2100 \mathrm{ft})\end{array}$ & Bedded Tuff & $\begin{array}{l}\text { Tunnel-based low-yield weapons-effects and } \\
\text { Vela Uniform tests. }\end{array}$ \\
\hline $\begin{array}{l}\text { Oak Spring } \\
\text { Butte } \\
\text { (Climax Area) }\end{array}$ & 15 & 3 & 3 & $1962-1966$ & $5.7 / 62$ & $\begin{array}{l}229-351 \mathrm{~m} \\
(750-1150 \mathrm{ft})\end{array}$ & Granite & $\begin{array}{l}\text { Three tunnel-based tests above static water } \\
\text { level. (HARD HAT, TINY TOT, and PILE } \\
\text { DRIVER). }\end{array}$ \\
\hline $\begin{array}{l}\text { Buckboard } \\
\text { Mesa }\end{array}$ & 18 & 3 & 3 & $1962-1964$ & $0.092 / 0.5$ & $\begin{array}{l}\leq 27 \mathrm{~m} \\
(90 \mathrm{ft})\end{array}$ & Basaltic Lavas & $\begin{array}{l}\text { Shallow, low-yield cratering experiments } \\
\text { (SULKY, JOHNNIE BOY² and DANNY BOY); all } \\
\text { were above static water level. }\end{array}$ \\
\hline Dome Mountain & 30 & 1 & 5 & $03 / 12 / 68$ & $\begin{array}{l}\text { five detonations } \\
@ 1.08 \mathrm{kt} \text { each }\end{array}$ & $\begin{array}{l}50 \mathrm{~m} \\
(165 \mathrm{ft})\end{array}$ & Mafic Lava & $\begin{array}{l}\text { BUGGY (A, B, C, D, and E); Plowshare cratering } \\
\text { test of five-shot horizontal salvo; all above static } \\
\text { water level. }\end{array}$ \\
\hline
\end{tabular}

1 Source: U.S. Department of Energy (1994)

2 JOHNNIE BOY was detonated at a depth of $1.75 \mathrm{ft}$ (essentially a surface burst) approximately one mile east of Buckboard Mesa. 


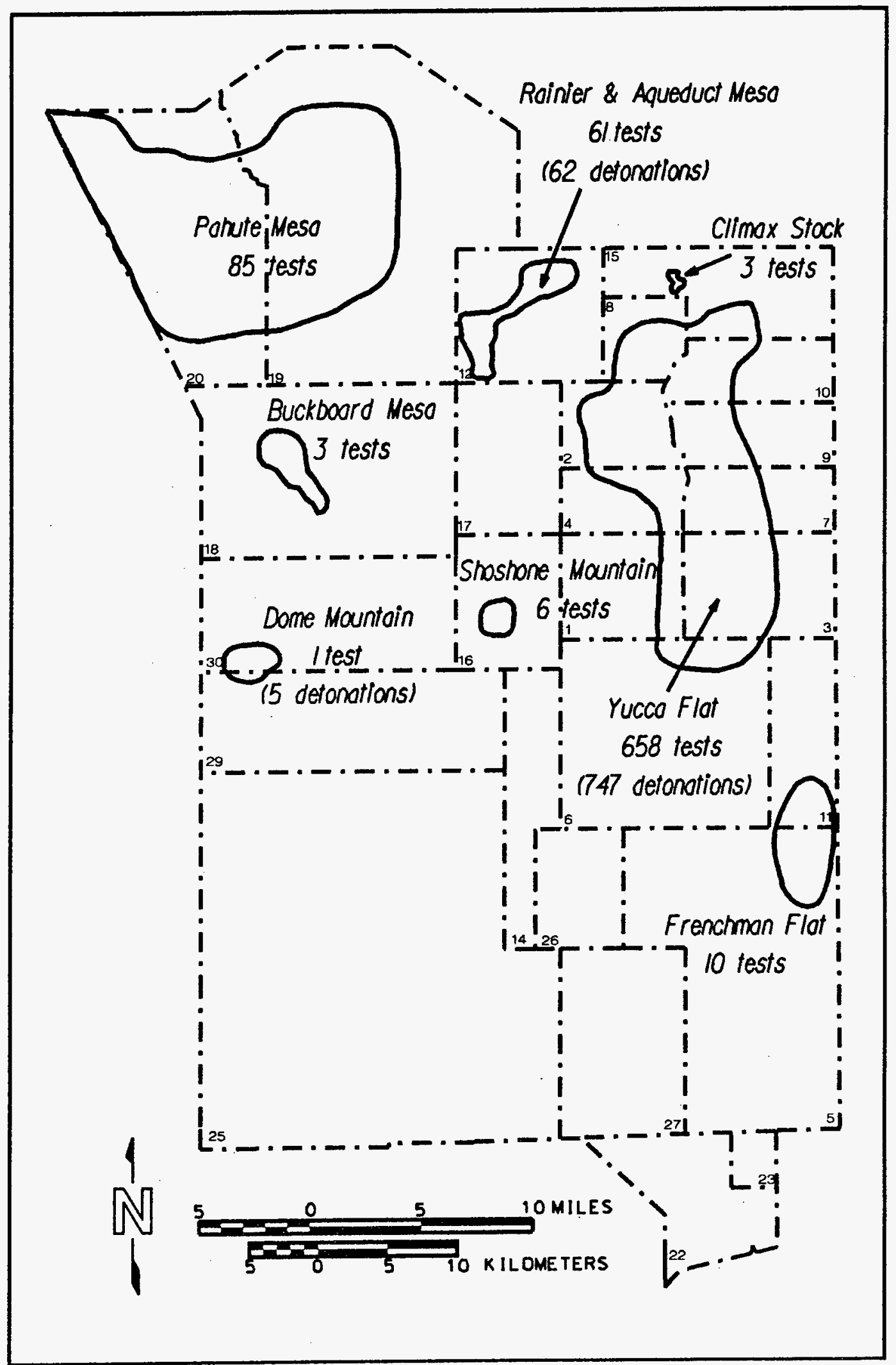

Figure 2-1. Generalized areal distribution of underground nuclear tests conducted at the Nevada Test Site. 
Table 2-2. Information summary of non-Nevada Test Site underground nuclear tests (U.S.).

\begin{tabular}{|c|c|c|c|c|c|c|c|}
\hline Test' & Location ${ }^{1}$ & $\begin{array}{l}\text { Test } \\
\text { date }^{1}\end{array}$ & $\begin{array}{l}\text { Yield } \\
(\mathbf{k t})^{1}\end{array}$ & $\begin{array}{l}\text { Depth of } \\
\text { burial } \\
\text { m (ft) }\end{array}$ & Overburden medium & Test type and comments & References \\
\hline GNOME & $\begin{array}{l}\text { Carlsbad, } \\
\text { New Mexico }\end{array}$ & $12 / 10 / 61$ & 3 & $366(1200)$ & $\begin{array}{l}\text { Sands and gravels } \\
\text { bedded salt }\end{array}$ & $\begin{array}{l}\text { Plowshare; vertical shaft to horizontal } \\
\text { experiment drift in bedded salt. }\end{array}$ & $\begin{array}{l}\text { Cooper \& Glanzman, 1971; } \\
\text { Gard, 1963; } \\
\text { Swift, } 1963\end{array}$ \\
\hline GASBUGGY & $\begin{array}{l}\text { Farmington, } \\
\text { New Mexico }\end{array}$ & $12 / 10 / 67$ & 29 & $1292(4240)$ & Shale & $\begin{array}{l}\text { Plowshare; gas-recovery experiment in } \\
\text { San Juan Basin. }\end{array}$ & $\begin{array}{l}\text { Holzer, 1968; } \\
\text { Foote, Hays, \& Klepinger, } 1969\end{array}$ \\
\hline SHOAL & $\begin{array}{l}\text { Fallon, } \\
\text { Nevada }\end{array}$ & $10 / 26 / 63$ & 12 & $402(1320)$ & Granite & Vela Uniform test; shaft emplacement. & USDOE, 1984 \\
\hline FAULTLESS & $\begin{array}{l}\text { Central } \\
\text { Nevada }\end{array}$ & $01 / 19 / 68$ & $\begin{array}{c}200 \text { to } \\
1000\end{array}$ & $975(3200)$ & $\begin{array}{l}\text { Alluvium } \\
\text { tuffaceous sediments } \\
\text { zeolitized tuff }\end{array}$ & Ground-motion/seismic calibration test. & $\begin{array}{l}\text { McKeown, Dickey, \& Ellis, 1968; } \\
\text { Tueller, Bruner, \& Davis, 1972; } \\
\text { Tueller, et al., 1974; } \\
\text { Thordarson, } 1985\end{array}$ \\
\hline RULISON & $\begin{array}{l}\text { Grand Valley, } \\
\text { Colorado }\end{array}$ & $09 / 10 / 69$ & 40 & $2568(8426)$ & $\begin{array}{l}\text { Interbedded sandstone } \\
\& \text { shale }\end{array}$ & $\begin{array}{l}\text { Plowshare; gas-recovery enhancement } \\
\text { experiment in Piceance Creek Basin. }\end{array}$ & ERC, 1970a; 1970b \\
\hline $\begin{array}{l}\text { RIO } \\
\text { BLANCO }\end{array}$ & $\begin{array}{l}\text { Rifle, } \\
\text { Colorado }\end{array}$ & $05 / 17 / 73$ & $\begin{array}{l}\text { three @ } \\
33 \mathrm{kt} \\
\text { each }\end{array}$ & $\begin{array}{l}1780(5839) \\
1899(6230) \\
2039(6690)\end{array}$ & $\begin{array}{l}\text { Interbedded sandstone } \\
\& \text { shale }\end{array}$ & $\begin{array}{l}\text { Plowshare; vertical-salvo detonation of } \\
\text { three devices; gas-recovery } \\
\text { enhancement experiment. }\end{array}$ & $\begin{array}{l}\text { Whicker, Alldredge, \& Hanson, 1973; } \\
\text { CER Geonuclear, } 1971\end{array}$ \\
\hline SALMON & $\begin{array}{l}\text { Hattiesburg, } \\
\text { Mississippi }\end{array}$ & $10 / 22 / 64$ & 5.3 & $828(2717)$ & $\begin{array}{l}\text { Salt dome overlain by } \\
\text { unconsolidated clays, } \\
\text { silts, and sands }\end{array}$ & Vela Uniform test. & $\begin{array}{l}\text { Humphreys \& Taylor, 1965; } \\
\text { USAEC, } 1967\end{array}$ \\
\hline STERLING & $\begin{array}{l}\text { Hattiesburg, } \\
\text { Mississippi }\end{array}$ & $12 / 03 / 66$ & 0.38 & $828(2717)$ & same as SALMON & $\begin{array}{l}\text { Vela Uniform test; detonated in cavity } \\
\text { produced by SALMON test. }\end{array}$ & Davis, 1968 \\
\hline LONG SHOT & $\begin{array}{l}\text { Amchitka } \\
\text { Island, } \\
\text { Alaska }\end{array}$ & $10 / 29 / 65$ & $\sim 80$ & $701(2300)$ & $\begin{array}{l}\text { Andesitic pillow lavas \& } \\
\text { volcanic breccias; } \\
\text { tundra at surface }\end{array}$ & Vela Uniform test. & $\begin{array}{l}\text { Everett \& Amundsen, 1975; } \\
\text { McKeown, et al., } 1967\end{array}$ \\
\hline MILROW & $\begin{array}{l}\text { Amchitka } \\
\text { Island, } \\
\text { Alaska }\end{array}$ & $10 / 02 / 69$ & $\sim 1000$ & $1218(3996)$ & $\begin{array}{l}\text { Andesitic pillow lavas \& } \\
\text { volcanic breccias; } \\
\text { tundra at surface }\end{array}$ & Calibration test for CANNIKIN test. & $\begin{array}{l}\text { Everett \& Amundsen, 1975; } \\
\text { Koh \& Rosencrantz, 1970; } \\
\text { USGS, 1970; } \\
\text { Wright, 1971a; 1971b }\end{array}$ \\
\hline CANNIKIN & $\begin{array}{l}\text { Amchitka } \\
\text { Island, } \\
\text { Alaska }\end{array}$ & $11 / 06 / 71$ & $<5000$ & $1792(5879)$ & $\begin{array}{l}\text { Andesitic pillow lavas \& } \\
\text { volcanic breccias; } \\
\text { tundra at surface }\end{array}$ & $\begin{array}{l}\text { Detonated in } 15.8 \mathrm{~m} \text { diameter chamber; } \\
\text { largest U.S. underground test. }\end{array}$ & $\begin{array}{l}\text { Everett \& Amundsen, 1975; } \\
\text { Gonzalez \& Wollitz, 1972, 1974; } \\
\text { Morris, Gard, \& Snyder, 1972; } \\
\text { Morris, 1973; Kirkwood \& Fuller, 1972; } \\
\text { USGS, 1972;1974 }\end{array}$ \\
\hline
\end{tabular}




\subsection{PHENOMENOLOGY OF UNDERGROUND NUCLEAR EXPLOSIONS}

A wide variety of surface effects has been observed following underground nuclear tests. These effects differ in both character and magnitude, depending on numerous factors. In simplistic terms, these factors include (1) how much energy is released, or the explosive "yield" of the device; (2) the depth of burial (DOB) of the device; (3) how well the energy of the explosion is transmitted to the earth's surface; and 4) how this energy interacts with material at the surface. Yield and DOB of the test are the most straightforward variables, and often are expressed together as the scaled depth of burial (SDOB), usually in the form of meters per kiloton ${ }^{1 / 3}$ $\left(\mathrm{m} / \mathrm{kt}{ }^{1 / 3}\right)$. The propagation of energy to the surface is more complicated, and is influenced initially by how well the energy from the explosion couples with the earth surrounding it, as well as the explosive yield. Coupling in turn is dependent primarily on the configuration of the test (size and shape of any voids around device), and the characteristics of the working point medium (strength, density, water content, and any shock effects from previous tests). As the energy propagates through the earth, its path and characteristics are influenced greatly by the nature of the overburden. At the surface, this energy is translated into several types of motion, resulting in various levels of stress in the near-surface environment. This stress can in turn physically disrupt or alter the near surface in numerous and diverse ways, again depending greatly on the nature of the material being affected.

To better understand the surface effects caused by UNEs, it is important first to have a firm grasp of the fundamentals of the processes that occur as a result of these tests. Because many of the phenomena associated with UNEs are unique, it is worthwhile to summarize the present understanding of these processes. The following is a simplified synopsis of the phenomenology of a UNE, as it is currently understood and accepted. This synopsis is generalized mostly from the early work of Johnson and Violet (1958), Eisler and Chilton (1964), Germain and Kahn (1968), Rodean (1970), Boardman (1970), Higgins (1970), Hakala (1970), Glasstone and Dolan (1977), and more recent summaries by the U.S. Congress (1989), Kunkle (1994), and Carothers, et al., (1995).

Within a microsecond after detonation, a nuclear explosion releases the energy of billions of atoms, mostly in the form of X-rays and neutrons. This energy instantly vaporizes the device and the material immediately surrounding it. The vapor expands rapidly, driving a strong shock wave outward from the detonation. This intense shock wave in turn vaporizes and melts more rock, forming a region of intense heat and pressure. The driving force of the high-pressure gases, 
and the momentum imparted by the shock wave combine to produce a more or less spherical cavity region. Cavity expansion begins rapidly, then slows and stops as pressures within the region decrease to levels comparable with the confining stress of the surrounding material. The cavity walls then rebound slightly, creating residual compressive stresses (circumferential or "hoop" stresses) around the cavity. These compressive stresses form a "containment cage" around the cavity, which acts to prevent and/or close hydraulic fractures in the test media, holding gases within the cavity.

Meanwhile, the shock wave moves out beyond the cavity region, crushing and deforming the surrounding rock inelastically, and weakening as it travels outward from the explosion. As the energy of the shock wave decays further, the response of the surrounding material changes from an inelastic to elastic behavior, resulting in seismic waves. At sufficiently small SDOBs, the shock wave reaches the surface (followed by the seismic wave train), producing an upward acceleration of the ground surface which results in a temporary (usually) dome-like expansion or uplift of the ground surface above the working point. Some of the energy of the shock wave is then reflected back into the subsurface as a rarefaction or tensional stress wave. At some depth, the energy of this descending stress wave exceeds the sum of the remaining energy of the ascending stress wave train, the overburden stress, and the tensile strength of the rock. At this depth, the layers of earth can separate or part along naturally occurring planes of weakness, a phenomenon known as spall. The spalled layers move ballistically upward, eventually falling back downward and impacting the adjacent layers below (also known as spall closure or "slapdown"). The areal and vertical extent of spallation, or the "spall region," is strongly influenced by the SDOB, the geologic and hydrogeologic setting, and local topography. Surface cracks and compaction of overburden strata are most common in this region.

A few seconds after detonation, molten rock begins to collect and solidify into a puddle of glass at the bottom of the cavity. This material contains most of the radioactive products from the explosion. Cavity gases begin to cool and condense, causing the pressure within the cavity to decrease. At some point, ranging from minutes to days after detonation, the cavity walls collapse and the unsupported overlying rock falls into the cavity below as rubble, which quickly condenses any remaining steam within the cavity. As the overlying rock falls downward, the void region stopes upward, forming a roughly cylindrical collapse column or "chimney" above the cavity region. This chimneying process continues until (1) the void within the chimney completely fills with rubble; (2) the chimney reaches a level where the shape of the void region and the strength of the rock can support the overburden material; or (3) the chimney and void 
region reaches the surface, resulting in a collapse of the ground surface. In the first two scenarios, there may be little or no surface evidence of the chimney or void. If the chimney/void region reaches the surface, however, a collapse sink typically forms. Figure 2-2 is a schematic illustration of some of the underground nuclear test phenomena described.

It should be noted that the phenomena described above are typical of "normal" emplacement configurations that are (1) not decoupled, and (2) "deep" but not "overburied" SDOBs. At shallow DOBs, the force of the detonation may rupture the overburden extensively, forming a rubble mound (as in the case of the SULKY test). At even shallower burst depths, the fireball and/or hot, high-pressure gases generated during the explosion may breach the surface, resulting in an ejecta or throw-out crater at ground level (e.g. SEDAN, DANNY BOY, etc.). Figure 2-3 shows some general relationships between depth of burial and gradations of surface cratering, mounding, and collapse for NTS alluvium.

A UNE can result in appreciable amounts of seismic activity, derived principally from three sources: (1) the explosion itself, (2) the chimneying process, and (3) post-test earthquakes or aftershocks. Most of the seismic energy comes from the explosion itself. Seismic signals from the explosion are an order of magnitude larger than any other source, and often can be detected several thousand kilometers $(\mathrm{km})$ away. It should be noted, however, that only a small portion (less than five percent) of the total energy released by a UNE is translated into seismic waves. Because the strata through which the waves propagate are not homogenous and isotropic, seismic waves are modified extensively through phenomena such as reflection, refraction, diffraction, and wave-mode conversion. In addition, wave energy dissipates through various loss phenomena such as attenuation, geometric spreading, absorption, and scattering. Depending on the timing of collapse, seismic activity associated with chimneying could occur in various stages, and was often monitored and recorded to study the chimneying process and predict surface collapse. Seismic activity from post-test aftershocks has been monitored after many of the high-yield tests, however, these aftershocks or "microquakes" usually are of relatively small magnitude (typically several orders of magnitude less than that of the explosion itself), and generally are limited to upper portions of the crust in the vicinity (within $20 \mathrm{~km}$ ) of the test.

The seismic activity induced by a UNE can result in both permanent and temporary displacements of the earth's surface. These movements can exhibit various frequencies and amplitudes, and are cumulatively known as ground motion. Ground motion typically is 

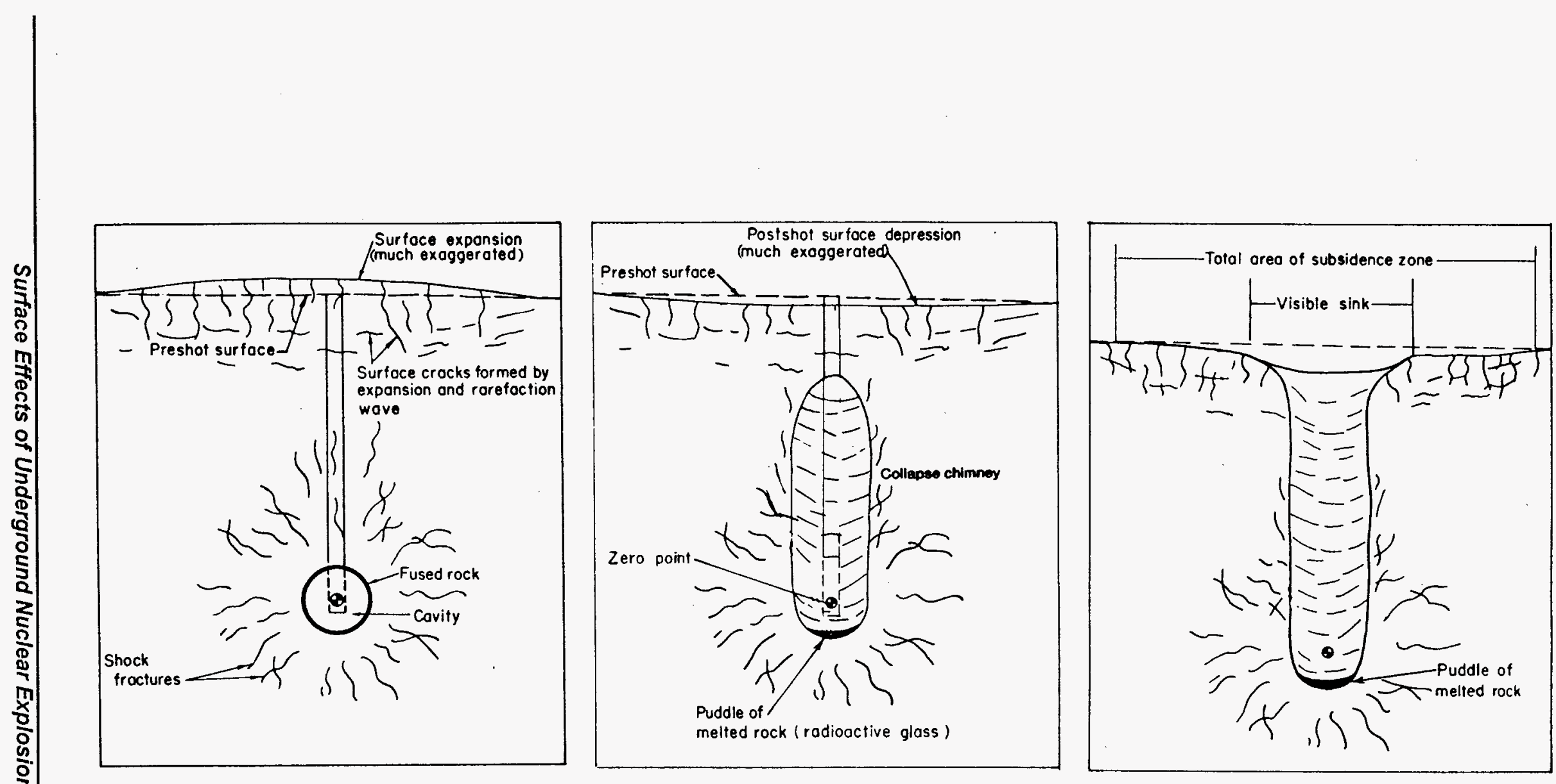

Figure 2-2. Schematic illustration of some phenomena associated with an underground nuclear explosion (adapted from Houser, 1969b). 
Craters

Mounding

Surtace collepeo

nor subeidence

Ittlo or no surteces expreacion

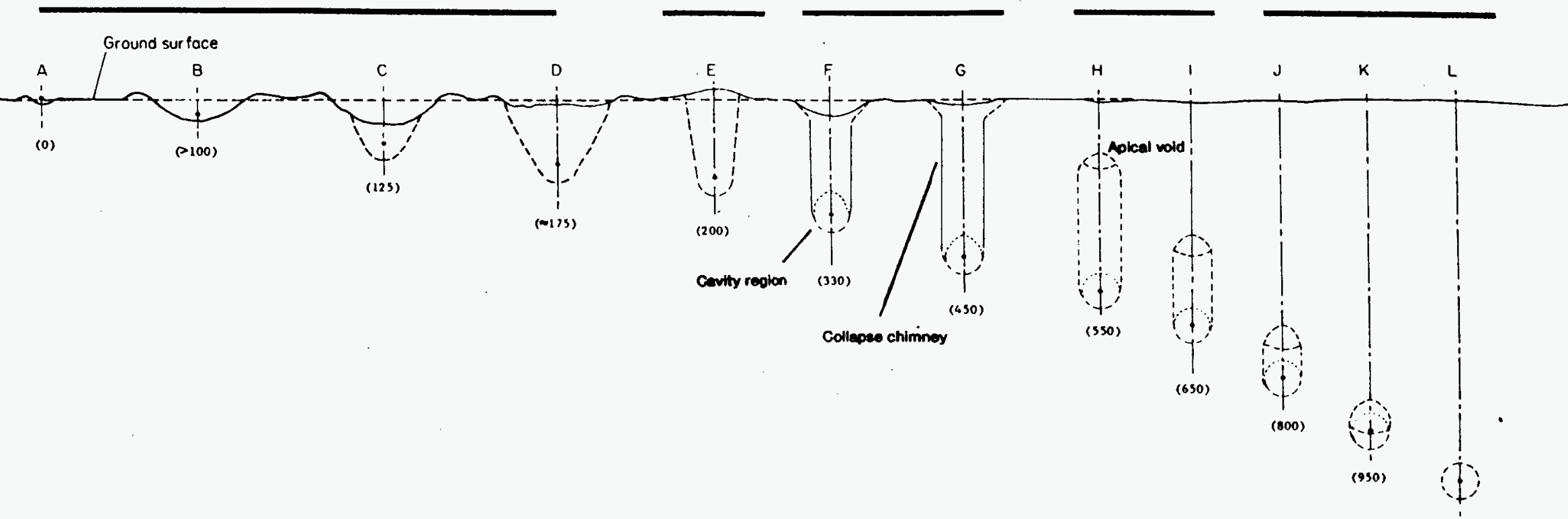

(1,200)

Figure 2-3. Generalized gradation in cratering and initial collapse effects resulting from explosions of the same yield at selected depths of burial in alluvium, Nevada Test Site. Approximate scaled depth of burial ( $W^{1 / 3}$ feet) in parentheses (from Houser, 1970a). 
characterized by measurements of: (1) acceleration, (2) velocity; and (3) displacement. For high-yield tests, ground motion often was quite violent, especially during passage of the initial shock wave. Peak velocities of several meters per second, and peak accelerations of many times the force of gravity commonly were measured (especially within the spall zone) on many highyield tests. High-yield tests also have the potential of producing damaging ground motion for many tens of kilometers from a detonation. In addition, UNE-induced ground motion can initiate pressure pulses in the overlying media, as energy from the explosion is transmitted across the ground-air and/or ground-water interface. This energy can be manifest as damaging air and/or water overpressures in the SGZ vicinity. Consequently, ground motion is the driving force behind both the type and severity of damage exhibited at the surface above a UNE. 
This page intentionally left blank. 


\subsection{TYPES OF SURFACE EFFECTS}

This section presents a brief synopsis of each of the different types of surface effects observed at various test sites. Although these descriptions are heavily influenced by NTS experience, they encompass a wide variety of geologic settings and test parameters, and should be applicable to surface effects evaluations of other test locations. Surface effects are quite diverse, but can be grouped into three main categories: (1) geologic and hydrologic effects, (2) ecological effects, and (3) cultural-feature effects. As stated earlier, the types and magnitude of surface effects from UNEs are quite variable, with some tests resulting in no visible surface effects at all.

\subsection{GEOLOGIC AND HYDROLOGIC EFFECTS}

\subsubsection{Previous Investigations and Documentation Efforts}

Geologic-type surface effects of underground nuclear tests conducted at the NTS have been studied and documented by several different organizations. Personnel from the U.S. Geological Survey (USGS) investigated and documented the surface effects of many tests from the late 1950s to the late 1970s. In 1964, the USGS also began compiling and producing composite surface effects maps for the different test areas at the NTS. Surface effects mapping later became the responsibility of the sponsoring laboratory or agency, specifically: Los Alamos National Laboratory (LANL); Lawrence Livermore National Laboratory (LLNL); and the Defense Nuclear Agency (DNA) and their predecessor organizations. Geologists employed by Raytheon Services Nevada (RSN) and Fenix \& Scisson (F\&S) (both predecessors of Bechtel Nevada) mapped surface effects for all LANL and DNA tests beginning about 1977, and LLNL utilized mostly in-house personnel starting about 1980. The USGS continued its involvement through the compilation and production of composite surface effects maps, and with development and application of photogrammetric mapping techniques (Van de Werken, 1983; Garcia, 1987, 1989; Williams, Garcia, and Covington, 1991). In addition, the USGS was involved in or responsible for documentation of surface effects from U.S. underground tests conducted at non-NTS test locations. 
In an effort to standardize and document the procedures used in mapping surface effects at the NTS, a cooperative procedure study was undertaken by the USGS, F\&S, and LLNL geologists, (Garcia, Drellack, and McKinnis, 1989). To date, this procedure summary has not been finalized or published. This unpublished study, however, along with procedures presented by Drellack (1988) and Baldwin and Townsend (1995) provide the framework upon which mapping procedures described in Appendix $\mathrm{C}$ were developed.

\subsubsection{Craters}

For nuclear testing applications, a crater is defined as a topographic depression caused by an explosion that results in compaction, throw-out, and/or vaporization of earth near the ground surface. Craters can result from detonations at or slightly above the surface, and shallowly buried UNEs. A great deal of experience with craters has been gained through excavation tests conducted as part of the Plowshare Program, a program developed to explore the peaceful uses of nuclear explosions. The largest and perhaps most famous U.S. cratering experiment was the SEDAN test, conducted in 1962 (Figure 3-1). Cratering experience has also been gained from atmospheric testing in the Pacific Proving Grounds during the 1950s (Circeo and Nordyke, 1964), and to a limited extent from atmospheric tests conducted at the NTS. In addition, some information about cratering experience in the former Soviet Union is available (Nordyke, 1975).

Craters represent a small yet highly conspicuous fraction of the surface effects observed at the NTS. Craters are generally circular in plan view, and have a conical profile much like that of a meteorite impact crater. In addition, there usually is displacement of the original ground level around the perimeter of the crater, in the form of an elevated rim or lip which consists of loose ejecta and/or "flaps" of overturned strata . Figure 3-2 shows a typical cross section of an explosion-induced crater. Craters vary in areal size and depth depending primarily on device yield and proximity to ground level, and it should be noted that the true crater boundary (especially the bottom of the crater) is typically obscured by fall-back (ejecta that fell back into the crater).

Because of their proximity to the ground surface, the release of radioactive materials during cratering tests was typical. Following the SCHOONER detonation in 1968 (from which radioactivity was detected outside the boundaries of the NTS), no subsequent U.S. cratering tests were approved, and the Plowshare Program was terminated in the early 1970s. 


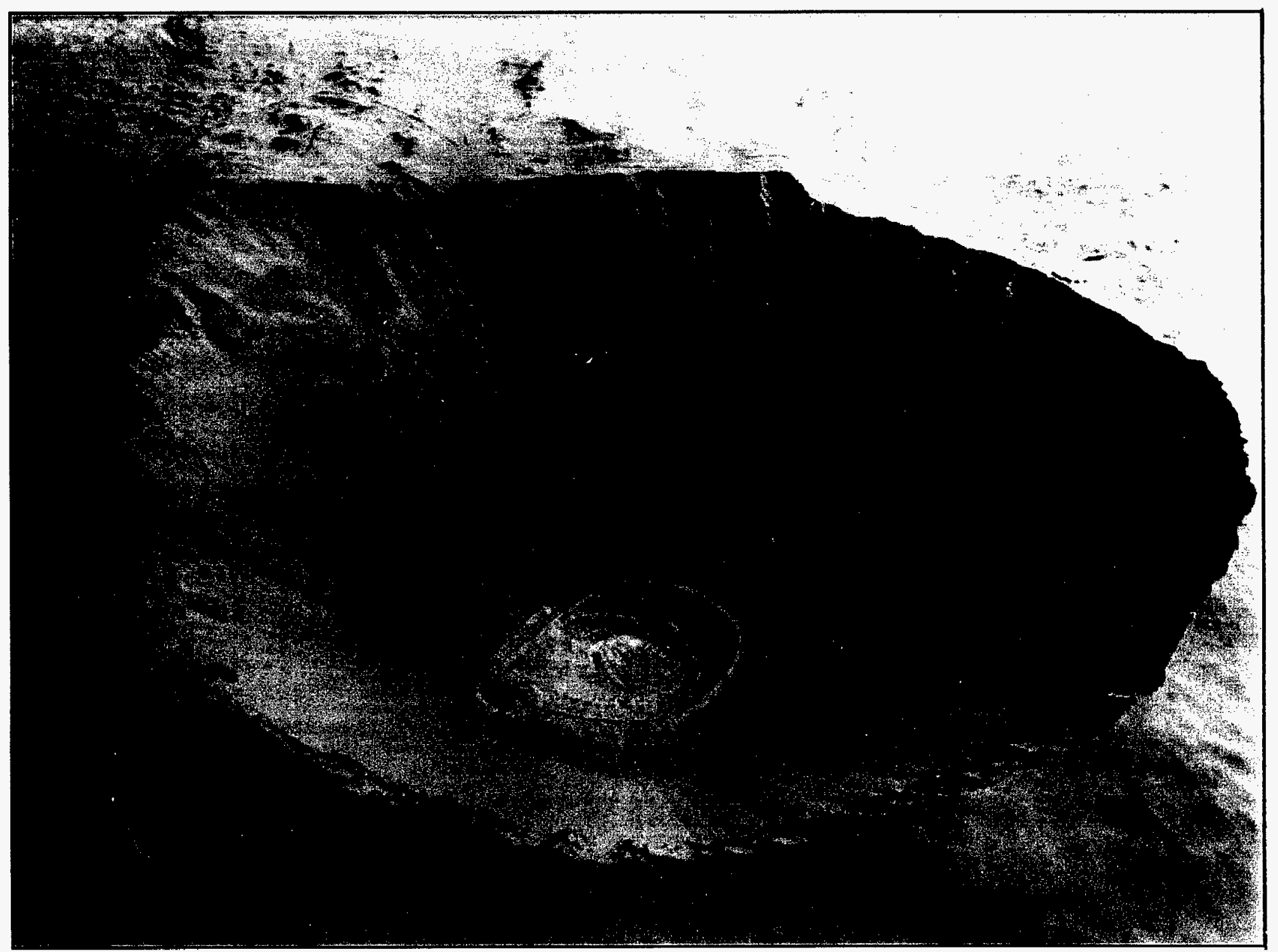

Figure 3-1. Aerial view of the SEDAN crater (note construction equipment at left for scale). 
This page intentionally left blank. 


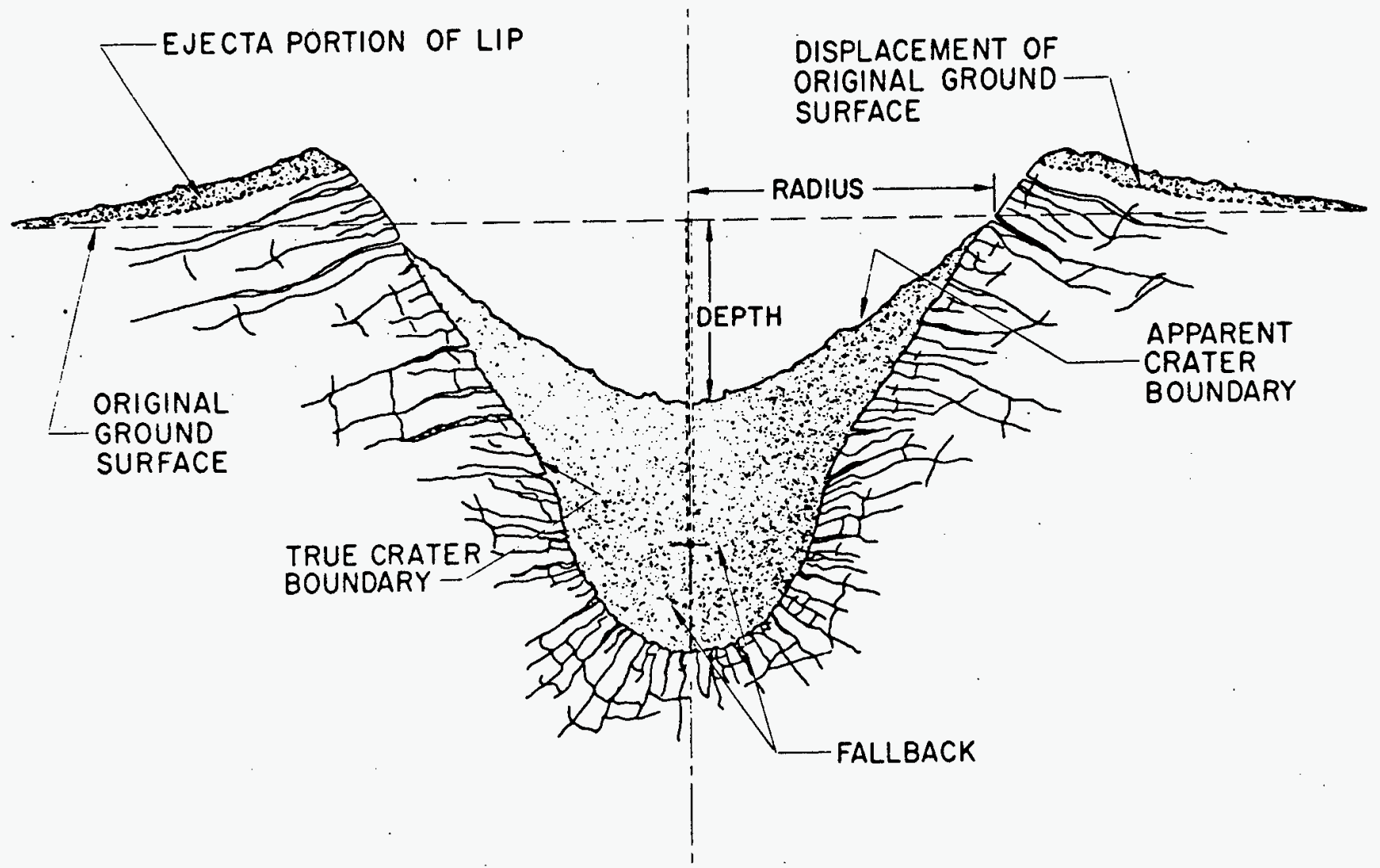

Figure 3-2. Schematic illustration of a typical explosion crater (cross-sectional view) (from Nordyke, 1964). 


\subsubsection{Collapse Sinks}

A collapse sink is a topographic depression caused by the failure and collapse of the ground surface above a UNE cavity. Although craters and sinks are somewhat similar in morphology, the key factor in the formation of a sink is the collapse of underlying strata, rather than a throwout or vaporization of near-surface material. Although the terms crater and sink sometimes are used interchangeably, they denote two genetically different features that should not be confused (Houser and Eckel, 1962).

The first U.S. underground nuclear test to form a collapse sink was the NEPTUNE detonation, conducted at the NTS in 1958. Collapse sinks subsequently became the focus of much interest and study, especially during the late 1960s and early 1970s (Houser, 1969, 1970a, 1970b, 1970c; Ellis and Snyder, 1974). The mechanisms and phenomena related to cavity collapse and subsequent overburden subsidence have been investigated mostly for containment purposes (Jones, 1978; Carroll, 1993; Deupree et al., 1987; Smith, 1970; and Thigpen and Rambo, 1985), but have also been studied for peaceful nuclear explosion (PNE) applications (Hakala, 1968a, $1968 \mathrm{~b}, 1969,1970)$ and for treaty compliance purposes.

Collapse sinks are present in all three main testing areas of the NTS, but are most prevalent and best exhibited in Yucca Flat. Collapse sinks dominate the surface of a large portion of Yucca Flat, often invoking comparisons to a lunar landscape (Figure 3-3). Collapse sinks vary in areal size and shape, and can have distinctly different vertical cross-sectional shapes. A number of factors can influence the size and morphology of a collapse sink, including cavity volume, DOB, overburden geology, the in situ stress field, and topography. Based on careful examination of NTS experience, a number of relationships between experiment parameters, geology, and collapse sink size have been recognized (Kunkle, 1994; Carothers et al., 1995). Research into these relationships has been important in accurately estimating the size of the area around surface ground zero (SGZ) most likely to be affected by collapse, as well as determining when and if collapse will occur.

Sinks are generally cone-shaped in vertical cross section, however several variations of profile shape have been observed at the NTS (Figure 3-4). Examples of these shapes include: "dish" or "dish pan" (CAMPOS); "cookie-cutter"or "posthole" (NEW POINT, GREELEY, LONGCHAMPS, LAGOON, TYG); "bowl" (BANON, ESROM); "bottle-shaped" (DRILL, AGRINI); and "stepped" (CUP). Bottle-shaped collapse sinks seem to be the most rare at the 


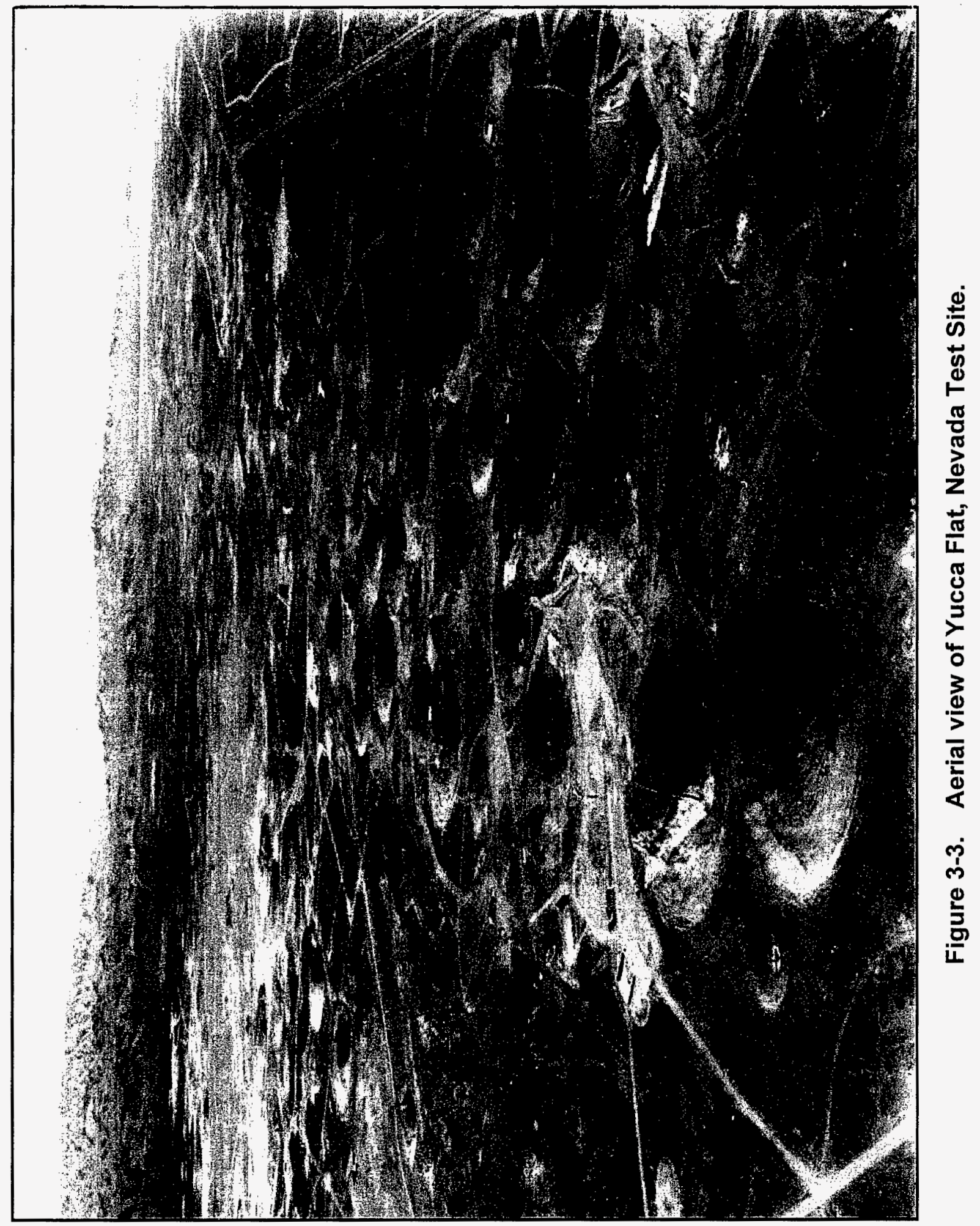


This page intentionally left blank. 

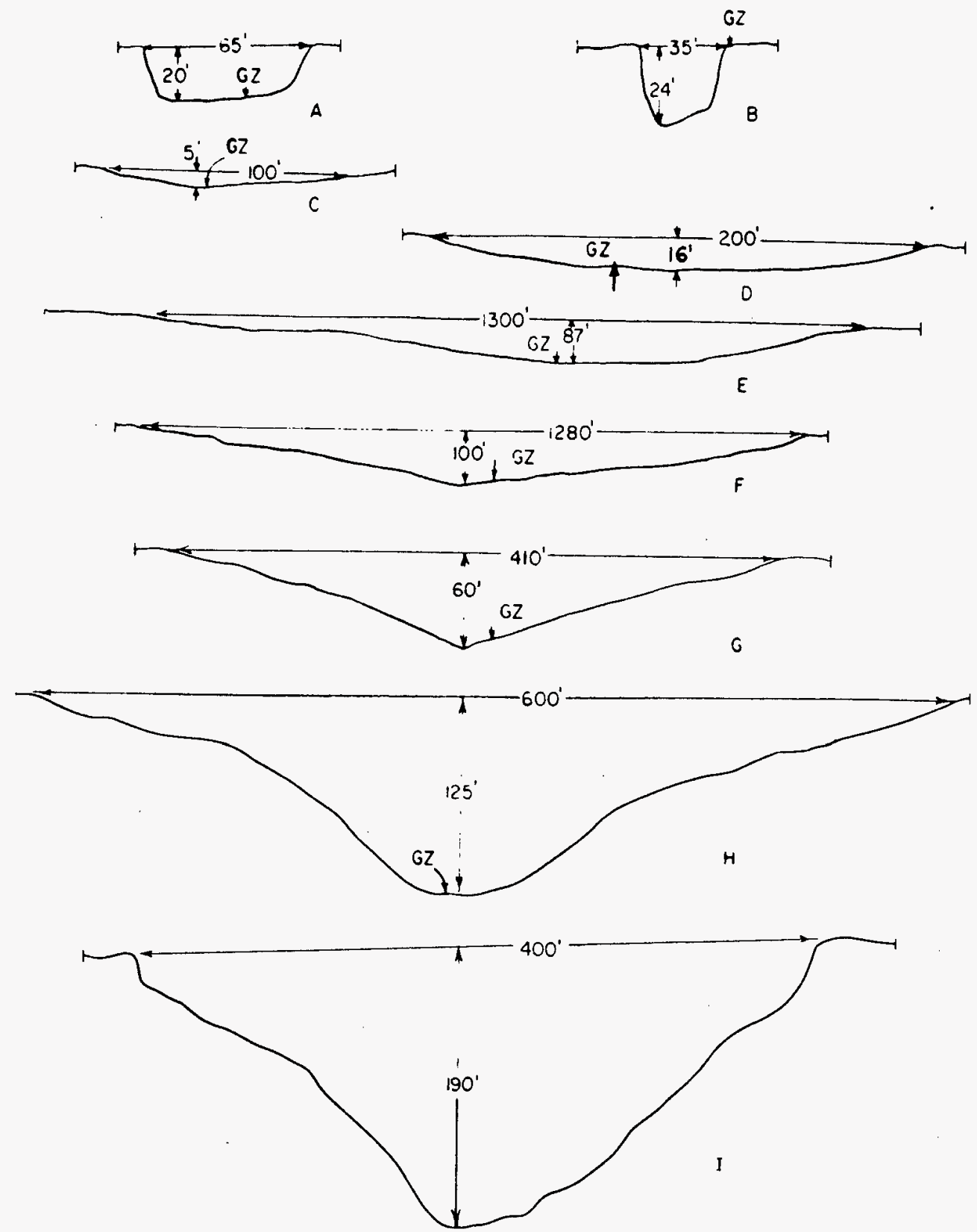

Note: Variable scale; dimensions in feet.

$\mathrm{GZ}=$ post collapse surface ground zero.

Figure 3-4. Profiles of typical Yucca Flat collapse sinks, including: "cookiecutter" (A); "posthole" (B); "dish" or "dishpan" (C-F); conical (G); stepped $(H)$; and bowl shape (I) (from Houser, 1969b). 
NTS, and an empirical study of collapse sinks by Smith (1970) reported that, because of their morphology and mode of formation, bottle-shaped sinks pose the greatest potential risk for both physical safety (from landslides and sloughing) and containment.

Collapse sinks observed at Yucca Flat range from about 3 to $244 \mathrm{~m}$ (10 to $800 \mathrm{ft}$ ) in radius (at ground level), and 0.6 to $61 \mathrm{~m} \mathrm{(2} \mathrm{to} 200 \mathrm{ft}$ ) in depth (Houser, 1970). Sinks are usually circular to elliptical in areal shape, but can be more angular in highly fractured or faulted areas. Sinks may or may not be centered on SGZ. Ellis and Snyder (1974) observed that, for Yucca Flat tests conducted in bedrock (volcanic tuff), asymmetrical collapse sinks are preferentially elongated along an east-northeast/west-southwest trending axis. This correlation is presumably a result of the regional stress field, fracture density and orientation, cavity elongation, or some combination thereof. It should be noted that this preferential elongation was not seen in tests conducted within the alluvium of the same area.

Collapse sinks in Yucca Flat are generally well defined, having relatively distinct edges or rims. Houser (1969) identified five distinct morphologic zones common to Yucca Flat collapse sinks (Figure 3-5). These zones were recognizable to varying degrees in about 90 percent of the sinks observed in Yucca Flat, and may have been present but obscured in others. Houser (1970) also reports that some sinks contain smaller, interior sinks formed from later collapse of near-surface voids within the chimney. Sink slopes typically range from relatively smooth (rounded or flat) to jagged and segmented, and sinks with high-angle slopes may be partially filled with landslide debris, obscuring part or all of the sink floor.

The physiography of Yucca Flat allows development of very well-defined sink morphologies, however this may not be the case in other areas. Shallow collapse sinks or collapse sinks in areas of high topographic relief may not be so well developed, or may be more difficult to recognize without surveying and/or knowing pre-shot conditions. To better recognize sink form, some investigators have found it useful to present detailed survey data (when available) as pre- versus post-shot elevation survey profiles, or contour maps of equal elevation change (isobase maps) (Baldwin and Townsend, 1995). The use of detailed geodetic surveys is described further in the mapping procedures portion of this report (Appendix C).

Although most often circular to elliptical in plan view, collapse sinks can also have somewhat irregular shapes. One example of an irregularly shaped collapse sink is from the CANNIKIN test. Surface collapse resulting from this test occurred approximately 38 hours after 

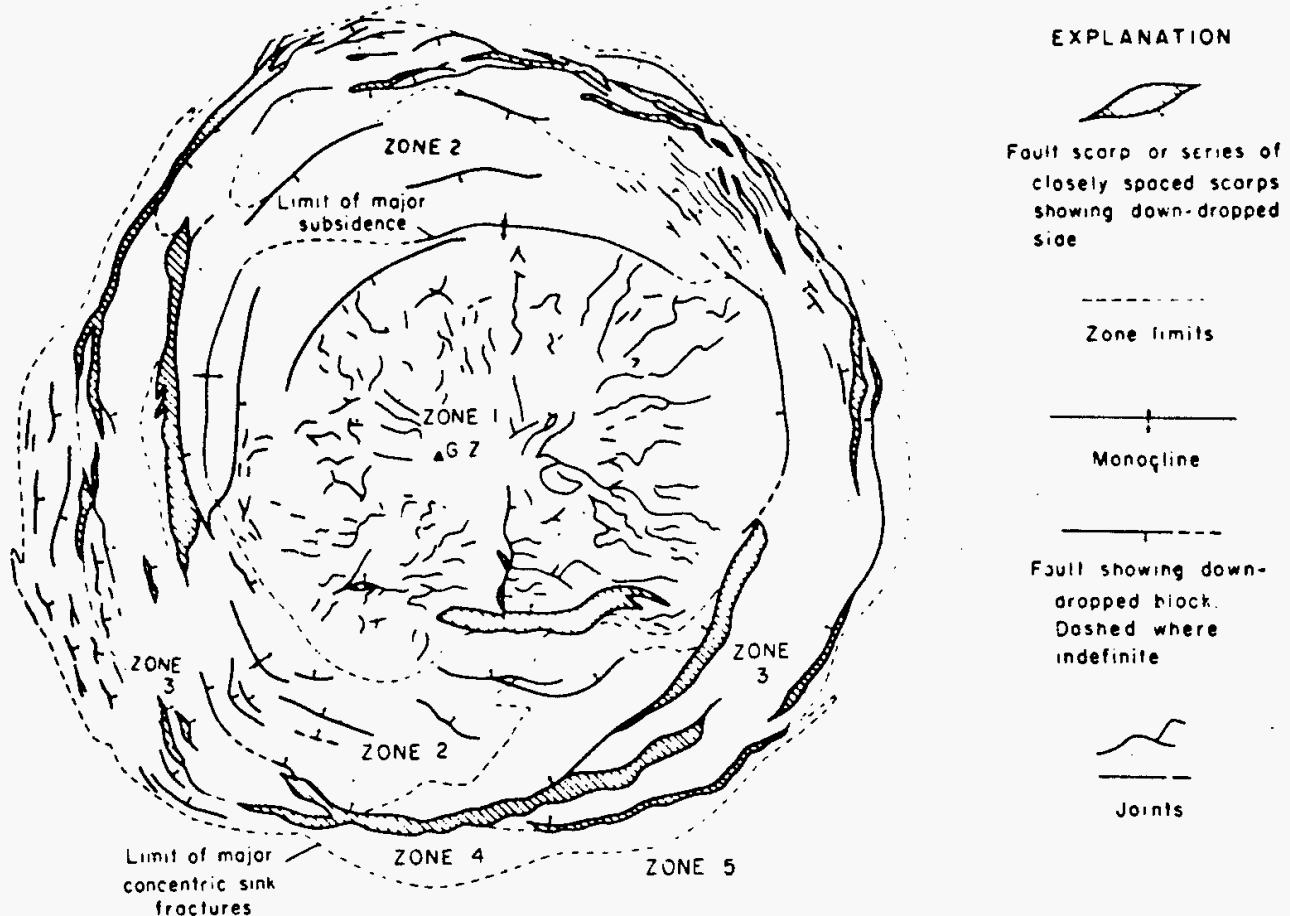

sioe

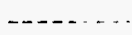

Zone limils

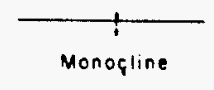

Full showing down-

oropped piock.

Dosned where

indefinite

$$
\frac{R}{\text { Joints }}
$$
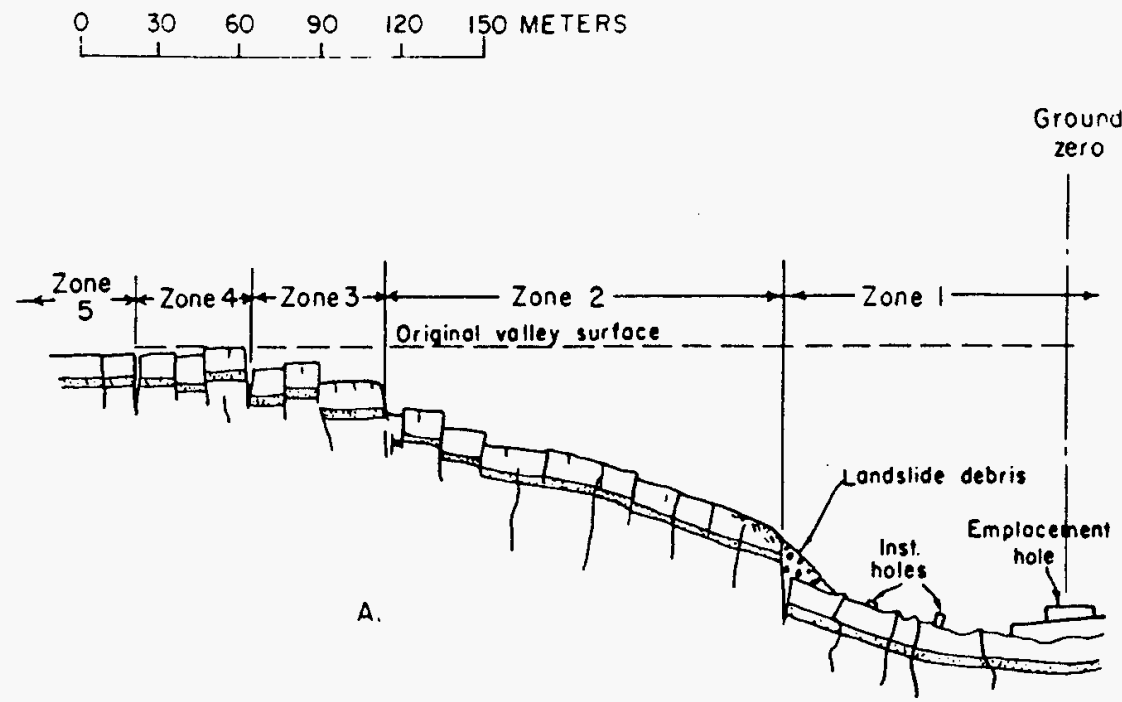

Two bosic slevelural varieties occur in zone 2

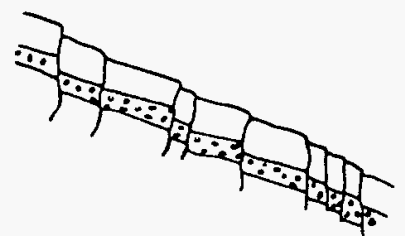

B.

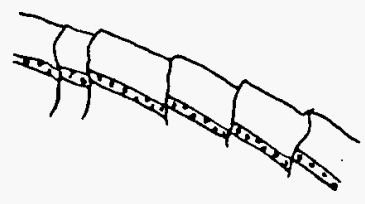

c.

Figure 3-5. Morphologic zones of a typical Yucca Flat collapse sink (adapted from Houser, 1970c). 
detonation, and post-shot isobase maps indicate an irregularly defined, roughly oval-shaped collapse feature centered about $380 \mathrm{~m}$ (1250 ft) southeast of SGZ (Morris, 1973). Although not atypical in itself, the sink is bounded by displaced fracture zones in several areas, and relatively large amounts of the displacement within the depression occurred along linear fractures. It has been suggested that the dip orientation of the underlying strata, as well as pre-existing faults and fractures may have influenced the chimneying and collapse process above this test (USGS, 1972). Maximum subsidence within the sink is less than $18 \mathrm{~m}$, however the sink has lateral dimensions (diameters) of about $915 \mathrm{~m}$ by $1270 \mathrm{~m}$ (USGS, 1972). It should also be noted that the formation of the CANNIKIN sink altered the drainage system of the area, resulting in the creation of a large lake (USGS, 1974). The hydrologic effects of CANNIKIN are discussed more completely in Section 3.1.11.1.1.

Another abnormally shaped sink occurred as a result of the FAULTLESS test, conducted in central Nevada. This test resulted in a graben-like "quasi-sink", whose boundaries roughly correspond with pre-shot fractures and lineaments (McKeown, Dickey, and Ellis, 1968). A maximum of $4.6 \mathrm{~m}$ (15 ft) of vertical offset was measured along one of these fractures, however it is unknown how much of this displacement was due to early-time (pre-collapse) compaction and/or fault displacement.

\subsubsection{Depressions and Domes}

In addition to the sometimes rather obvious topographic expressions of craters and collapse sinks, there may also be a broad area around SGZ that is depressed slightly below its pre-shot elevation. These lowered areas (herein termed depressions) are more subtle than collapse sinks or craters, and often are unrecognizable without the aid of detailed elevation surveys. In addition, depressions often are masked or obscured by larger, more distinct surface features. Depressions generally are centered on SGZ, with the amount of subsidence decreasing outward from this point. Depending mainly on the SDOB of the detonation, depressions may extend out to several hundred meters beyond SGZ. Like collapse sinks, depressions are generally concentric in shape, however they may exhibit slight eccentricities in both shape and displacement that result from differential compaction and/or local movement along faults and fracture zones. Displacements resulting from these two phenomena are addressed more fully in Section 3.1.6.2 of this report. At the NTS, depressions are best exhibited in Yucca Flat, and are less obvious near tests conducted on Pahute Mesa and Rainier Mesa. 
One explanation for the genesis and local extent of prompt subsidence around underground nuclear tests is the effect of overburden compaction. Compaction is thought to be a result of two phenomena: 1) effects of the outgoing compressional stress wave, and 2) spallation and subsequent spall closure or "slap-down." While the latter generally affects only the spall region, the former does not require spallation, and may be present beyond the spall region (App, 1985).

A calculational study by Rambo, et al, (1983) addressed surface compaction associated with the CARPETBAG test, and concluded that most of the prompt subsidence was due to near-surface compaction from both high incident stresses and slap-down stresses within the alluvium. This study complemented earlier work by Allen (1981), who proposed a compaction damage model for alluvium that, under the given assumptions, was in good agreement with the surface subsidence data used. Allen (1981) also suggested that because of its relatively weak intergranular bonding, alluvium was more susceptible to permanent compaction than other NTS test and overburden media. This conclusion is supported by the general observation that subsidence is better developed in the alluvium of Yucca Flat, than the more competent lavas and tuffs of Pahute Mesa and Rainier Mesa. It should be noted that neither study calculated the effect of deep movement/compaction, and Rambo, et al., (1983) suggested that weak subsurface layers closer to the working point may play some role in compaction and subsequent surface displacement.

Another type of surface displacement induced by a UNE is the permanent, upward warping or bulging of the ground surface above a test, herein referred to as "doming." This phenomenon was noted after the GNOME test, which was conducted in a thick formation of bedded salt near Carlsbad, New Mexico in 1961 (see Table 2-2). The overburden above the test location

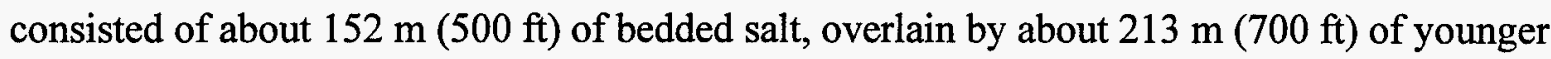
sedimentary rocks (Cooper and Glanzman, 1971). At the surface, an area about $122 \mathrm{~m}(400 \mathrm{ft}$ ) radially outward from SGZ was permanently domed upward a maximum of $0.6 \mathrm{~m}(1.9 \mathrm{ft}$ ) (Gard, 1963). Vertical and horizontal displacement of beds outward from the detonation was indicated from both post-shot mining and drilling activities, and it is suspected that plastic deformation within the salt deposit was at least partially responsible for the displacement (Gard, 1963). It should also be noted that the cavity produced by this test did not completely collapse, and the resultant chimney extended only a short distance into the overlying strata.

Descriptions of the GNOME dome were cursory at best, and there is little documentation of the doming phenomena associated with other underground nuclear tests. This may be due in part to 
other surface effects features such as collapse sinks and depressions which may obscure or diminish displacement. In addition, the physical characteristics of the overburden also may play a role in controlling the extent and magnitude of doming.

\subsubsection{Rubble Mounds}

The formation of a rubble mound or "retarc" (crater spelled backwards) above an underground nuclear test is an isolated and unique phenomenon. The only rubble mound in U.S. testing experience occurred at the NTS as a result of the SULKY detonation in 1964. SULKY was a cratering test designed to define the geometry of a crater and lip from an overburied (deeper than optimum for cratering) nuclear detonation (Videon, 1965). SULKY had an announced yield of $0.092 \mathrm{kt}$, and was buried at a depth of $27 \mathrm{~m}(90 \mathrm{ft})$ in basalt. The test produced a circular rubble mound at SGZ, that was about $6 \mathrm{~m}$ high near the center and $24 \mathrm{~m}$ wide (diameter) at its base. A small circular crater was observed near the top of the mound, measuring about $9 \mathrm{~m}$ in diameter and $3.5 \mathrm{~m}$ in depth. The mound consisted of large blocks of basalt rubble that were confined mainly to the area of the mound itself (i.e., ejecta was limited to a few blocks scattered nearby). In short, the test parameters and geologic setting resulted in the formation of a column of rubble to the surface without appreciable ejecta or throw-out.

Although a typical crater was not formed as a result of the SULKY test; this experiment contributed greatly to the understanding of scaling laws for cratering. Because of the potential applications to quarrying and mining, the results of this experiment were of much interest to those working in the Plowshare Program. However, mound formation occurs in test regimes that border on catastrophic surface rupture and throw-out (crater formation), and subsequent release of radioactivity. As with craters, logistical and radiological concerns restricted the application of this type of test, and later containment requirements dictated that underground nuclear tests be conducted at much higher SDOBs than would allow formation of surface mounds.

Consequently, U.S. experience with rubble mounds is very limited.

\subsubsection{Surface Cracks}

Surface cracks are defined here as breaks or partings of the ground surface, formed by explosioninduced mechanical failure. For underground nuclear tests, the stresses required to initiate 
cracking are induced either directly, through stress-wave effects such as spallation and spall closure, or indirectly, through secondary mechanisms such as fault movement or collapse sink formation. Cracks are most prevalent and best developed within the spall region. However, it is not uncommon for cracking to occur outside the spall zone, especially along fault zones.

Cracks may be somewhat randomly oriented, but usually trend along certain preferred directions or patterns relative to the SGZ that can be categorized as (1) linear, (2) concentric or circumferential, or (3) radial. All three of these crack orientations were observed after the CARPETBAG test, as shown in Figure 3-6. UNE-induced crack patterns also have been classified on the basis of their symmetry around the SGZ (McKeown, Dickey, and Ellis, 1967). In this classification scheme, cracks are described as (1) radiosymmetrical, (2) bisymmetrical, and (3) linear. Radiosymmetrical cracks include both radial and concentric cracks, and cracks described as bisymmetrical include those oriented similarly to pre-existing fracture patterns. In both classifications, the term linear indicates relatively straight fractures that typically occur along the surface traces of fault zones.

Individual cracks generally range in width (aperture) from a "hairline" (Figures 3-7) to several tens of centimeters, and in length from several centimeters to several hundreds of meters.

Groups of cracks, however, can consist of numerous preferentially aligned parallel or en echelon linear cracks, that can extend out to several thousands of meters in length. As might be expected, large cracks (wide and long) usually are associated with relatively high-yield detonations and/or nearby fault zones. Cracks along topographic free surfaces such as the edge of a mesa or ridge also can be fairly prominent, however, much of the apparent severity can be attributed to the effects of spall (Figure 3-8).

UNE-induced cracks commonly form preferentially along pre-existing zones of weakness such as faults, joints, or lineaments (Barosh, 1965, 1968). Cracks also form preferentially on or along man-made or "prepared" surfaces such as roads, trailer parks, drill pads, etc. (Figure 3-9 and 3-10), and as stated earlier, along topographic features that may enhance spall (free surfaces such as drainage ways, mesa rims, etc.). In addition, pre-existing cracks or crack scars from previous tests can be reactivated by subsequent nearby tests. At the NTS, these reactivated cracks are usually somewhat weathered or eroded in appearance (Figure 3-11) and often contain finegrained fill that may be preferentially revegetated (Figure 3-12). 


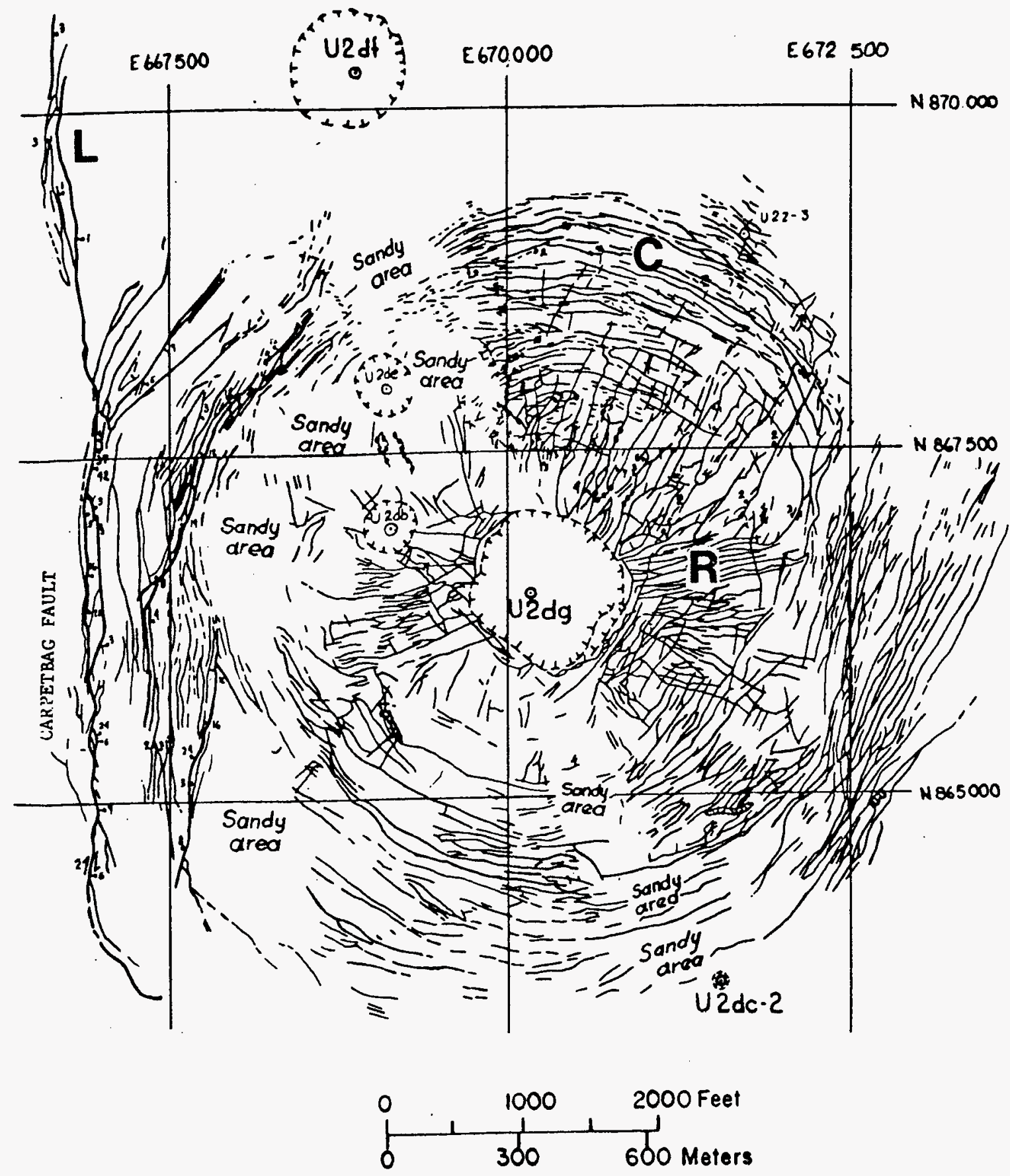

Explanation: Bar and ball on downthrown side of faults; displacements in inches. Pressure ridges are shown by dots superimposed on fracture lines. Hatchured subcircular lines outline sinks.

$C=$ concentric cracks; $R=$ radial cracks; $L=$ linear cracks.

Figure 3-6. Crack map of the CARPETBAG test (U2dg) (adapted from Jenkins, 1973). 


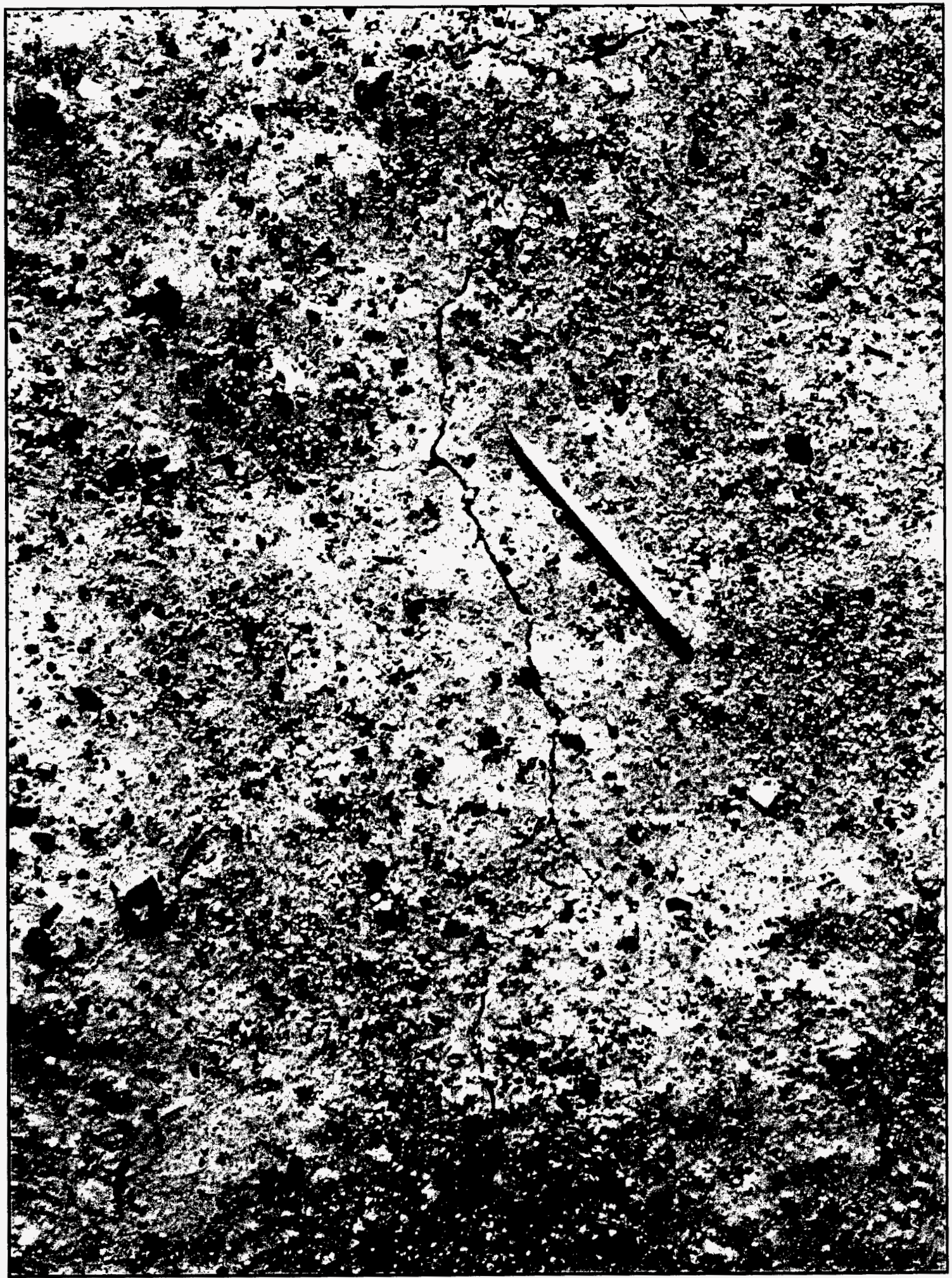

Figure 3-7. Hairline crack in alluvium resulting from the DALHART test (U4u). 
This page intentionally left blank. 


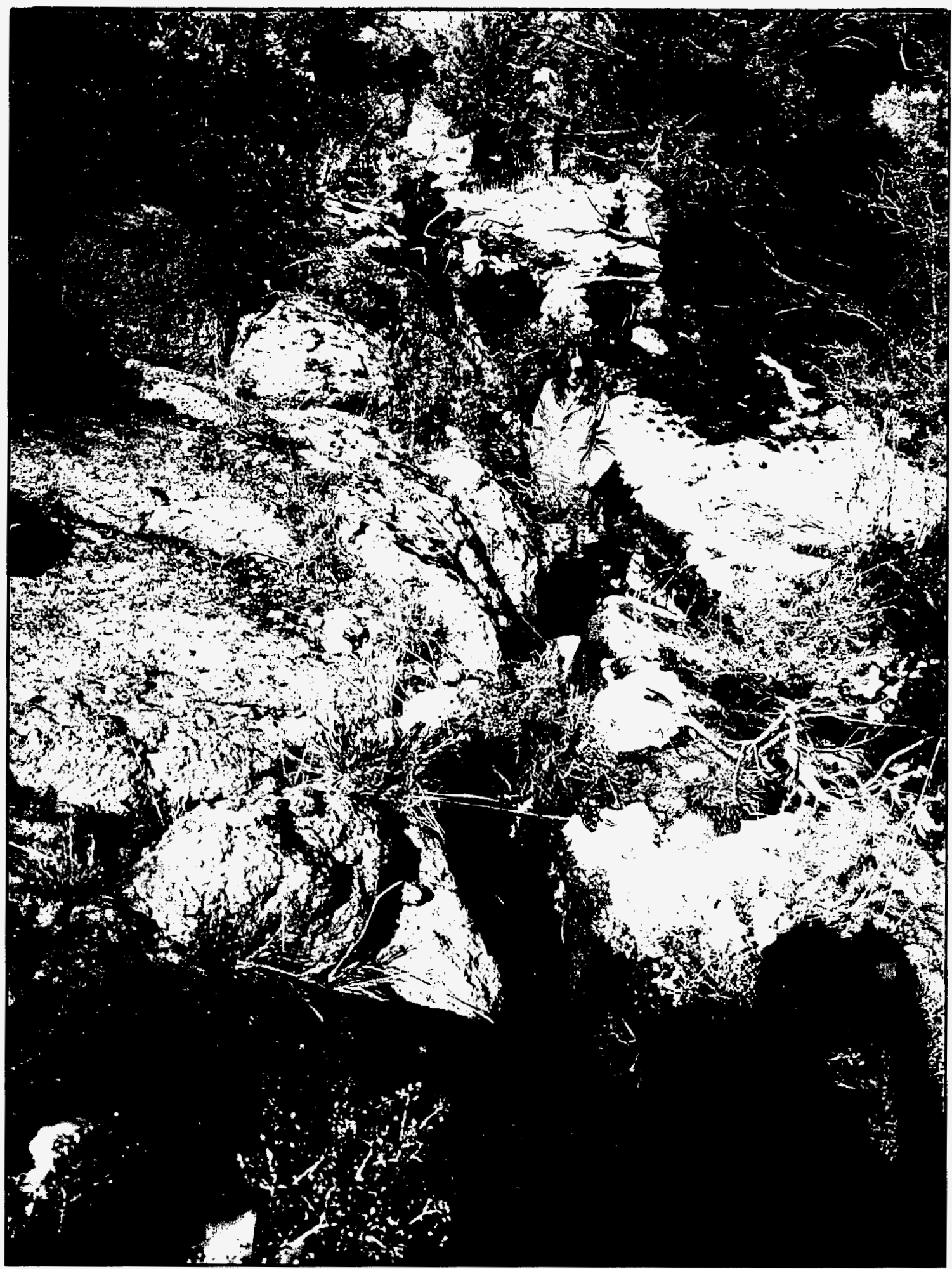

Figure 3-8. Large, spall-enhanced crack along fault trace near the edge of Rainier Mesa. Crack is approximately $450 \mathrm{~m}$ southeast of SGZ. 
This page intentionally left blank. 


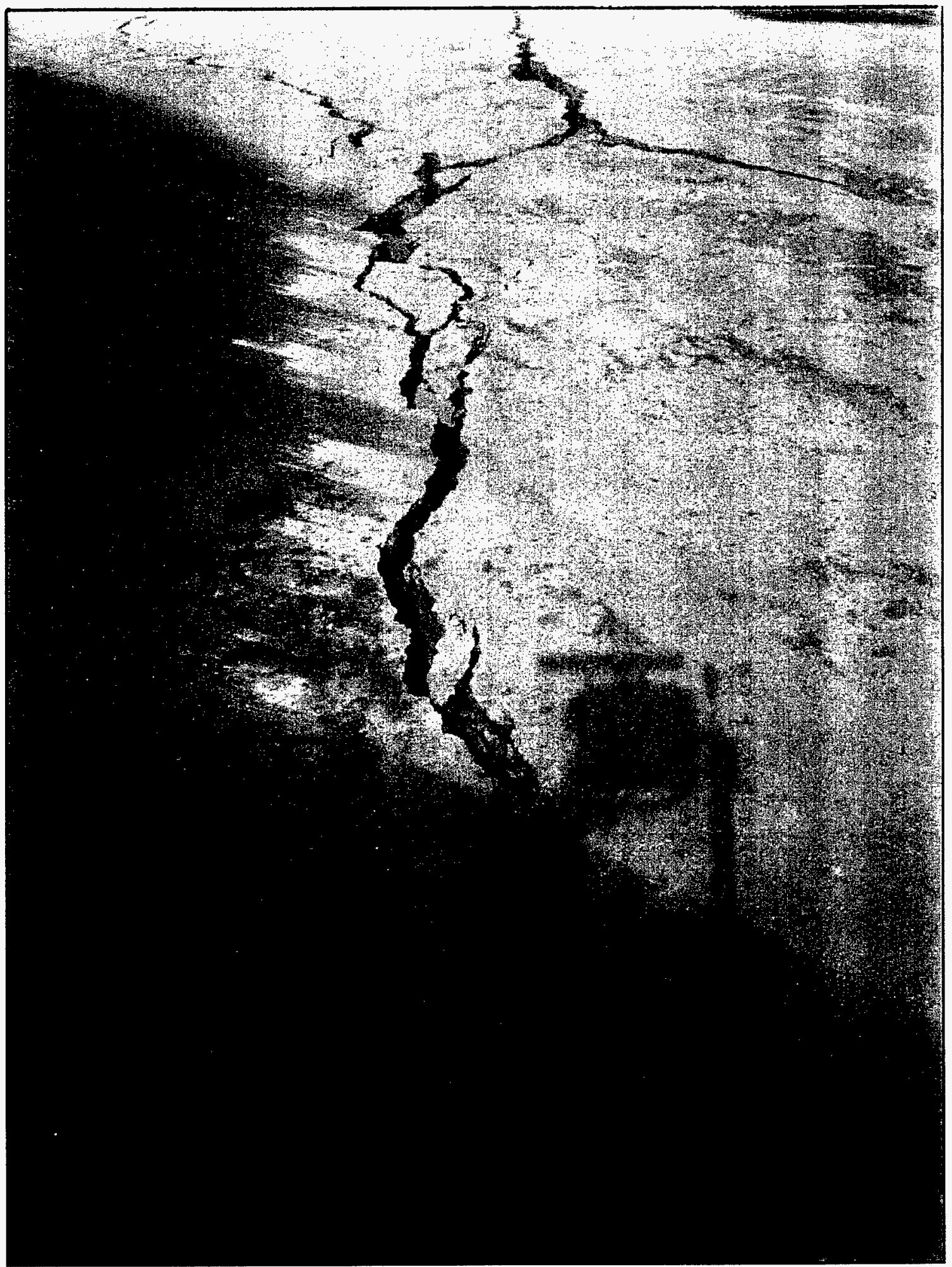

Figure 3-9. Cracks in prepared surface (trailer park) on Rainier Mesa. These cracks formed prior to collapse sink formation. 
This page intentionally left blank. 


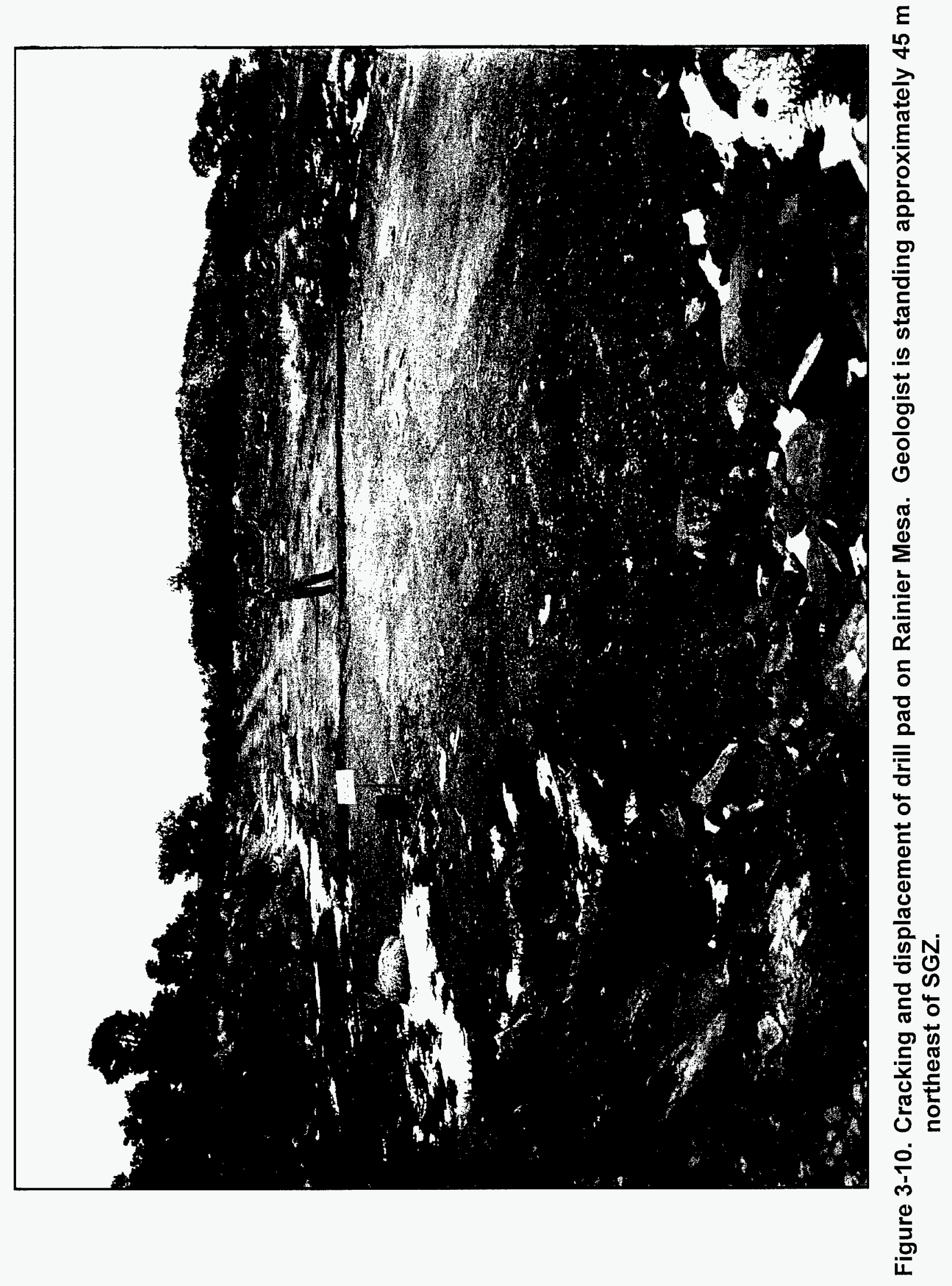


This page intentionally left blank. 


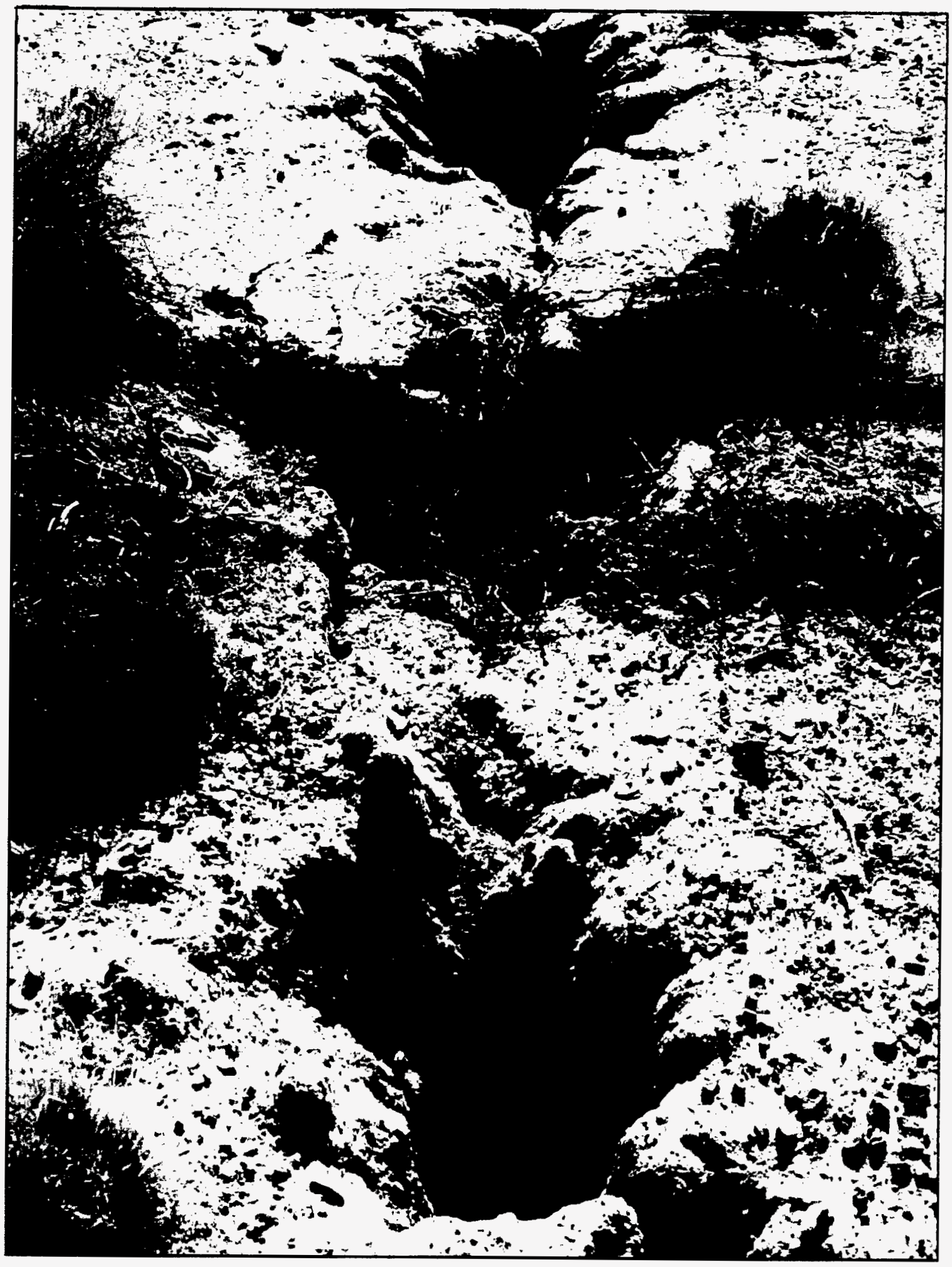

Figure 3-11. Crack scar southwest of drillhole U3mq, Yucca Flat. 
This page intentionally left blank. 


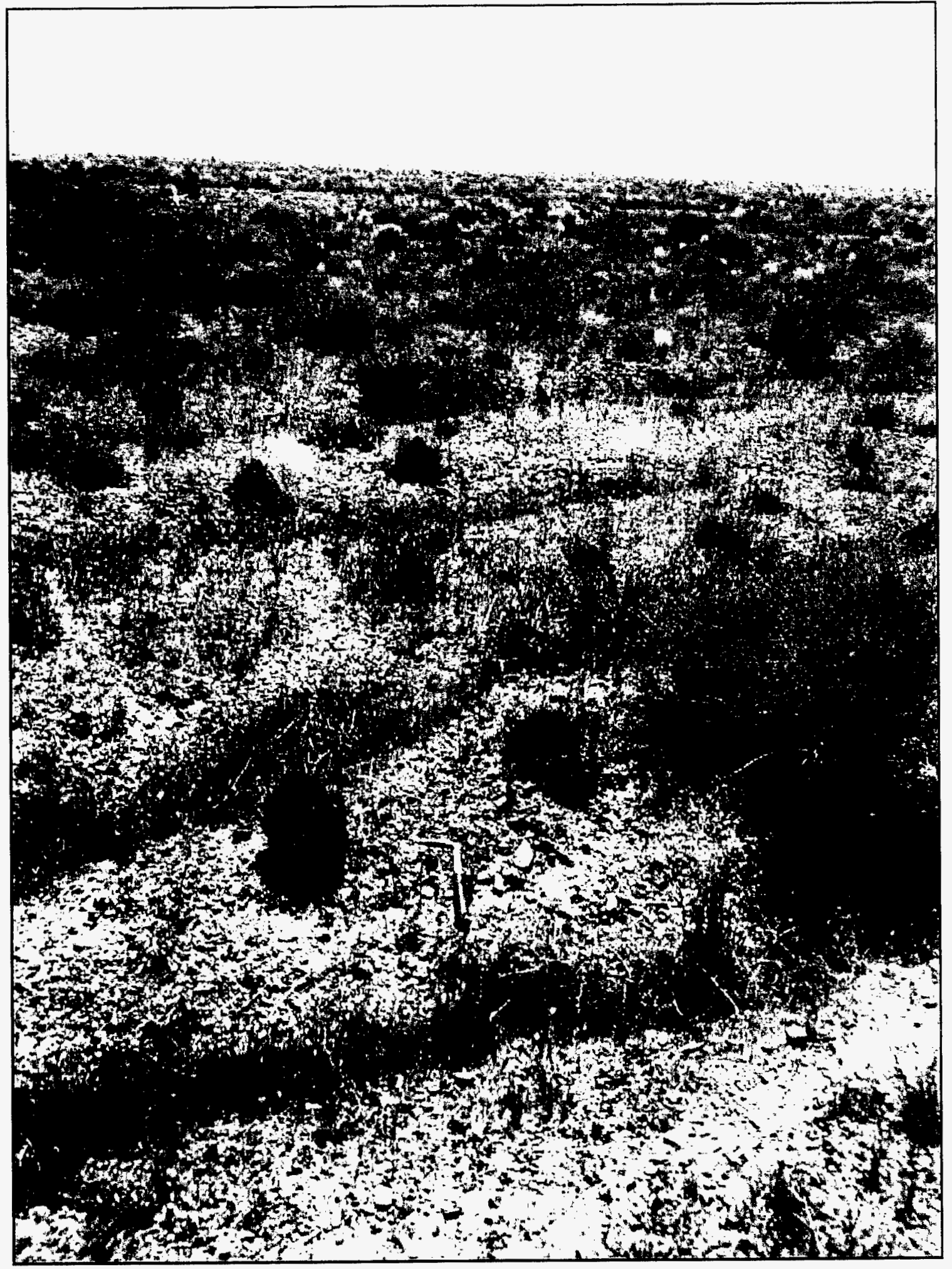

Figure 3-12. Revegitated cracks from the CARPETBAG test (U2dg). 
This page intentionally left blank. 
The characteristics of the uppermost surface material in the area around a test also play a major role in the development of cracks. Properties such as lithology, texture, and induration often determine the nature and extent of cracking. For example, cracks may not be as prevalent or as well developed in an unconsolidated fine-grained sand as they are in a well-cemented gravel or desert pavement (see Figure 3-6). Cracks have also been observed to follow pre-test textural features such as mud cracks (Figure 3-13). Although most NTS test experience involves crack development in near-surface deposits of alluvium (especially in Yucca Flat), there also have been documented instances of crack development in bedrock outcrops of tuff (Pahute and Rainier Mesa experience), basalt (Buckboard Mesa), granite (Climax at the NTS, SHOAL in central Nevada), and in soil horizons (turf and peat at Amchitka, caliche at the NTS, etc.).

Preferential alignment of cracks is often thought to be a manifestation of the presence, movement, and/or differential compaction along some subsurface structure, such as a buried scarp or fault. Because these features pose a containment concern, the presence of a preferred orientation or alignment of cracks is of great interest to the containment community. The presence of aligned cracks also may influence field operations (such as placement of drilling reserve pits) and/or the siting and construction of facilities. Surface cracks that are controlled or influenced by surface features such as prepared surfaces or drainage features typically are considered benign and, consequently, are of less interest.

For the purposes of this report, cracks are grouped into three categories: (1) fractures, (2) faults, and (3) block chatter. It is often impractical or impossible to make a distinction between these features, hence the generic term "crack." However, each of these features has some unique characteristics that are described below.

\subsubsection{Fractures}

Fractures are defined here as surface cracks that have a limited vertical extent. Whereas it is usually easy to determine the lateral extent of a fracture at the ground surface through mapping, determination of the three-dimensional extent of a fracture is not such a simple task.

Observations from trenches and boreholes in the alluvium of Yucca Flat indicate that while most of the fractures observed extend less than $30 \mathrm{~m}$ into the subsurface, many extend an indeterminable amount farther (McKinnis and Kao, 1993; Carr, 1965). It has also been noted that some cracks observed in the subsurface do not extend completely up to the ground level (McKinnis and Kao, 1993). It is thought that both the vertical and lateral extent of surface cracks 
This page intentionally left blank. 
'7ely eoon人 'syoedo

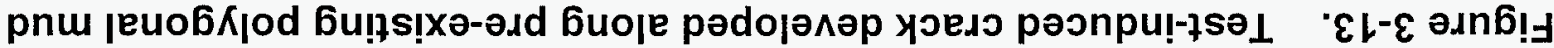

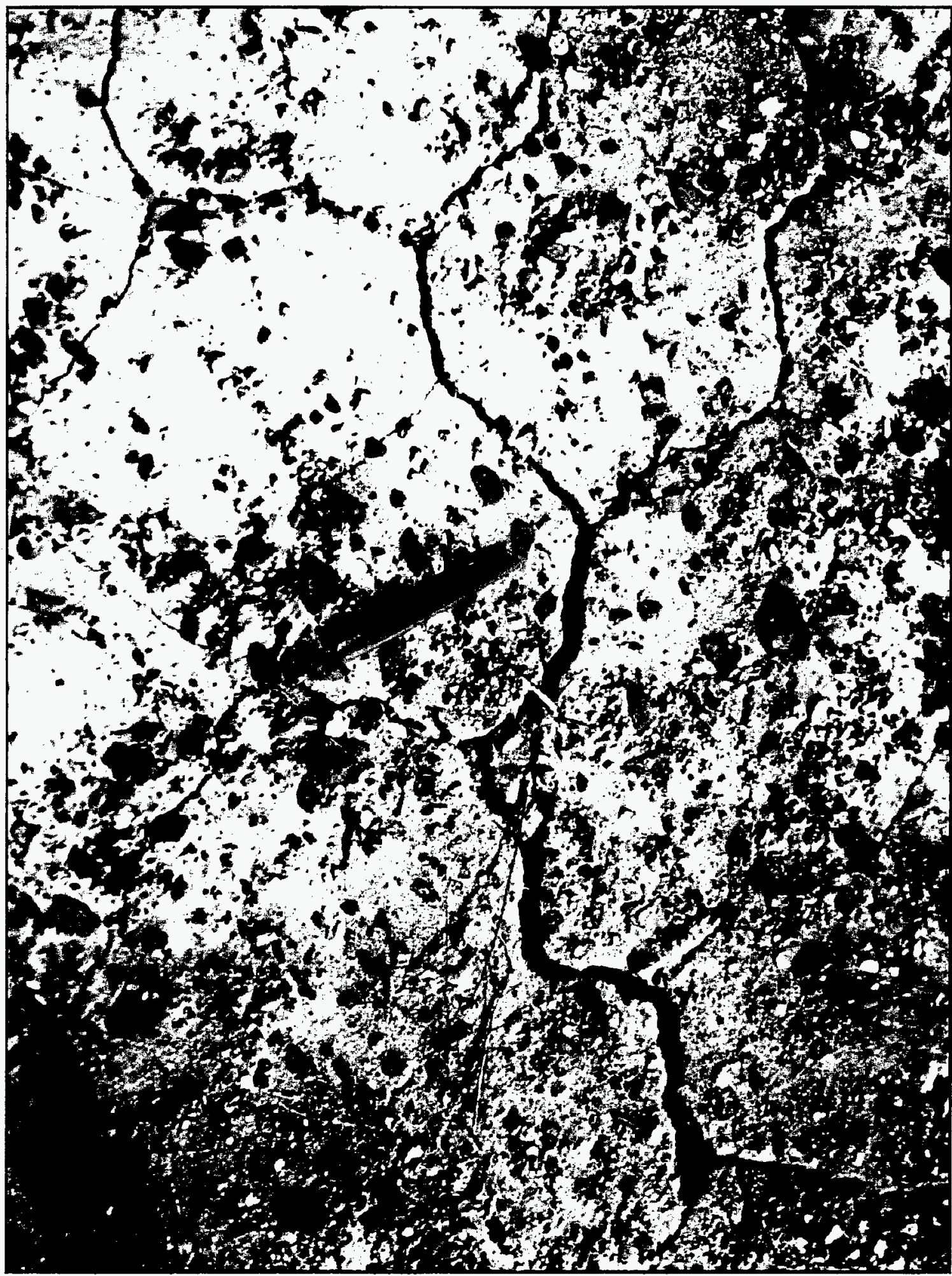


This page intentionally left blank. 
corresponds with the spall region; however, this correlation should be used as a reasonable guideline, and not as a hard and fast rule.

Other observations noted by McKinnis and Kao (1993) indicate that explosion-induced fractures in the Yucca Flat alluvium are usually widest at the surface and generally narrow with depth, although the reverse has been observed as well. Fractures in relatively soft material, such as the alluvium of Yucca Flat, tend to fill with fine-grained sediment relatively quickly. In Yucca Flat, fractures also have been known to receive copious amounts of water, which tends to widen the cracks near the surface, and also helps fill the fractures with sediment. The hydrogeologic effects of fractures are discussed more completely in Section 3.1.11.1.4.

\subsubsection{Faults}

A fault is defined as a vertically extensive fracture along which there has been displacement parallel to the fracture plane. Faults typically are referred to in the singular, however they often consist of a zone of several parallel or en echelon faults. As discussed above, it is often difficult to determine the vertical extent of a fracture, so geologists must look at other evidence in interpreting whether a crack is indicative of a fault. These indicators include, but are not limited to displacement, areal extent, trend, and density of surface cracks, and the pertinent surface and subsurface data available for the area. It also has been observed that cracking is often less extensive on the fault block opposite a test (i.e., there are fewer and shorter cracks on the fault block adjacent to the fault block in which the test was conducted).

In Yucca Flat, faults that have exhibited explosion-induced displacement include the Carpetbag Fault (Figure 3-14), the Yucca Fault, and the Area 3 Fault. Of the latter two, the Yucca Fault seems the more sensitive to nearby detonations, in terms of both scaled range versus movement, and magnitude and extent of observed displacement. Dickey (1968) reported that displacement along the Yucca Fault has been observed most often within scaled distances of $1000 \mathrm{~W}^{1 / 3} \mathrm{ft}$, and the Area 3 Fault within distances of $500 \mathrm{~W}^{1 / 3} \mathrm{ft}$. Vertical displacements due to individual nearby tests along the Yucca Fault are generally less than $30 \mathrm{~cm}$. However, movement has not been systematic, and it appears that successive detonations of similar yield and range from the fault resulted in decreasing amounts (both areal extent and magnitude) of observed displacement (Dickey, 1968).

UNE-induced fault movement has been observed in locations other than Yucca Flat. Tests conducted on Pahute Mesa have indicated the presence of many formerly hidden faults, which 
This page intentionally left blank. 


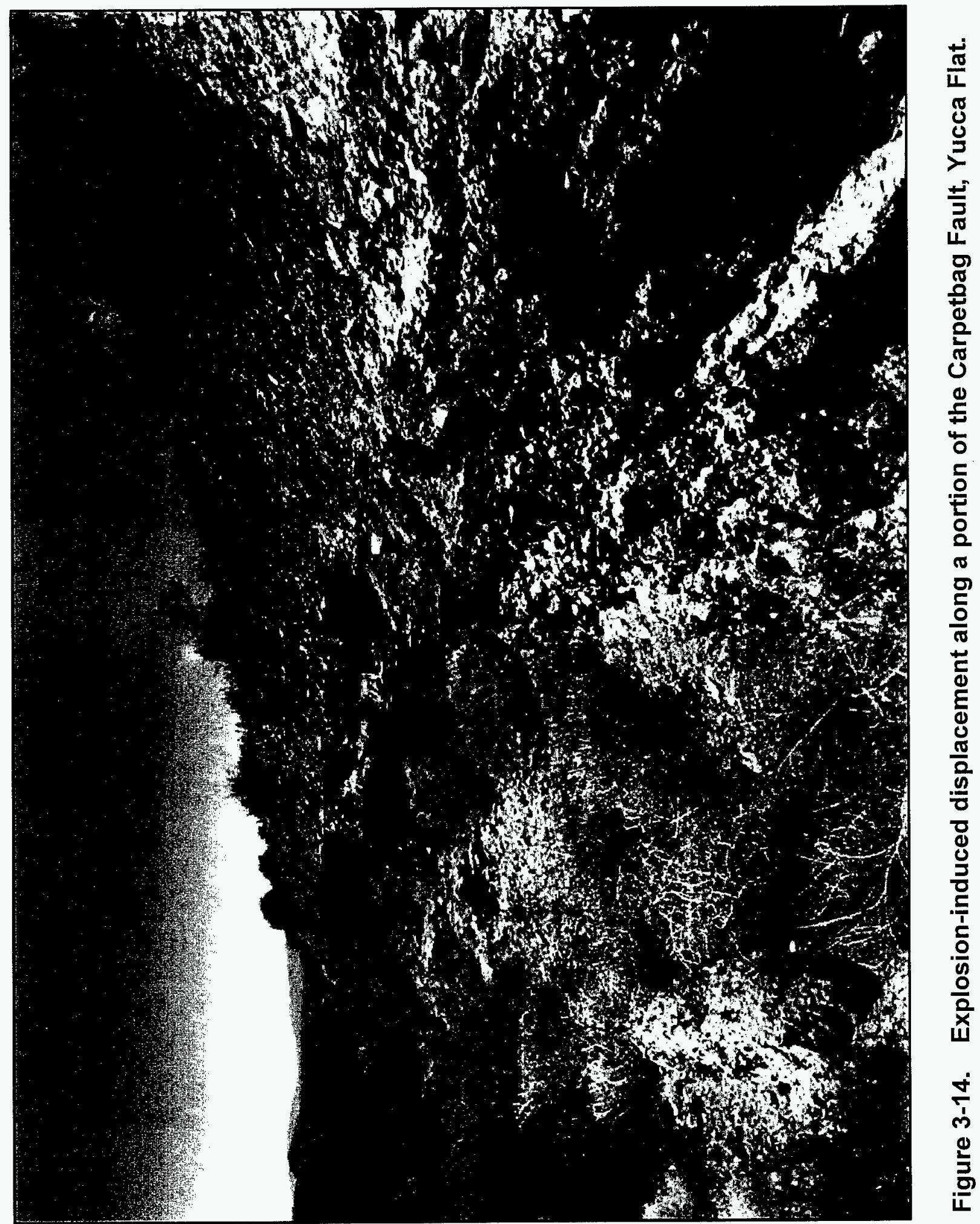


This page intentionally left blank. 
subsequently have been named for the tests that revealed them or made them more prominent (e.g., the Handley Fault, the Almendro Fault, the East and West Greeley Faults, etc.). The BOXCAR test, one of the highest-yield U.S. underground nuclear detonations, resulted in a vertical displacement of about $0.9 \mathrm{~m}(3 \mathrm{ft})$ and horizontal displacement of about nine $\mathrm{cm}(0.3 \mathrm{ft})$ along the subsequently named Boxcar Fault (Dickey, McKeown, and Ellis, 1968). Fractures along this pre-existing fault zone were mapped for more than 7,925 $\mathrm{m}(26,000 \mathrm{ft})$, extending as far as $6,096 \mathrm{~m}(20,000 \mathrm{ft})$ away from SGZ.

Tests conducted outside the boundaries of the NTS have produced similar results. The FAULTLESS test conducted in central Nevada resulted in as much as $4.6 \mathrm{~m}(15 \mathrm{ft})$ of vertical and $0.9 \mathrm{~m}$ ( $3 \mathrm{ft}$ ) of horizontal displacement along a previously recognized nearby fault (McKeown, Dickey, and Ellis, 1968). Aerial photography, however, revealed that this fault exhibited only partial displacement immediately after detonation, with most displacement occurring possibly hours afterward. In addition, this fault partially defined a post-shot graben or "quasi-sink" that developed near SGZ (as mentioned in Section 3.1.3). This evidence supports the conclusion that most of the displacement along this fault was possibly a result of chimneying and subsequent collapse sink formation.

Although displacement is most often associated with faults, it is not uncommon for some fractures to display evidence of offset. Because of the local extent of fractures, this offset is limited to the uppermost veneer of surface material which does not return to its original position after passage of the stress waves. However, as stated earlier, the vertical extent of cracks is often difficult to determine based on surface observations. In addition, displacement due to differential compaction also may cause offset along fractures or faults.

One attempt to differentiate the various components of displacement caused by an underground nuclear test was reported by App (1985). In this study, detailed pre- and post-shot elevation surveys were conducted along lines oriented roughly perpendicular to known faults within the spall radius of several detonations. Although he considered the results somewhat preliminary, App concluded that, for the tests studied: (1) displacement along faults was indicated within a narrow zone at the surface, even in surficial deposits of alluvium, (2) relative motion was normally in the same direction as the original fault offset (however the reverse has been observed elsewhere), and (3) some faults exhibited more explosion-induced displacement than was evident from observed surface cracks. In addition, he concluded that evidence of differential compaction 
of the alluvium above buried fault scarps is not always observed, and that the phenomenon may or may not occur, depending on the site.

\subsubsection{Block Chatter}

Block chatter is perhaps more a process than a feature. This phenomenon occurs as a result of the stress-induced interaction between blocks of near-surface rock. These blocks are delineated by the pre-existing joint system of the rock, which can include local, through-going, and/or cooling joints (if the rock is extrusive in origin). Explosion-induced stresses cause these blocks to "bounce around," converging, diverging, and grinding past one another. This movement often results in the expulsion of fine-grained sediment or fill within the fractures, and in a well developed joint system can result in a prominent display of a mosaic pattern of cracks. These effects can be particularly dramatic in areas covered with a thin blanket of snow. The term block chatter (or designated symbol thereof) is often used to denote the presence of these types of features or an overall appearance of these features, rather than an interpretation of the process itself.

\subsubsection{Rock Spall}

Rock spall is the chipping, fracturing, or fragmentation with an upward and/or outward heaving, of slabs of rock caused by a compressional stress wave at a free surface. This definition is different from the definition given earlier for "spall," mainly in terms of scale: rock spall occurs along individual rocks or outcrops, whereas spall refers to a phenomenon affecting rock from the surface into the subsurface (tens to hundreds of meters). Like cracks, rock spall occurs preferentially along pre-existing zones of weakness. Rock spall is most dramatic where outcrops of bedrock are well exposed, or where ground motion is focused, such as mesa rims or along crests of ridges. This phenomenon also has been observed underwater off the coast of Amchitka, Alaska, after the CANNIKIN test (USGS, 1972). Explosion-induced rock spall was common in the volcanic rock of Rainier Mesa and Pahute Mesa. Figure 3-15 shows an example of rock spall along an outcrop of volcanic rock on Rainier Mesa. 


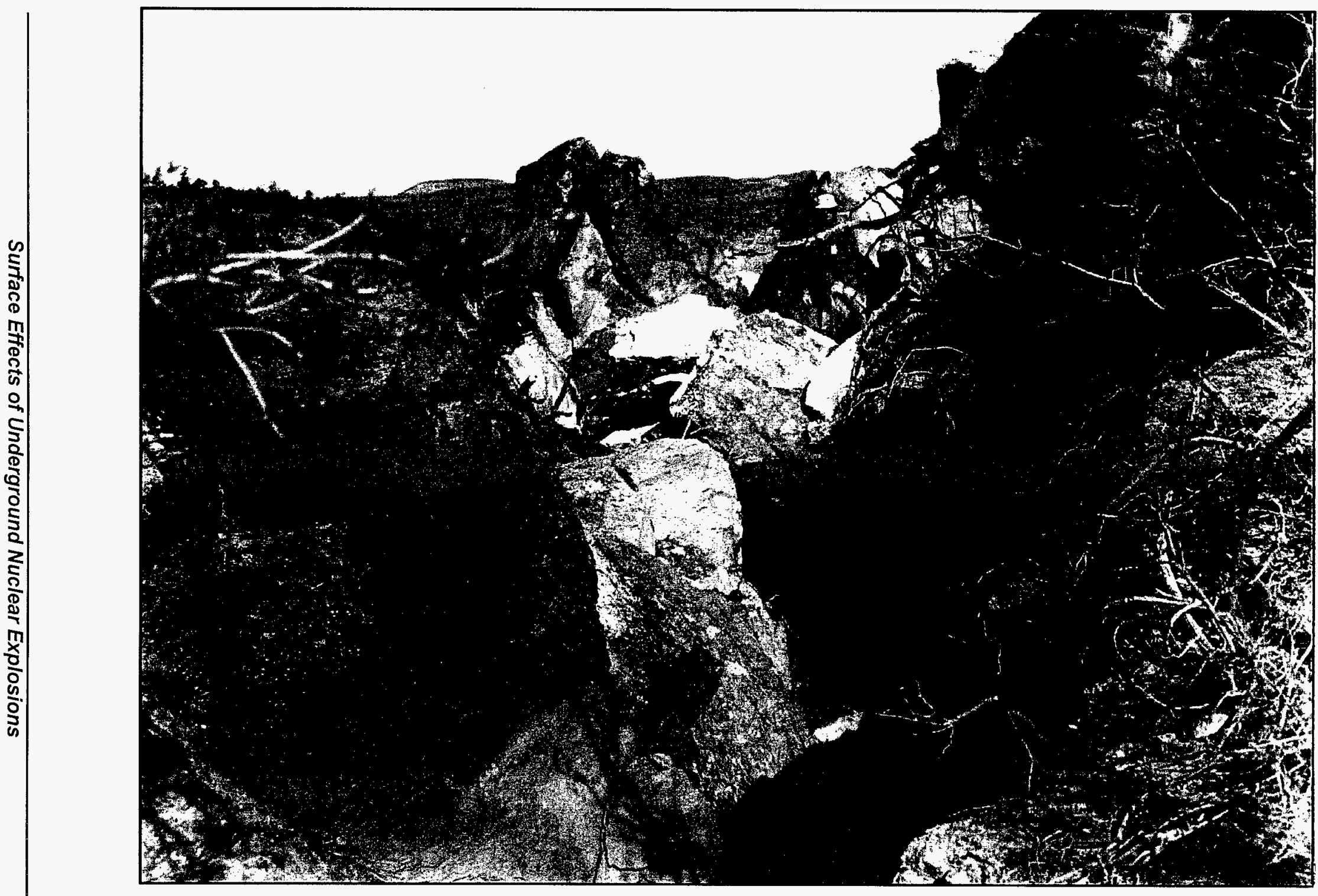

Figure 3-15. Rock spall along the edge of Rainier Mesa. Geologist is standing approximately $122 \mathrm{~m}$ 心) northeast of SGZ. 
This page intentionally left blank. 


\subsubsection{Mass Movement}

Mass movement is the term used collectively for the downslope migration of geologic materials. Although mass movement is a natural process, it can be triggered or exacerbated by human activity, such as underground nuclear testing. Other, more common human activities that can aggravate movement include the oversteepening of slopes (cutting roadways, terraces, quarries, etc., into sloped areas) and the clearing away of stabilizing vegetation (e.g., clearcut logging). Other factors that contribute to the severity or frequency of movement include the water content of materials involved and the orientation of land surfaces with respect to the point of detonation. Mass movement may be classified on the basis of the type of material moved and the nature of the movement. The following are some examples of mass movement that have been observed following underground nuclear tests.

\subsubsection{Rock Fall}

In steep-sloped areas, spalled or loose cobbles or boulders can, under the force of gravity and impetus of ground motion, roll or tumble away from their original locations. The size of affected material can vary, but as might be expected, the phenomenon is most noticeable and destructive with larger boulders and steeper slopes. Highly jointed or weathered rock are usually the best candidates for rock fall. In addition, differential erosion of alternating layers of hard and soft rock can result in undercutting of layers, which can also intensify the process. Repeated rock falls in the same location can result in accumulations of rubble and debris, also known as talus deposits.

Because of its steep-sided slopes and caprock of jointed, welded tuff, Rainier Mesa has a great deal of potential for rock falls. A typical example of the aftermath of a rock fall on Rainier Mesa is shown in Figure 3-16. Rock falls also were noted after many of the larger detonations conducted on Pahute Mesa. Rock falls triggered by the GREELEY test were observed out to distances of almost $13 \mathrm{~km}$ (8 miles) from SGZ, and possibly were present much farther (Dickey, et al., 1967). Extensive rock falls also occurred as a result of nuclear tests on Amchitka Island in Alaska (McKeown, et al., 1967; USGS, 1970, 1972). All three underground tests conducted at this site resulted in rock falls, mostly along the steeply sloped coastal areas (especially those that experienced uplift and/or were facing away from SGZ). Rock sizes ranged from a few centimeters to a little over three meters, and it was noted that almost all rocks had been dislodged along pre-existing joint planes. 
This page intentionally left blank. 


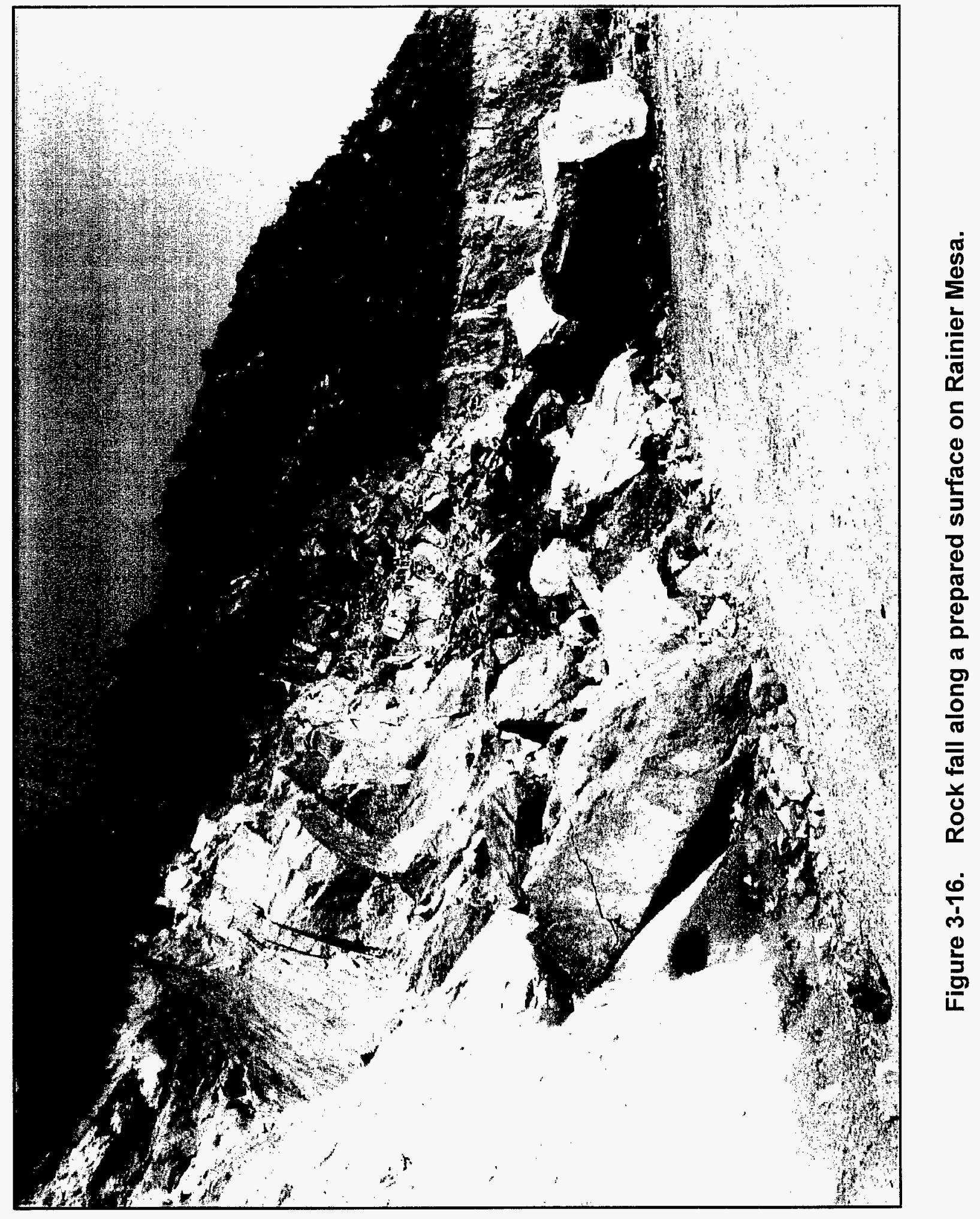


This page intentionally left blank. 


\subsubsection{Landslides}

In areas of high relief where unstable accumulations of debris or talus have accumulated, UNEinduced ground motion can trigger or reactivate an abrupt, large-scale mass movement, otherwise known as a landslide. Depending on the scale and rate of movement, landslides can be quite destructive, especially in areas where rock has been extensively fractured or eroded, or where large accumulations of talus exist. Test-induced ground motion also can cause reactivation of pre-existing natural and UNE-induced landslide deposits, or cause certain areas to be more susceptible to future landslide activity. A secondary effect of both rock falls and landslides can be the formation of clouds of airborne dust (see Section 3.1.10).

Minor but extensive rock falls and landslides were noted after the RULISON test in Grand Valley, Colorado. A post-test report by the Environmental Research Corporation (ERC) (1970a) noted at least 13 relatively small rock and soil movements within $6.6 \mathrm{~km}$ of SGZ of this detonation. The authors of this report speculated that the severity of rock movement near this test was intensified by the undercutting of weathered, unconsolidated sandstones and shales due to differential erosion. Minor landslides also were triggered by the RIO BLANCO test near Rifle, Colorado (Whicker, Alldredge, and Hanson, 1973), and were not uncommon after larger detonations on Pahute Mesa (Tueller and Bruner, 1973). In addition, pre-existing landslide deposits were reactivated following the CANNIKIN test on Amchitka Island in 1971 (USGS, 1972).

\subsubsection{Slumping and Sloughing}

Rock falls and landslides represent two generally violent and chaotic styles of mass movement. Conversely, slumping and sloughing typify a more fluid and coherent manner of UNE-induced movement. Slumping usually occurs within unconsolidated deposits of relatively fine-grained material such as soils or sand, that can move or flow downslope as a coherent unit or mass. Slumping can occur in either wet or dry conditions, but typically is exacerbated by wet conditions. Sloughing involves blocky, collapse-type movement along zones of locally steep relief such as stream or pond banks. Areas with steep relief such as stream cuts or canyons can be susceptible to both slumping and sloughing, especially if stream banks or canyon walls face away from the detonation. As mentioned above, the type and density of ground cover in an area can play an extremely important role in these types of movement, often having a mitigating effect on extent and magnitude of movement. 
Slump deposits and slump cracks induced by underground nuclear testing were observed in the wet surface deposits of Amchitka Island. At this site, slumping of glacial outwash gravel, turf and peat, and beach sand occurred along the sides of trenches, pond and stream banks, and coastal highlands (McKeown, et al., 1967; USGS, 1970, 1972; Everett and Amundsen, 1975). Figure 3-17 shows slump deposits and scars along the coastal highlands of Amchitka Island, resulting from the CANNIKIN test.

Evidence of slumping and sloughing was prominent along Fawn Creek, near the RIO BLANCO test in Colorado. It was estimated that test-induced sloughing occurred along as much as half of the lineal bank-line of the creek within about one mile of the test location (Whicker, Alldredge, and Hanson, 1973). Post-test observations also indicated that most of the sloughing occurred along the steeper (greater than $45^{\circ}$ ), non-vegetated banks of the creek. Secondary effects of this sloughing on nearby streams included minor redirection, temporary damming and impoundment, and increased stream load (see Section 3.1.11.1).

\subsubsection{Pressure Ridges}

A pressure ridge is a relatively narrow surface undulation or "buckle" resulting from horizontal pressure and shortening of the near surface by an underground nuclear test. Pressure ridges generally range in height from a few centimeters to about two meters, but usually are less than 30 $\mathrm{cm}$ high. Pressure ridges are generally less than two meters wide, and can be several tens of meters long. In plan view, pressure ridges are typically straight to slightly curved, but can be locally sinuous. Cracks are not uncommon along the crests of pressure ridges, and some larger ridges exhibit evidence of slight overthrusting. A small pressure ridge typical of Yucca Flat is shown in Figure 3-18. Although pressure ridges were observed in all three of the main test areas (Yucca Flat, Rainier Mesa, and Pahute Mesa), they probably are exhibited best on Pahute Mesa. Pressure ridges also were noted after the FAULTLESS test in central Nevada, and on the tundra of Amchitka Island after the CANNIKIN test (USGS, 1972).

\subsubsection{Disturbed Ground}

In addition to the more dramatic effects described earlier in this report, ground motion induced by an underground nuclear test can have less distinct or profound effects as well. These more 


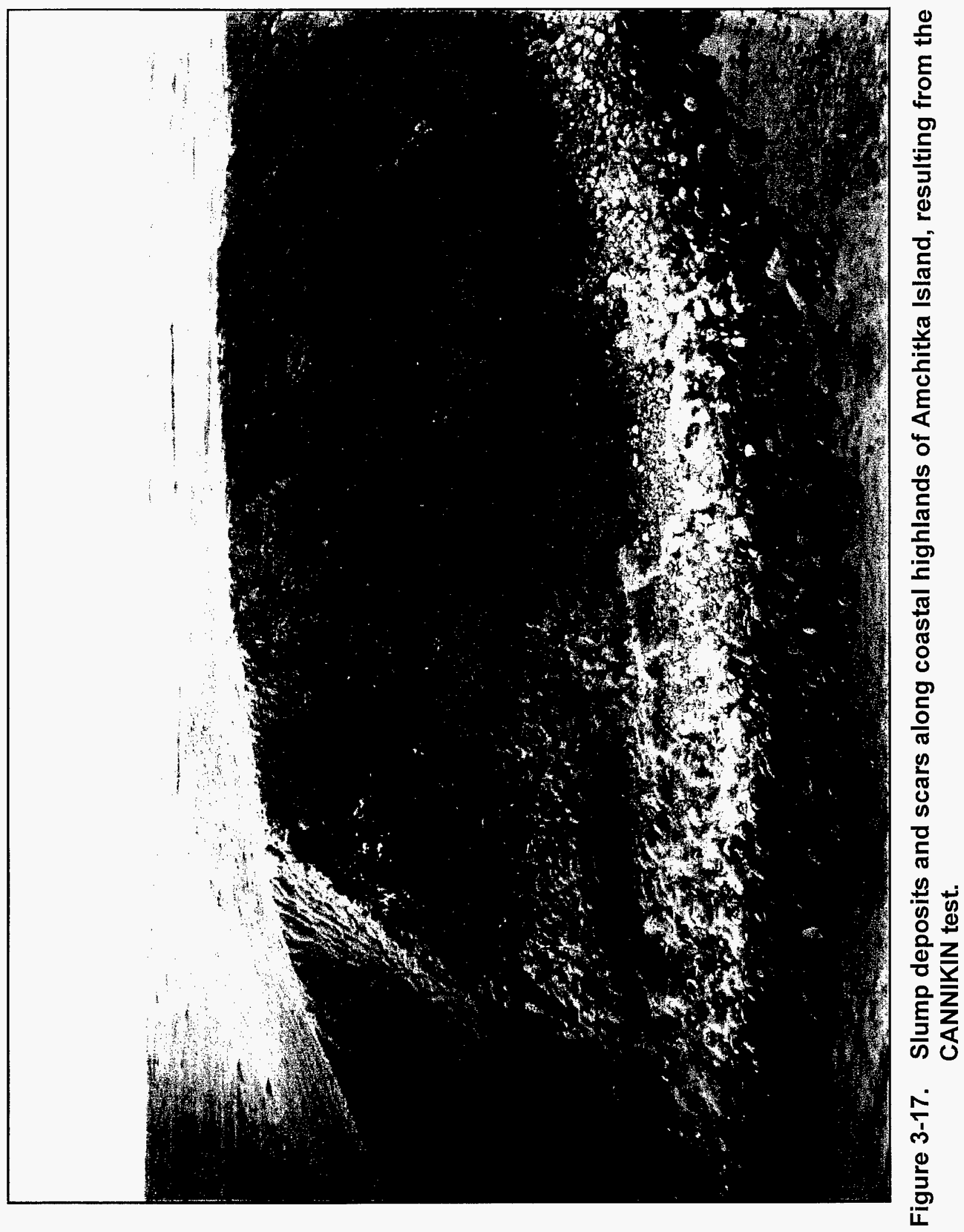


This page intentionally left blank. 


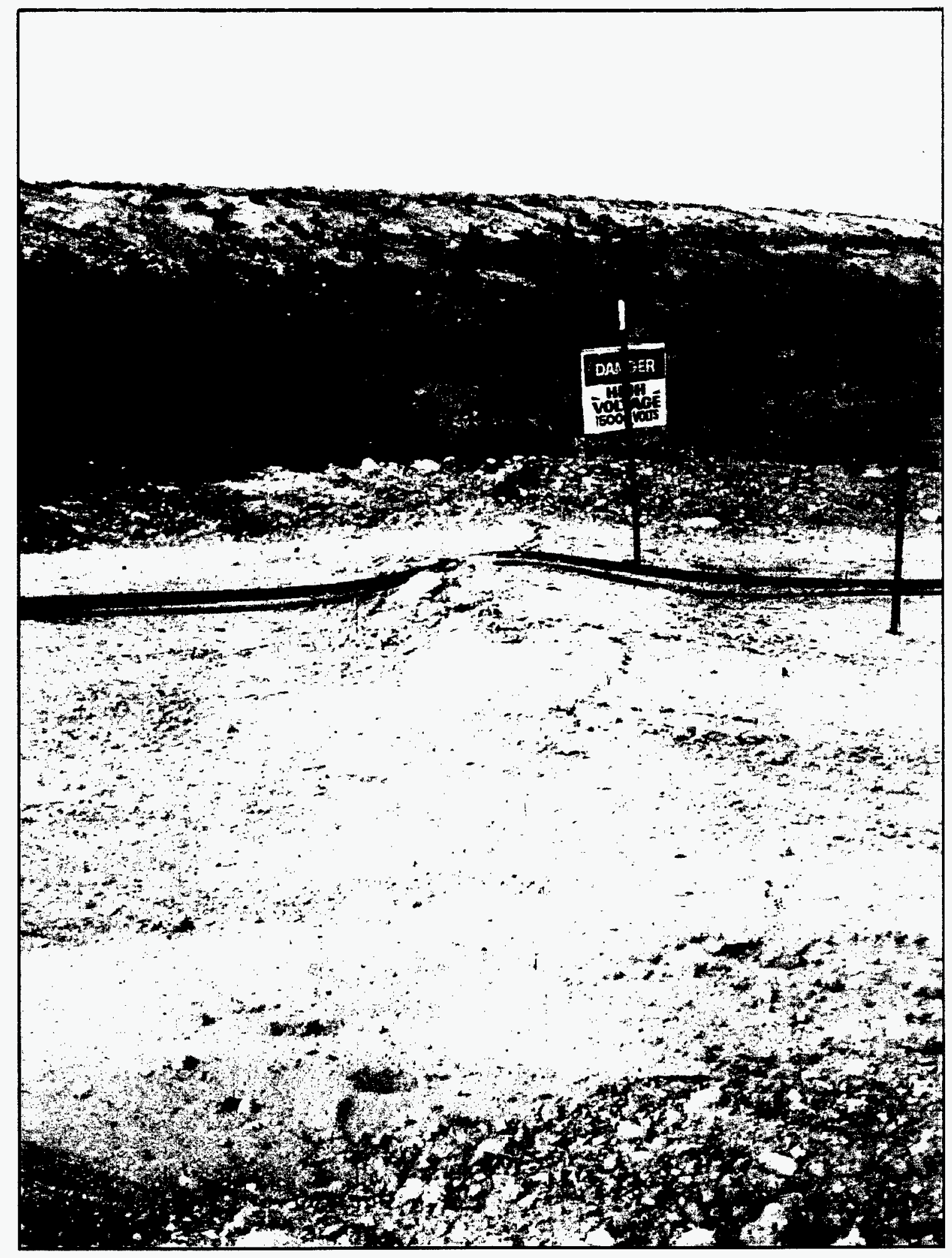

Figure 3-18. Pressure ridge in alluvium of Yucca Flat, resulting from the DALHART test (U4u). 
This page intentionally left blank. 
subtle effects are generally limited to the very near surface, and are cumulatively known as disturbed ground. Disturbed ground encompasses many different types of features, most of which are a result of rapid accelerations of the earth's surface. Disturbed ground can include features such as fluffed dirt, collapsed animal burrows, overturned rocks, turf disruptions (fluffed or torn mats), and the propagation and subsequent accumulation of airborne dust.

Features such as fluffed dirt or turf and collapsed animal burrows can be very subtle, and their identification may require previous knowledge of the area. Other features such as overturned rocks can be slightly more noticeable, especially if the rocks are large, partially fractured, or show evidence of past orientation or position (such as moss or algae growth, desert varnish; caliche, vegetation "shadows", etc.). Turf disruptions observed after the Amchitka Island tests ranged from subtle rolls and ridges, to large blocks of turf and peat dislodged along fracture zones. An example of the latter was observed about $610 \mathrm{~m}$ east of the CANNIKIN SGZ, near the intersection of two fracture zones (Figure 3-19). The CANNIKIN test caused similar turf disruptions along many other fractures or faults in the vicinity, as well as slippage/slump and tearing of turf mats along sloping areas such as pond and stream banks (USGS, 1972).

As seen from the air (real-time observations and aerial photography), one of the most noticeable effects after an underground test is the formation of clouds of airborne dust. Limiting discussion to contained underground tests (i.e., tests that do not breach the surface and result in ejecta or throw-out ), dust particles are lofted into the air either directly or indirectly via three main testrelated ground disturbances: (1) upward acceleration of dust from the initial shock-wave (just after detonation), (2) sink collapse; and (3) mass movement (especially landslides and rock falls). The amount of dust that can become airborne after a test is primarily a function of the severity of ground motion and surface conditions near the test. Surface attributes and conditions that can affect dust cloud formation include soil type; soil condition (loose, hard-packed, moisture content, etc.); ground cover (vegetation type and density); and the extent and magnitude of any manmade disturbances (construction, dirtwork, etc.). Depending on wind conditions, dust clouds can dissipate rapidly or settle slowly over the area.

One of the most spectacular known examples of dust cloud formation occurred after a French underground test at the Hoggar Test Site, near In Ecker, Algeria. A report of geologic effects by Faur'e (1970) noted three distinct dust clouds immediately following detonation of one test. The source of these clouds was cited as areas of severe collapse and landslide activity. Dust 
This page intentionally left blank. 


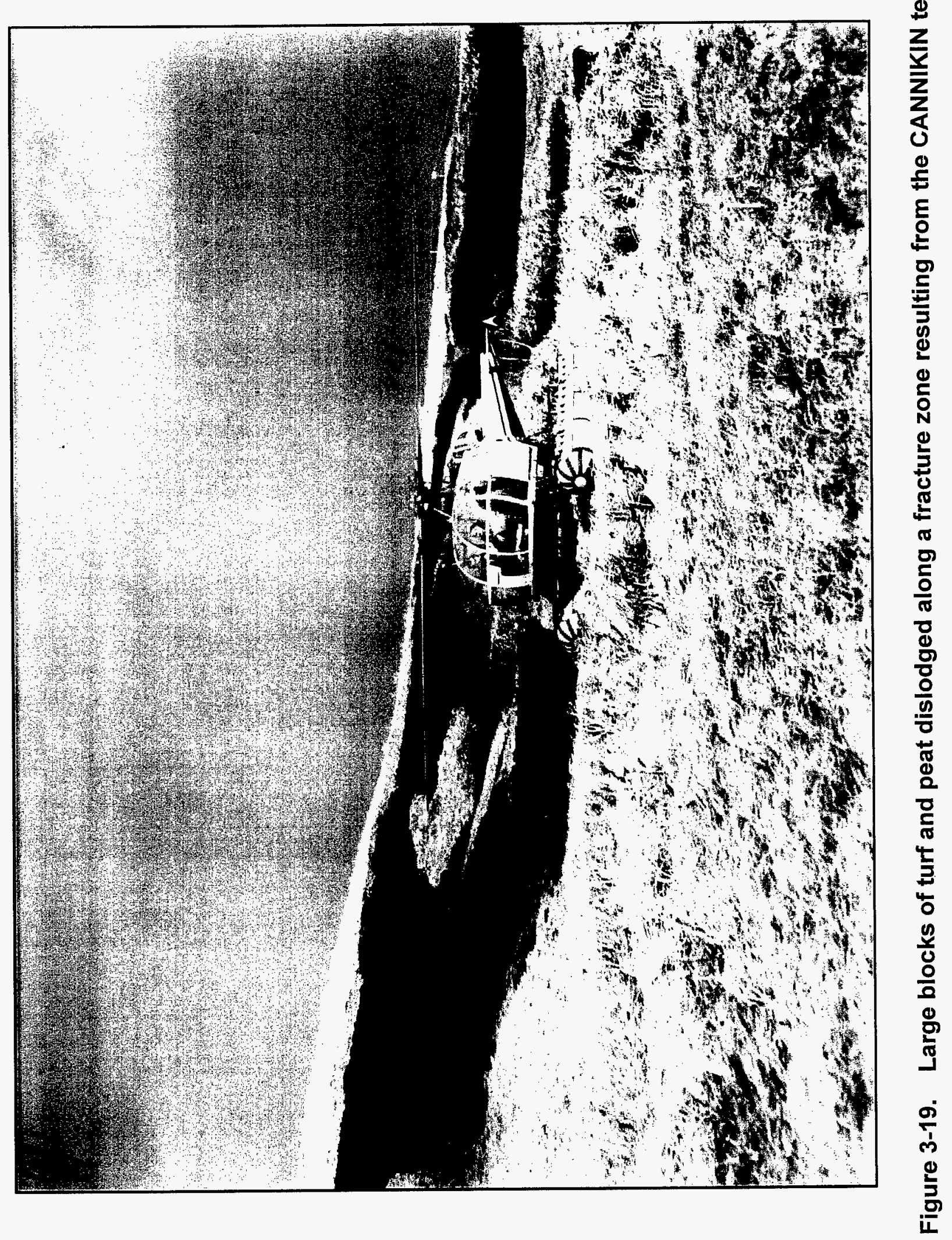


This page intentionally left blank. 
accumulations of more than five centimeters were observed, completely covering soil and masking roads in some places. This dust deposit initially had rather sharp boundaries, covering an area of approximately $11.8 \times 10^{6} \mathrm{~m}^{2}$ around SGZ of the test (Faur'e, 1970).

\subsubsection{Hydrologic Effects}

Many of the surface effects described in previous sections of this report can directly influence the morphology and subsequent hydrology of the land surface above an underground nuclear test. As described earlier, surface effects range from relatively subtle features to rather large topographic landforms. The mechanisms that produce these features also can modify the geohydrologic properties (porosity, permeability, pore pressure, etc.) of surface and subsurface layers in the immediate vicinity of a test, and under certain conditions can form other unique and strictly hydrologic features or effects as well. UNEs also can affect the quality or character of the water itself, both in the subsurface and on the surface.

The following sections describe some of the non-radiological types of hydrologic effects observed at the different test locations. Again, most U.S. experience with these types of effects comes from the NTS, where the arid climate is not conducive to the formation of many UNEinduced surface hydrologic features. However, there is some U.S. experience in wetter climates, in particular, the tests conducted in Alaska on Amchitka Island.

\subsubsection{Geomorphologic Influences}

Test-induced changes in the local topography generally result in the most noticeable hydrologic effects. In fact, the object of many peaceful nuclear explosions (especially in the former Soviet Union) was to test or apply "nuclear excavation" concepts to water resource development. Changes in the shape of the land surface have a direct impact on the type of surface water (stream, pond, etc.) observed near a test, as well as the direction and rate at which the water is moving. Typical examples of hydrogeologic processes that occur with a change in profile and/or gradient include stream capture or piracy, incised channels, redirected channels, abandoned channels, ponding, and superimposed drainage systems. Coastal areas also can display evidence of abrupt changes in profile and/or gradient through shoreline processes, however test-related experience of this type is very limited. 
3.1.11.1.1 Collapse Sinks and Depressions. Collapse sinks can have perhaps the greatest influence on the topography and subsequent hydrogeology of an area. Alone or in combination with surface depressions (described in Section 3.1.4), these features can act as drainage basins for surface runoff, creating lakes or ponds in the process. Because of their circular to subcircular areal shape, collapse sinks may also eventually result in a somewhat radial drainage pattern locally around the sink.

Based on U.S. experience, the most dramatic example of a collapse sink affecting the hydrology of an area was on Amchitka Island after the CANNIKIN test. The collapse feature created by this test captured the runoff of both the north and south forks of White Alice Creek, resulting in the formation of "Cannikin Lake." This lake is centered on the roughly triangle-shaped collapse sink caused by CANNIKIN, about $457 \mathrm{~m}$ (1500 ft) east of the SGZ. Cannikin Lake has a maximum depth of about $9.5 \mathrm{~m}$ (31 ft), and covers an area of approximately 12.1 hectares (30 acres) (Gonzalez, Wollitz, and Brethauer, 1974).

Subsidence induced by tests on Amchitka also resulted in the modification of existing lakes or ponds. The tilting of lakebeds within the depressions caused by these tests was the most prevalent effect. The collapse feature caused by MILROW resulted in the tilting of two lakes toward SGZ. This depression also caused one of the lakes to drain into the sink region, rather than to the west (away from the sink) as it did prior to the test (USGS, 1970).

Although significant, the impact of collapse sinks on natural drainage systems at the NTS is not conspicuous because of the lack of surface water. As stated in Appendix B, precipitation events at the NTS are usually isolated, sporadic, and of short duration, and typically do not result in enough moisture for surface runoff. In Yucca Flat, any runoff that does occur is transported toward the southcentral portion of the valley through numerous shallow channels and washes, typically traveling only a short distance before it is absorbed into the alluvium. However, in portions of Yucca Flat where the density of underground tests is high, the natural drainage has been all but obliterated by collapse sinks. Although typically dry, these sinks serve as catchment basins (at least for their immediate vicinity), further restricting lateral flow of surface water within the valley.

3.1.11.1.2 Craters. Like collapse sinks, UNE-induced craters are another type of topographic depression that can have a major influence on the surface hydrology of an area. As previously mentioned, the use of craters in water-resource development was of much interest to both the 
United States and the former Soviet Union. Cratering tests and applications toward this end were mainly for the conveyance and storage of water (canals, harbors, reservoirs, etc.) within the craters themselves. In at least one instance, the former Soviet Union also utilized the elevated rim of ejecta along the outer perimeter of a crater as a "crater-lip dam" (Nordyke, 1975). This crater-lip dam was positioned so as to block the flow of a river, thereby creating a reservoir upstream.

3.1.11.1.3 Mass Movement. Explosion-induced mass movement also may result in the blocking and impoundment of surface water. Massive turf slides triggered by the CANNIKIN test resulted in temporary damming and impoundment of White Alice Creek (Everett and Amundsen, 1975). In this instance, upstream flooding was minor, and the stream eventually breached the blockage. Damming and impoundment of creeks due to slumping and sloughing caused by the RIO BLANCO detonations was more extensive. No less than 24 blockages were observed after this test, and although most washed out fairly quickly, several of the dams caused temporary flooding (Whicker, Alldredge, and Hanson, 1973). This impoundment, in combination with debris- loading of the stream (also derived from slump and slough deposits), resulted in the deposition of up to $60 \mathrm{~cm}$ (two $\mathrm{ft}$ ) of silt and mud along portions of the flood plain.

3.1.11.1.4 Faults and Fractures. Although somewhat less prominent than craters and collapse sinks, faults and fractures can have a significant effect on the hydrology in the vicinity of an underground test. Significant UNE-induced displacement along faults can change the base level of an area locally, resulting in incised, abandoned, and redirected channels. Faults and fractures also can intercept drainage ways (both natural and manmade), diverting flow and/or capturing runoff. Infiltration studies of fractured alluvium in Yucca Flat have documented channels ending at, or becoming less prominent on the downstream side of fractures, as well as fractures becoming wider or more pronounced along zones or points of capture (McKinnis and Kao, 1993; Kao, Smith, and McKinnis, 1994).

Explosion-induced cracks have also been known to drain unlined reserve pits used for Yucca Flat drillholes. A concentric crack associated with the HERMOSA test (U7bs) opened during drilling of the U7bz drillhole, cracking the pit berm and draining most of the drilling fluid from the pit (Rayburn, 1989). A similar situation was encountered during drilling of the U2ef drillhole (McKinnis and Kao, 1993). These phenomena also were observed on a larger scale following the CANNIKIN test on Amchitka Island, where cracks drained four of the seven largest lakes in the vicinity (USGS, 1972). 
3.1.11.1.5 Surface Flow and Spring Discharge. In addition to influencing how surface water accumulates, test-induced changes to the morphology and physical attributes of the land surface can temporaily influence the rate at which the water moves. Pre- and post-test stream flow measurements were collected from several tests, including LONG SHOT (McKeown, et al., 1967), MILROW (USGS, 1970), CANNIKIN (USGS, 1972), SALMON (Humphreys and Taylor, 1965), and RIO BLANCO (Whicker, Alldredge, and Hanson, 1973). In each case, at least minor perturbations were observed in the flow rate, usually in the form of a surge immediately after detonation. It should be noted, however, that observations from locations in scaled proximity to tests may reflect measurement inconsistencies or incomplete data, due to damaged gaging stations or equipment.

At least one component of the prompt increase in stream flow observed after some tests is thought to be a result of compaction of water-laden, near-surface sediments. Increases in spring discharge has also been known to contribute to above-normal stream flow. Temporary increases in both the volume of discharge from individual springs, as well as the number of springs was observed after the RIO BLANCO test (Whicker, Alldredge, and Hanson, 1973).

UNEs also can have the opposite effect on spring discharge. The Constantine Spring on Amchitka Island was monitored before and after the MILROW detonation. This spring exhibited a short-term decrease in discharge, as well as increased turbidity for several days following the test (USGS, 1970). Another example of a UNE-induced hydrogeologic effect was observed at the NTS. The E-tunnel complex within Rainier Mesa encountered perched and semiperched water within zones from which nearby springs emanate. This tunnel system acted as a drain until the LOGAN test, when flow ceased (Clebsch, 1960). It was speculated that explosion-induced fractures diverted flow by allowing groundwater to drain vertically, rather than laterally through the tunnel complex (Clebsch, 1960). Although spring discharge was not affected in this case, under similar circumstances it should not be unexpected.

\subsubsection{Miscellaneous Hydrologic Effects}

A number of other hydrologic effects have also been observed following underground nuclear tests. Most of these effects have been observed in conjunction with the RIO BLANCO test in Colorado and the Amchitka Island tests (LONG SHOT, MILROW, and CANNIKIN), presumably because the test parameters and hydrogeologic setting were favorable to the 
formation of such features. These effects include several features related to the expulsion of fluids at the ground surface, such as mud and water geysers, sand boils, and mud seeps.

3.1.11.2.1 Geysers. Geysers of water and mud developed shortly after zero time of all three Amchitka tests. Geysers were reported as far away as $610 \mathrm{~m}$ from the LONG SHOT SGZ, and were observed as far away as $1300 \mathrm{~m}$ from the MILROW SGZ. Descriptions of geysers from real-time aerial observations and photography indicate that they developed in a mostly linear fashion along stream channels, within lakes, and along beaches (McKeown, et al., 1967; USGS, 1970; USGS, 1972). Evidence of mud and water geysers was also observed from the ground, mainly in the form of mud-splattered turf. The linear nature of some geysers suggests that fluid was ejected along faults and/or fractures that were dynamically "slammed shut" by the explosion-induced stresses.

One geyser observed along the Bering Sea coast shortly after the CANNIKIN test had an estimated height of more than $45 \mathrm{~m}$, and spouted water for about 12 seconds. This geyser also formed a conical "sand boil" at the point of expulsion. This sand boil measured $1.2 \mathrm{~m}$ high, 12 $\mathrm{m}$ wide at its base, and $6 \mathrm{~m}$ wide at its top, and was conspicuously located along the trace of a large fault (Teal Creek Fault) that extends across the island (USGS, 1972). Although this feature was definitely UNE-induced, sand boils also have been known to form naturally as a result of earthquakes (Swenson, 1959).

Geyser-like eruptions also have been cited as a suspected cause of some turf- or moss-mound disruptions observed after all three Amchitka Island detonations (Everett and Amundsen, 1975). It is thought that hydraulic eruption was severe enough to result in the ejection of "plugs" of moss or turf from some naturally occurring turf mounds, and the explosion-like disruption of others. It should be noted, however, that some scientists believe these disruptions to be a result of violent ground motion (Shacklette, Erdman, and Keith, 1970).

3.1.11.2.2 Spray Domes. Another prompt effect observed after the MILROW test at Amchitka Island was the disturbance of surface water in the form of "spray domes" (Koh and Rosencrantz, 1970; Merritt, 1973). As seen on aerial photographs, these spray domes appear as "white water" on both nearby fresh-water lakes and nearshore ocean surfaces. The distribution and intensity of this white water is patchy or uneven, and is not strictly a function of range from the detonation point. It has been hypothesized that this phenomenon is a result of test-induced surface spall and/or cavitation, and that the variable intensity and distribution are functions of the local 
bathymetry of the water bodies (Koh and Rosencratz, 1970). Spray domes are transient, and seem to leave no lasting evidence of their existence.

\subsubsection{Subsurface Hydrologic Effects}

In addition to the disruptive effects of an underground nuclear test on the surface hydrology, there are also a number of effects on the hydrology of the subsurface near a test. Although the focus of this report is primarily on surface effects, it is thought that under certain conditions (i.e., unique combinations of test parameters and hydrogeologic setting), many of these subsurface phenomena could manifest themselves, and/or influence the hydrology at the surface.

The hydrology of the subsurface near a test is affected mainly through alteration of the hydraulic properties of the overburden, which falls into two main categories: (1) modification (mostly compaction) of the original pore structure, and (2) creation or modification of fracture porosity and permeability. The latter includes fracturing due to the shock wave of the detonation, highpressure-gas fracturing (hydrofracture) near the cavity, and fracturing related to the chimneying process. Test-induced hydrologic phenomena in the subsurface observed after underground tests include, but are not limited to (1) lowered water levels within the chimney region, (2) elevated potentiometric water levels in the vicinity outside the chimney, and (3) minor, short-term pressure and temperature perturbations.

3.1.11.3.1 Hydrologic "Sinks." As discussed in Section 2.4, the upward stoping of the material above the cavity results in the formation of a rubble column or chimney above the detonation point. Along with the vertical displacement of strata, the chimneying process results in increased porosity and permeability within portions of the rubble column (Piper and Stead, 1965; Garber, 1971). As a result, water levels within the chimney region formed by an underground test can be lowered drastically following collapse, sometimes by as much as several hundred meters (Thordarson, 1985). Recharge or "infill" of water back into the chimney region begins almost immediately after collapse, taking from months to years to approach pre-test levels (cf. GREELEY [Rawson and Borg, 1970]; BILBY [Garber, 1971]; FAULTLESS [Thordarson, 1985]; and CHESHIRE [Erikson, 1990]). It should be noted that elevated temperatures from a UNE may inhibit the inflow of water back into portions of the cavity and chimney region.

3.1.11.3.2 Water "Mounds." In addition to the formation of a hydraulic "sink" within the chimney region, some UNEs have resulted in elevated water levels in nearby boreholes outside the chimney column. Elevated water-level tags, sometimes as much as hundreds of meters above 
pre-shot levels and as far as several hundred meters away from detonation points have been reported. The effects of this phenomenon, commonly termed "water mounding," were observed in boreholes near several NTS tests, including AARDVARK (Garber, 1963), BILBY (Hale, Winograd, and Garber, 1963), and SANDREEF, ALEMAN, GASCON, and TAHOKA (Hawkins, Cavazos, and Thompson, 1987), and offsite near the FAULTLESS test in central Nevada (Thordarson, 1985).

Several theories have been advanced to explain the exact nature and formation mechanism(s) of water "mounds" (Knox, Rawson, and Korver, 1965; Reed, 1970; Davis, 1971). Recent efforts to model this phenomenon indicated that at least part of the mounding effect is due to inelastic compaction and subsequent overpressurization of the pores within the overburden (Burkhard and Rambo, 1991). Consequently, the region of overpressurization and elevated potentiometric water levels is thought to correspond to the region affected by compaction, which varies depending on the device yield and rock strength. It is thought that in areas where the water table is at shallow depths, this overpressurization could manifest itself at the surface in the form of seeps or dynamic ejection along faults or fractures (as at Amchitka).

Not only can overpressurization result in an elevated potentiometric water surface, it can also challenge the integrity of casing or liner in nearby boreholes. Several boreholes within the "Tuff-Pile" area of Yucca Flat developed ruptured and leaking liners, or had water flowing up and over the top of their liner into the borehole (Hawkins, Cavazos, and Thompson, 1987). This "mounding" effect diminishes over time, as water flow acts to return pressures to an equilibrium condition. The rate at which the elevated potentiometric water level drops depends primarily on the transmissivity of the overburden after the test, generally taking from months to years to return to pre-shot levels.

\subsection{ECOLOGICAL EFFECTS}

Like geologic and hydrologic effects, ecological effects from a UNE are influenced by numerous factors. Effects may be dramatic or subtle, immediate or delayed, and of short or long duration. In addition, UNE-induced effects may be mixed and/or mingled with effects from other testrelated activities, such as construction, drilling, or mining operations. This section presents a cursory examination of some of the prompt, non-radiological effects of UNEs on the ecology (herein known as ecological effects), focusing on some of the effects that might be observed and 
recognized in the short term by earth scientists mapping surface effects or participating in on-site inspection activities. This section is not meant to be an in-depth investigation of cause-effect relationships, but rather a summary of mostly qualitative observations and inferences from past tests. It is hoped that this summary will emphasize the diversity of ecosystems at different locations, and the subsequent diversity of the effects upon them.

Because many ecological effects are a result of the same UNE-induced phenomena that produce geologic and hydrologic effects described in the preceding section (Section 3.1), their recognition lends valuable clues to the nature and timing of UNE-induced processes, and is an integral part of a thorough surface-effects characterization. Because of the diverse nature of ecological effects, detailed ecological analyses should be conducted by scientists who are both knowledgeable about UNE-induced effects (and their documentation) and familiar with the ecological setting of the area in question.

\subsubsection{Previous Ecological Effects Investigations}

The ecological effects of nuclear testing at the NTS have been investigated by numerous researchers, beginning in the late 1950s. Early studies emphasized radiological effects, with only brief mention of non-radiological effects (Shields and Rickard, 1959, 1960; Shields and Wells, 1962, 1963; Jorgensen, Allred, and Beck, 1963; Allred, Beck, and Jorgensen, 1965; Cannon, et al., 1981). More recent reports have presented results of broad-based ecological studies at the NTS, including the effects of both test- and non-test-related operations (Hunter, 1992, 1994a, 1994b, 1994c, and 1995). Investigations dealing strictly with the prompt, non-radiological effects of underground testing at the NTS include Tueller and Bruner (1973) and Rhoads (1976).

Non-radiological effects on the ecology of some test locations outside the.NTS also have been investigated. The most comprehensive ecological investigations were conducted in association with the Amchitka Island tests (LONG SHOT, MILROW, and CANNIKIN) in Alaska (Kirkwood, 1970; Merrit, 1970, 1971, 1973; Kirkwood and Fuller, 1972; Everett and Amundsen, 1975; Wright, 1971a, 1971b). Extensive ecological studies were also conducted in association with the RIO BLANCO test in Colorado (Whicker, Alldredge, and Hanson, 1973; Whicker, 1975) and to a lesser extent for the FAULTLESS test in central Nevada (Tueller, Bruner, and Davis, 1972; Tueller, Bruner, Everett, and Davis, 1974). Ecological effects and the phenomena that produce them also were investigated for use in the detection of underground 
nuclear tests (Erdman, 1968a, 1968b; Newcombe, 1964; Shacklette, 1966a, 1966b, 1967; Shacklette, Erdman, and Keith, 1970).

\subsubsection{Factors Influencing Ecological Effects}

Like geologic and hydrologic effects, test parameters and the local geologic and topographic setting play a major role in the type and severity of ecological effects observed after a UNE. The variety and magnitude of effects also can be influenced by characteristics or attributes of individual species, communities, and the ecosystem as a whole. These considerations include factors such as population density, pre-existing condition, range, mobility, diversity, and phenology, as well as resilience and adaptability to test-induced conditions. Characteristics such as these are particularly important in how the more subtle or indistinct effects are manifested. Factors that could exacerbate conditions by further stressing populations include natural phenomena such as post-shot weather/microclimate (and associated conditions), fire, infestations, etc., as well as human disturbances such as post-shot activities.

Although the ecological effects of underground tests can be grouped in several ways, for this report they are divided into three categories: (1) prompt behavioral effects, (2) prompt injury and mortality, and (3) alteration or damage of habitat.

\subsubsection{Prompt Behavioral Effects}

It is thought that, although prompt behavioral responses of animals could vary widely, they are probably dominated by basic, instinctual defensive tactics. Responses observed after the RIO BLANCO test included increased alertness, herding tendencies, vocalization (distress calls), fleeing (taking flight, running to or from homes, etc.), nest abandonment, and agitated or excited behavior (Whicker, Alldredge, and Hanson, 1973). Another interesting observation noted shortly after the test indicated that predatory species of birds began actively soaring and hunting shortly after detonation. It has been speculated that the combination of ground motion and increased activity of prey caused this unique response (Whicker, Alldredge, and Hanson, 1973). Because these behaviors are mostly transient, short-term responses, they probably do not leave much lasting evidence of their occurrence, but are mentioned here for completeness. 


\subsubsection{Injury or Mortality}

Underground nuclear tests have the potential to cause injury or death to nearby organisms in two primary ways. First, injury and/or mortality can be a direct result of phenomena associated with the passage of the explosion-induced shock wave. This shock wave is manifest at the earth's surface (especially within the spall zone) in two ways: (1) violent ground motion or "ground shock," and (2) pressure pulses or overpressures (both above ground and below water) initiated by the ground shock. Injury and death also can result indirectly from secondary phenomena or conditions induced or triggered by the test, such as surface collapse, landslides, rock fall, etc.

A wide variety of injuries to different organisms have been observed after underground tests. These injuries range in severity from relatively minor damage that is often difficult or impossible to detect by field observation, up to and including death. As might be expected, the more severe injuries resulted from tests with relatively high yields (and subsequently large ground shocks): In addition, tests conducted in areas with high topographic relief also have the potential for more severe ecological effects, mainly because they are more prone to secondary phenomena such as rock fall and landslides. Table 3-1 presents a summary of UNE-induced effects or phenomena, along with the ecological impacts observed or inferred from them. It should be noted that no plant or animal population has ever been endangered as a result of the effects of underground nuclear testing.

The effects of test-induced underwater overpressures on aquatic wildlife (especially sea otters) were a concern during the Amchitka Island tests. Different species of marine life were subjected to artificially generated underwater overpressures to see how the sea otters inhabiting Amchitka might be affected by underground tests (Wright, 1971). In addition, individual sea otters kept in controlled areas were observed before, during, and after the tests. Although no adverse effects to sea otters were observed after MILROW (Merrit, 1970), a number of dead and injured sea otters, as well as a noticeable reduction in the overall sea otter population were observed following the CANNIKIN test (Kirkwood and Fuller, 1972; Estes and Smith, 1973; Merrit, 1973). Other species that were injured or killed as a result of underwater overpressures from CANNIKIN included seals, birds, and both marine and freshwater fish. It should be noted that some of these deaths were thought to be at least partially a result of injuries due to violent ground motions.

The prompt ecological effects resulting from ground motion after the RIO BLANCO test in Colorado were exhaustively studied (Whicker, Alldredge, and Hanson, 1973). This report 
Table 3-1. Summary of effects/phenomena and related ecological impacts observed after underground nuclear explosions (p. 1 of 2).

\begin{tabular}{|c|c|c|c|}
\hline Effect/Phenomenon & Ecological Impact & Test Examples & References \\
\hline $\begin{array}{l}\text { Underwater } \\
\text { overpressures }\end{array}$ & $\begin{array}{l}\text { Animals: Prompt injury/death of sea otters, seals, marine and fresh water fish, } \\
\text { and diving birds; impact on food-chain relationships unknown. }\end{array}$ & $\begin{array}{l}\text { LONG SHOT } \\
\text { MILROW } \\
\text { CANNIKIN }\end{array}$ & Kirkwood \& Fuller, 1972 \\
\hline Ground shock & $\begin{array}{l}\text { Plants: increased plant litter, shock damage, sheared roots, broken limbs, more } \\
\text { severe damage to mature individuals and species that have large, above-ground } \\
\text { inertial masses; small submersed aquatic plants uprooted from lakebeds. } \\
\text { Animals: direct injury/death of fish and birds; abandonment/damage of bird } \\
\text { nests; collapse of animal burrows resulting in prompt injury/death or loss of } \\
\text { habitat, direct injury/death of sea otters. }\end{array}$ & $\begin{array}{l}\text { BOXCAR BENHAM } \\
\text { FAULTLESS } \\
\text { LONG SHOT } \\
\text { MILROW } \\
\text { CANNIKIN } \\
\text { RIO BLANCO }\end{array}$ & $\begin{array}{l}\text { Rhoads, } 1976 \\
\text { Rhoads, } 1976 \\
\text { Tueller, et al, } 1974 \\
\text { Kirkwood \& Fuller, } 1972 \\
\text { Whicker, Alldredge, \& Hanson, } 1973\end{array}$ \\
\hline $\begin{array}{l}\text { Collapse sink } \\
\text { formation }\end{array}$ & $\begin{array}{l}\text { Plants: damage, dislodgement (especially along rim of sink), disruption of soil; } \\
\text { alteration of surface hydrology. } \\
\text { Animals: injury/death during collapse. }\end{array}$ & $\begin{array}{l}\text { BOXCAR } \\
\text { FAULTLESS }\end{array}$ & $\begin{array}{l}\text { Rhoads, } 1976 \\
\text { Tueller, Bruner, \& Davis, } 1972\end{array}$ \\
\hline $\begin{array}{l}\text { Rock spall/rock fall/ } \\
\text { landslide }\end{array}$ & $\begin{array}{l}\text { Plants: vegetation damage: "boulder scars", sheared roots, dislodgement, broken } \\
\text { limbs, burial; course changes and temporary damming/impoundment of streams. } \\
\text { Animals: damaged, destroyed, and abandoned bird nests and eggs; destroyed } \\
\text { rat dens, injury/death of birds and sea otters, loss of habitat and food. }\end{array}$ & $\begin{array}{l}\text { GREELEY } \\
\text { ALMENDRO } \\
\text { CANNIKIN } \\
\text { FAULTLESS } \\
\text { RIO BLANCO } \\
\text { CANNIKIN }\end{array}$ & $\begin{array}{l}\text { Tueller \& Clark, 1976; Tueller \& Bruner, } \\
1973 \\
\text { Everett \& Amundsen, } 1975 \\
\text { Whicker, Alldredge, \& Hanson, } 1973\end{array}$ \\
\hline Slumping/sloughing & $\begin{array}{l}\text { Plants: vegetation damage; dislodgement, burial, exposed substrate; can also } \\
\text { result in temporary damming/impoundment and/or course changes of streams. } \\
\text { Animals: damage/destruction of habitat, especially small burrowing animals. }\end{array}$ & $\begin{array}{l}\text { RIO BLANCO } \\
\text { CANNIKIN } \\
\text { RIO BLANCO }\end{array}$ & $\begin{array}{l}\text { Whicker, Alldredge, \& Hanson, } 1973 \\
\text { Kirkwood \& Fuller, } 1972 \\
\text { Everett \& Amundsen, } 1975 \\
\text { Whicker, Alldredge, \& Hanson, } 1973\end{array}$ \\
\hline Fractures/faults & $\begin{array}{l}\text { Plants: vegetation damage: sheared roots, dislodgement, disruption of substrate; } \\
\text { preferential revegetation along cracks; change in soil moisture regimes. }\end{array}$ & $\begin{array}{l}\text { FAULTLESS } \\
\text { CANNIKIN }\end{array}$ & Everett \& Amundsen, 1975 \\
\hline Pressure ridges & Plants: tilted and overturned trees. & HALFBEAK & Barosh, 1967 \\
\hline Dust & $\begin{array}{l}\text { Plants: settling dust blanket ranging from minor "dusting" to complete burial of } \\
\text { vegetation, depending on ground conditions; impact uncertain. }\end{array}$ & $\begin{array}{l}\text { French tests in } \mathrm{N} \text {. } \\
\text { Africa }\end{array}$ & Faur'e, 1970 \\
\hline Disturbed ground & $\begin{array}{l}\text { Plants: exposed/damaged substrate, cracked, disrupted, and "fluffed" turf. } \\
\text { Animals: damaged gopher and ant mounds; coliapsed/damaged animal burrows. }\end{array}$ & $\begin{array}{l}\text { RIO BLANCO } \\
\text { LONG SHOT } \\
\text { MILROW } \\
\text { CANNIKIN } \\
\text { GASBUGGY } \\
\text { FAULTLESS }\end{array}$ & $\begin{array}{l}\text { Whicker, Alldredge, \& Hanson, } 1973 \\
\text { Kirkwood \& Fuller, } 1972 \\
\text { Everett \& Amundsen, } 1975 \\
\text { Shacklette, Erdman, \& Keith, } 1970\end{array}$ \\
\hline
\end{tabular}


Table 3-1. Summary of effects/phenomena and related ecological impacts observed after underground nuclear explosions (p. 2 of 2).

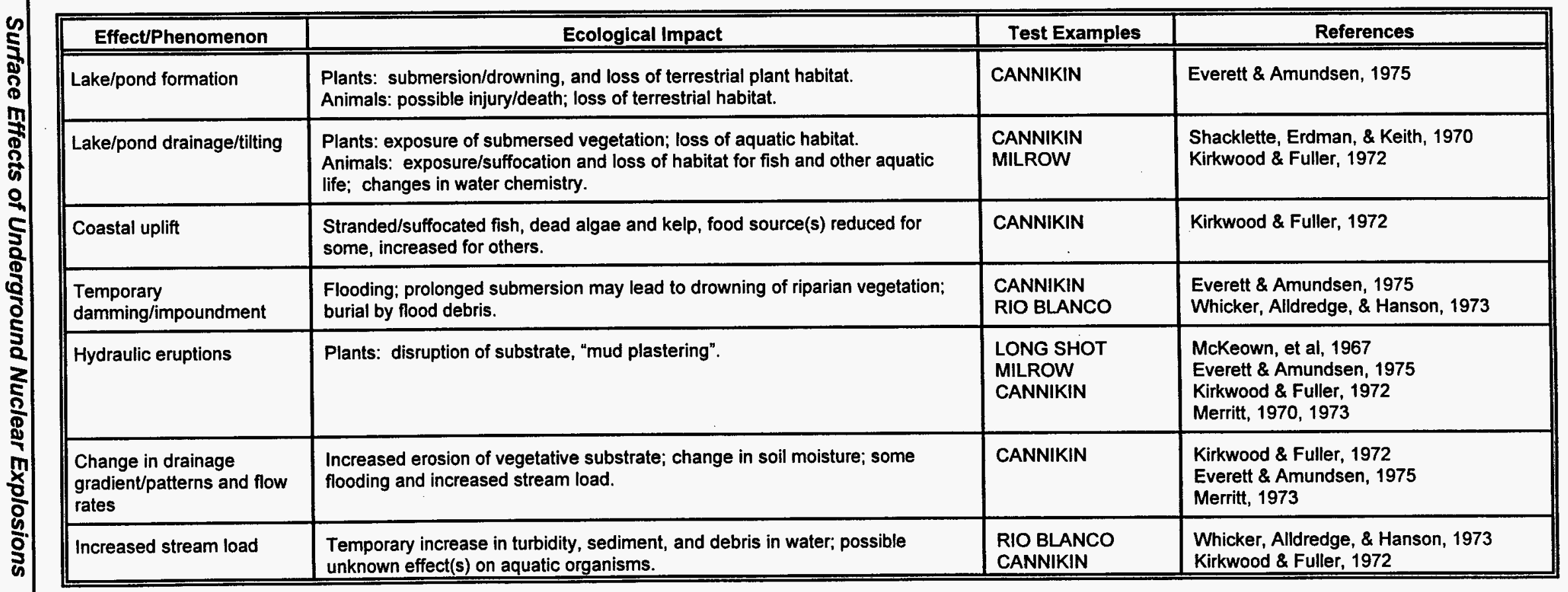


indicated that, while no dead or injured animals were found, there were undoubtedly deleterious effects to small, burrowing animals. It is thought that many individuals (especially bank swallows) were crushed or suffocated after their burrows collapsed.

At the NTS, the most noticeable type of injury and mortality from UNEs was vegetation damage due to collapse sink formation and the combination of rock spall and rock fall. Most vegetation damage associated with collapse sinks was concentrated along the edges of the sinks where disruption of the substrate due to cracking was prevalent (Rhoads, 1976). This damage was most discernable near large collapse sinks whose rims were far removed from other test-related disturbances. The effects of rock spall and rock fall were most apparent on Pahute Mesa. Here, a combination of high-yield tests (and subsequent severe ground motion) and steep topography contributed to vegetation damage along the mesa and canyon edges. This "edge effect" typically was exhibited as downed; delimbed, and uprooted trees, in some instances, for considerable distances away from the test SGZ (Tueller and Bruner, 1973; Rhoads, 1976).

\subsubsection{Alteration or Damage of Habitat}

In addition to the potential for causing injury and death to nearby organisms, an underground nuclear explosion may also alter or damage the habitat of some organisms. Like injury and mortality, disturbances to habitat occur either directly as a result of passage of the shock wave, or indirectly through secondary explosion-induced phenomena. Shock effects observed after underground tests include disturbances such as damaged bird nests (especially for cliff or bank nesters), collapsed animal burrows, and even damaged ant mounds (Table 3-1). As mentioned above, it is believed that the collapse and/or burial of animal burrows also can result in the crushing or suffocation of inhabitants.

Indirect effects of UNEs can have perhaps the greatest effect on habitats within a nearby ecosystem. Some of the more dramatic habitat disturbances observed have been a consequence of test-induced alterations of surface hydrology. These were especially evident after the CANNIKIN test, which resulted in both the creation and destruction of lacustrine environments (as described in Section 3.1.11). The drainage of pre-existing ponds appears to have been more destructive, resulting in the death of numerous aquatic organisms, including fish, zooplankton, and formerly submersed lakebed vegetation (Merritt, 1973). Another secondary effect that had prominent but temporary ecological consequences was the uplift of an approximately two 
kilometer long portion of the Bering Sea coastal intertidal zone. A similar phenomenon was observed after the MILROW test (albeit at a smaller scale), and although some marine organisms were exposed and subsequently died, there was a succession or shift of environments seaward (Kirkwood and Fuller, 1972).

Stream habitats near the RIO BLANCO and Amchitka test locations also were altered somewhat through several indirect processes. Sloughing and slumping, accompanied by minor streamcourse changes and flooding altered some riparian habitats, at least temporarily (Whicker, Alldredge, and Hanson, 1973; Everett and Amundsen, 1975). Whicker, Alldredge, and Hanson (1973) reported that flooding near the RIO BLANCO site caused deposition of substantial amounts of flood debris (silt and mud) that buried portions of the floodplain, and resulted in the temporary loss of riparian habitat and food sources. This report also stated that debris from sloughing, rock fall, and dislodged vegetation deposited within dry ravines in the area was expected to contribute heavily to siltation of main creeks following subsequent spring runoffs and heavy rains.

\subsection{CULTURAL-FEATURE EFFECTS}

In addition to geologic, hydrologic, and ecological effects, underground nuclear explosions have the potential to affect man-made or "cultural features" as well. Cultural features can include many different types of objects, including components of infrastructure (roads, bridges, dams, utility structures, etc.); buildings (commercial, industrial, institutional, and residential); underground and underwater structures and utilities (tunnels, shafts, drillholes, pipelines); testrelated features (towers, trailers, etc.); and features of special interest such as historic sites or landmarks. The following is a brief overview of some of the different types of cultural-feature damage resulting from UNEs, and some of the factors that contribute to them. As with the previous section, this overview is not meant to be an in-depth investigation of cause and effect relationships, but rather is a synopsis of the types of features that might be seen during post-test mapping or on-site inspection activities. As with the other types of effects, recognition and accurate interpretation of damage or alteration of cultural features adds valuable clues in the determination of extent and magnitude of ground motion. 


\subsubsection{Previous Cultural-Feature Effects Investigations}

For U.S. underground nuclear tests, the focus of most cultural-feature effects investigations was structural response to explosion-induced ground motion. As part of the U.S. Atomic Energy Commission (now U.S. Department of Energy) underground nuclear testing program (in particular, the Seismic Safety Support Program), the primary objectives of these investigations were to minimize damage to public and private structures, and ensure the safety of nearby populations. Toward this end, DOE contracted with several consultant organizations, including: Roland F. Beers, Inc. (later ERC); John A. Blume \& Associates, Research Division (later URS/John A. Blume \& Associates, Engineers [Blume]); the U.S. Coast and Geodetic Survey's Special Projects Party (USC\&GS); the U.S. Geological Survey (USGS); and the U.S. Bureau of Mines. Under the scientific management of Sandia National Laboratories, these contractors fielded instrumentation, collected seismic data, conducted structural response investigations, performed damage predictions and assessments, and conducted numerous special studies. This effort resulted in a large number of published reports and technical/scientific journal articles. Two notable reports that contain comprehensive overviews of both the Seismic Safety Support Program and individual tests were produced by ERC (1974) and Blume (1993). In addition, a summary of ground motion-induced effects on structures and facilities is given by Cauthen (1964), and an excellent overview of shock effects on both surface and subsurface structures is presented by Glasstone and Dolan (1977). Much of the summary information contained herein was gleaned from these reports.

The effects of UNEs on cultural features also has been documented to a certain extent through other post-shot investigations or damage surveys. These typically involved "near-field" damage surveys of neighboring test equipment and infrastructure facilities by DOE contractor personnel. An overview of this type of near-test damage was compiled by Bechtel Nevada (1996) in an attempt to catalog such features for treaty verification purposes. In addition, damage to cultural features also was sometimes mentioned, albeit briefly, in many geologic surface effects reports and memoranda.

\subsubsection{Factors Influencing Cultural-Feature Effects}

As with other surface effects, the two primary factors influencing the type and severity of cultural-feature effects are the stimuli induced by an underground nuclear explosion and the 
nature or characteristics of the features those stimuli act upon. For cultural features in the nearfield, these stimuli can be from several sources, including passage of the initial shock wave (ground shock), subsequent ground motion, and secondary phenomena such as collapse sink formation, rock falls, and landslides. Features that are relatively far from a detonation, however, typically are affected only by ground motion (if affected at all).

As mentioned in Section 2.4, an underground nuclear explosion can generate an appreciable amount of seismic energy. Because of the complex transmission path of these seismic signals, the resultant ground motion has many different frequencies (or periods) and amplitudes of vibration. Manmade structures (buildings, towers, etc.) and the components thereof also have natural vibration characteristics. In terms of structural damage, one of the most important vibration characteristics of a structure is its longest vibration period, which varies with structure height (i.e., taller structures have longer natural vibration periods). As a result of resonance, structures tend to vibrate more readily when subjected to ground motion that exhibits periods of vibration that approach their own. Because of the diverse spectrum of vibrations associated with both natural or "manmade" ground motion, at least one vibration period from ground motion would be expected to approach one of the natural vibration periods of a nearby structure. Consequently, all structures may be expected to respond to ground motion in some way. If the stress induced by this ground motion is greater than the structure can accept, damage to the structure may occur.

As might be expected, seismic energy/signals from an underground nuclear explosion decrease in strength with distance from the detonation. However, higher frequencies (shorter periods) are absorbed or "filtered" more readily by the earth, and decrease with distance at a greater rate than lower frequencies. Changes in explosion energy also have a disproportionate effect on vibration periods, with increasing yields resulting in a greater increase of low-frequency signals than highfrequency signals. Consequently, the susceptibility to ground motion-induced damage resulting from high-yield detonations is greater for taller structures than short structures, at the same distance from a detonation (with all other factors being equal).

The surface strata upon which a structure is built also play a major role in defining the characteristics of ground motion at any given location. For ground motion prediction purposes, these strata are often categorized as either "bedrock" or "soil" (which includes all relatively unconsolidated surface materials such as alluvium, fill, etc.). Depending on their thickness, geometry, stratigraphic layering, and physical properties (density, compactability, compressional 
and shear strengths, etc.), near-surface soil layers can have dramatic, frequency-dependent effects on both incident body and surface waves. These effects are most often expressed as an amplification of ground motion within a particular frequency band, as well as an increase in ground motion duration. Measurements of ground motion from both natural (earthquakes) and manmade (UNEs) sources indicate that ground motion in soil can be as much as five to ten times greater than sites in bedrock (ERC, 1974). Under certain conditions, however, soil layers can attenuate rather than amplify surface motions. The topographic expression of an area also can have a frequency-dependant effect on ground motion (Boore, 1972; Davis and West, 1973).

The response of a given structure to ground motion also can be influenced by characteristics of the structure itself. Attributes of a structure such as design, building materials, and construction techniques play a major role in determining the vibration characteristics of a structure, such as its natural vibration period, rigidity/stiffness, and damping potential. The severity of damage also can be influenced by the pre-test condition of the structure, encompassing factors such as aging/deterioration, built-up stress (due to soil compaction or expansion, climatic conditions, etc.), and pre-existing damage (natural or otherwise). Interaction of a structures foundation and the underlying soil, or the "soil-structure system," also can affect the nature of transmitted ground motion. Structural movement induced from ground motion can cause additional stress to underlying soils which already have been stressed by the passage of seismic waves (ERC, 1974).

Some structures and equipment are "naturally" resistant to shock effects. Equipment such as wheeled vehicles and trailers often have, as part of their original design, shock absorbers, springs, and rubber tires that can lessen the effects of ground motion. Other types of equipment and structures such as field-office-type buildings can be "shock-mounted" on springs or other shock-absorbing devices and/or material to mitigate damage from ground motion. A common practice at the NTS was to mount trailers and sensitive equipment on blocks of foam and/or "corrugated" aluminum (hexel) that absorbed some of the transmitted energy of the explosion.

\subsubsection{Types of Cultural-Feature Effects}

As mentioned earlier, cultural features can include structures such as buildings and towers, or components of infrastructure such as roads, water wells, and power transmission lines. Damage to these features can range from subtle (minor cracks or displacements) to major damage and/or collapse. For structures such as buildings or towers, damage is typically categorized as either 
"architectural" or "structural". Architectural-type damage is relatively minor, typically consisting of small cracks, broken windows and fixtures, and other disruptions that do not affect structural integrity. Conversely, structural-type damage is more severe, affecting more critical elements or systems of a structure, such as load-bearing beams, columns, walls, foundations, frameworks, and supports/anchors.

Damage to other features typically has included cracked or displaced roads, pads or other prepared surfaces, downed or displaced fences and power lines, cracking and compaction over culverts and bridge abutments, and damaged or displaced field equipment.

Damage to drillholes and associated equipment also was identified after several underground tests. Stresses induced by these detonations caused sloughing/caving of open boreholes, cracking/rupturing of wellheads and casings, damaged downhole pumps, water-production declines, and increased sediment contamination. As mentioned in Section 3.1.11, damage also can result indirectly from hydrologic effects, such as cracked/ruptured well casings and liners due to overpressurization of the aquifer. In addition, increases in water turbidity and system contamination (rust, sediment, etc.) were reported after several tests, both on and off the NTS, including SALMON (Taylor, 1966), STERLING (Taylor and Oakley, 1971), and HANDLEY (USGS, 1971). 


\subsection{DISCUSSION}

\subsection{APPLICATIONS}

The effort to document and understand surface effects of UNEs has been beneficial to several applications. For the U.S. Weapons Testing Program, this understanding has benefited two main areas of interest: (1) test siting, and (2) containment. Detailed surface effects maps have allowed planners to make more informed decisions on test and equipment locations, especially with regard to avoidance of potentially detrimental features (mainly faults and sinks). As mentioned in Section 3.1.11.1.4, cracks also can have costly and time-consuming effects on drilling operations. Surface effects also have led to better understanding of geologic and test-related mechanisms or processes, such as differential compaction, chimney and collapse sink formation, fault movement, and spall. By aiding scientists in the identification of obscure surface and subsurface features (mainly buried faults or scarps) that might adversely affect the containment of radionuclides, the documentation of surface effects has led to more thorough (and presumably better) geologic and containment characterizations. Because of its relevance to containment issues, the analysis of surface effects became an increasingly important part of site and test evaluation. In recognition of this importance, a Containment Evaluation Panel (CEP) Data Needs Subcommittee report recommended that, where available, areal subsidence measurements and surface effects maps (with appropriate narrative analysis) be included in the main text of every containment prospectus document submitted to the CEP for evaluation (Twenhofel, et al., 1983).

A firm understanding of the surface effects of underground nuclear explosions--their significance and proper interpretation--is important for the development and negotiation of nuclear test treaty protocols. Furthermore, because on-site inspection is generally regarded as an important element of treaty verification, procedures developed for the proper recognition and documentation of surface effects also should prove beneficial for training and fielding of on-site inspection teams (Hawkins and Wohletz, 1995). 


\subsection{ALLOWANCES AND LIMITATIONS}

As one might expect, identification and subsequent interpretation of surface effects is not always a simple process. Because surface effects are dependent upon characteristics of both the test and the location, they can be exhibited in many different ways and to many different degrees. Conclusions based on the presence (or absence) and/or character of surface effects should be made with these variables in mind. The following sections present several of the main limitations or caveats associated with surface effects interpretations.

\subsubsection{Presence and Magnitude of Surface Effects}

Underground nuclear explosions do not necessarily result in surface effects. Because the presence and magnitude of effects are very dependent on test parameters, overburied or low-yield tests may result in faint or undistinguishable surface effects, or possibly no surface manifestation at all. The presence and magnitude of effects is also very dependent on the physical setting of the test location; topography, vegetation, climate and weather, geology, and hydrology all play a major role in how surface effects are exhibited or expressed. In addition, some surface effects can fade, or be obscured or obliterated because of the effects of time, weather, and post-shot activities. Furthermore, rogue nations or organizations wishing to conduct clandestine tests could employ measures to conceal, obliterate, obscure, or even move evidence of surface effects.

It also should be mentioned that many of the specific examples of surface effects cited in Section 3.0 of this report were the most dramatic or spectacular examples for which documentation exists. In addition, the examples cited are derived from only a few test locations (mostly from the NTS). Consequently, while not intended, there may be some bias in the balance of features discussed. This is not to say that these examples are not representative of the types of effects observed, or that surface effects (real or expected) from other locations should be drastically different; but rather that tests conducted at other locations under different conditions may not produce effects of the same magnitude (size, extent, etc.) as the examples cited herein.

As mentioned in Section 3.0, recognition of several types of geologic surface effects is aided by pre-test knowledge and/or familiarity with the test location. This is especially true of the more subtle features, such as disturbed ground. Pre-test elevation surveys are also helpful in recognition of changes in the surface morphology of a test location, especially in areas with 
rugged terrain or dense ground cover. Pre-test surveys also are recognized as an integral part of ecological and cultural-feature effects investigations as well.

From a CTBT perspective, none of the effects described herein are by themselves conclusive evidence of a UNE. However, their presence and nature (distribution, severity, association with radioactivity, etc.) could possibly add valuable clues in the determination of whether a UNE has taken place. For instance, analyses of surface effects could help pinpoint the location of a clandestine test, thereby aiding investigators in the detection of related seismic activity. Analyses of surface effects also can aid in the identification of preferential pathways for gases generated by the detonation, allowing more accurate placement of radionuclide detection equipment. In addition, surface effects might also aid in gross estimates of yield and/or depth of burial of UNEs. Any surface effects analyses, however, are based on the assumptions that (1) surface effects exist, and (2) that investigators can delimit an area of reasonable size wherein surface effects might be recognized within the parameters of an inspection (based on information from other sources, such as remotely sensed data).

\subsubsection{Natural Counterparts of Surface Effects}

Many of the surface effects described in Section 3.0 of this report have natural counterparts-effects which are similar, but are a result of natural phenomena or processes. Some of these processes or phenomena and the resultant effects are presented in Table 4-1. Many of the effects listed are very similar in nature to UNE-induced effects (especially those resulting from earthquake-induced ground motion), however, differences between natural and UNE-induced effects have not been summarily investigated, and the list presented may be incomplete. Furthermore, it is highly recommended that any interpretation of the genesis of surface effects (natural versus "manmade") include determination of whether any such natural process(es) are possible at a particular location, and if so, the probability of occurrence (alone, or in combination with other visible phenomena).

It also should be mentioned that surface effects of UNEs can have other manmade counterparts, namely, the effects of underground conventional explosions. Many of the effects of both conventional and nuclear underground explosions are very similar, however, discussion of this 
Table 4-1. Geologic surface effects that have natural counterparts.

\begin{tabular}{|c|c|}
\hline Surface Effect & $\begin{array}{l}\text { Natural counterpart(s) and the phenomena or } \\
\text { process(es) that cause them }\end{array}$ \\
\hline Craters & Meteorite impact crater \\
\hline Collapse sinks & Karst-type collapse or "sinkholes" \\
\hline Depressions/domes & Geomorphologic or structural features \\
\hline $\begin{array}{l}\text { Faults/fractures } \\
\text { (linear) }\end{array}$ & Faults, fractures, and joints from natural tectonic stresses \\
\hline Rock spall & $\begin{array}{l}\text { Mass-wasting and weathering processes; ground motion from } \\
\text { earthquakes }\end{array}$ \\
\hline Mass movement & $\begin{array}{l}\text { Natural rock fall, landslides, and sloughing/slumping triggered } \\
\text { and/or exacerbated by natural phenomena or processes. }\end{array}$ \\
\hline Pressure ridges & Pressure ridges induced by natural seismic activity \\
\hline Turf disruptions & Solifluction; gravity slides \\
\hline Dust cloud formation & $\begin{array}{l}\text { Formation due to natural phenomena such as landslides, } \\
\text { exacerbated by ground conditions and weather. }\end{array}$ \\
\hline Sand boils/geysers & $\begin{array}{l}\text { Natural hydrothermal activity; natural seismic/tectonic } \\
\text { processes }\end{array}$ \\
\hline Ground motion & Ground motion due to natural seismicity \\
\hline
\end{tabular}


topic is beyond the scope of this report. Discrimination of these effects, however, is an important issue, and should be addressed further.

\subsubsection{Determination of the Relative Age of Surface Effects}

In addition to recognition of the various types of effects, personnel documenting surface effects may have to determine the relative age of effects (i.e., are effects a result of tests conducted in the near or far past; pre- or post-CTBT). This determination may be difficult, especially in heavily used test areas that contain many old features. For this reason, accurate and complete maps of existing surface effects are essential to new mapping efforts. In addition, conditions and/or activities mentioned in Section 4.2.1 can obliterate or obscure features, making determination of relative age even more challenging. Some possible indicators of the relative age of geologic surface effects are presented in Table 4-2. Several botanical indicators of relative and absolute age also have been recognized (both individually and as a part of geologic surface effects) (Shacklette, Erdman, and Keith, 1970). As mentioned earlier, however, many interpretations involving biologic indicators should be made by personnel familiar with both surface effects documentation, and the ecosystem of the location in question (with particular emphasis on growth/revegetation and procession rates of native species).

\subsubsection{Documentation Issues}

The procedures used to document surface effects at the NTS, along with many of the rationale behind them, are provided in Appendix $\mathrm{C}$ of this report. These procedures were developed and used successfully to meet the needs and objectives of the U.S. Weapons Testing Program at the NTS. It is recognized that future needs, objectives, and working parameters may be quite different than those of the past. In addition, advances in technology and/or techniques might render some methods or equipment obsolete. Consequently, modification of these techniques may be necessary for their integration into future programs or activities.

Although efforts to document and understand surface effects have resulted in numerous reports and memoranda, it is recommended that future investigators receive field training in the recognition and documentation of these features. This training would allow investigators to view 
Table 4-2. Possible indicators of the relative age of geologic surface effects.

\begin{tabular}{|c|c|}
\hline $\begin{array}{l}\text { Type of } \\
\text { effect }\end{array}$ & Indicator or evidence of relative age \\
\hline Craters & $\begin{array}{l}\text { Extent of revegetation/plant succession; extent of crater fill; water } \\
\text { impoundment and subsequent flora and fauna succession }\end{array}$ \\
\hline Collapse sinks & $\begin{array}{l}\text { Extent of revegetation; extent of sink erosion and/or fill (water } \\
\text { and/or sediment); if impoundment of water occurs, extent of biotic } \\
\text { procession }\end{array}$ \\
\hline Cracks & $\begin{array}{l}\text { Extent of "healing" (fill, revegetation, etc) or erosion (rounding, } \\
\text { opening, and/or eroded appearance); crack orientation or patterns } \\
\text { (especially radiosymmetric cracks) can aid in distinguishing old vs. } \\
\text { new cracks; cross-cutting relationships (cracked cultural features } \\
\text { of known age) }\end{array}$ \\
\hline Rock spall & $\begin{array}{l}\text { Relative "freshness" of broken surfaces; indicators include moss, } \\
\text { lichens, rock varnish or coatings; revegetation between spalled } \\
\text { blocks and outcrop }\end{array}$ \\
\hline Mass movement & $\begin{array}{l}\text { Relative "freshness" of broken, damaged, or displaced surfaces } \\
\text { (both rock and vegetation); "healed" or revegetated boulder scars; } \\
\text { stage of vegetation reorientation or geotropism; also, relatively } \\
\text { young deposits of dust or flood deposits along fluvial environments }\end{array}$ \\
\hline Pressure ridges & Degree of compaction, healed or revegetated cracks \\
\hline Disturbed ground & Degree of compaction, degree of revegetation/procession \\
\hline
\end{tabular}


features first hand, gaining insight into: (1) the recognition of features, (2) the influences of yield, geology, topography, climate, etc., and (3) the effects of time on features. Field exercises also could be designed to allow investigators to test field equipment and documentation techniques (both old and new), and get a feel for personnel, time, and logistical requirements needed to meet various objectives under the constraints of treaty protocols. In short, this training would allow investigators to become more proficient in the identification and documentation of surface effects for future deployments. As a result, subsequent interpretations or conclusions would possibly be more definitive, reliable, and credible (real or perceived).

The NTS is a logical location for such training exercises for several reasons. First and foremost, the NTS has hosted a wide variety and number of tests in an assortment of test media and landforms, resulting in surface effects of numerous type and severity. The effects, test parameters, and physical setting are well documented and understood, and the climate of the NTS has allowed many features to be relatively well preserved. Secondly, the NTS has on-site personnel with expertise in the recognition and documentation of surface effects available to support such training exercises. In addition, the NTS also has a well-established infrastructure that could easily support such exercises. 
This page intentionally left blank. 


\subsection{SUMMARY}

- Surface effects as described herein are the disruption or alteration of the near-surface environment resulting from an underground nuclear explosion.

- $\quad$ Surface effects have been studied and documented since the inception of the U.S.

Weapons Testing Program.

- Efforts to document and understand surface effects have been beneficial for several applications: (1) test siting and planning, (2) site characterization for containment of radionuclides, and (3) negotiation and verification of nuclear test treaties.

- Most U.S. experience with surface effects was gained through underground nuclear testing at the NTS, which has hosted more UNE's than any other test site in the world.

- A working knowledge of the phenomenology of underground nuclear explosions is important in understanding the causes of surface effects.

- The type and character of surface effects resulting from UNEs are dependent upon many variables, including test parameters (configuration, yield, depth of burial), geology and hydrology (surface and subsurface), topography, vegetation cover, and climate. Under certain conditions, a UNE may result in no noticeable surface effects at all.

- Surface effects can be grouped into three main categories: (1) geologic and hydrologic effects, (2) ecological effects, and (3) cultural-feature effects. Geologic and hydrologic effects are described in detail in Section 3.1. Brief overviews of ecological and culturalfeature effects are presented in Sections 3.2 and 3.3, respectively.

- Attributes of the NTS thought to be important to the manifestation of surface effects are presented in Appendix B, and procedures used in the documentation of surface effects are presented in Appendix C 
- Natural phenomena or processes can result in features that are similar to surface effects of UNEs.

- Surface effects are valuable clues for nuclear test treaty verification purposes. Much information can be gathered remotely, and on-site inspections/mapping can provide "ground truth," as well as identify subtle or obscure features. Conclusions or interpretations based on surface effects should take into consideration the inherent limitations associated with these features.

- Field training in the recognition and documentation of surface effects would greatly benefit personnel involved in future surface effects documentation and on-site inspection efforts.

- The NTS is a logical location for surface effects field training for several reasons, including: (1) the availability of well-documented and relatively well-preserved surface effects from a wide assortment of tests and a variety of well-known geologic media, (2) on-site personnel experienced in the recognition and documentation of surface effects, and (3) built-in infrastructure/logistical support. 


\subsection{BIBLIOGRAPHY}

Allen, R. T., 1981, Differential compaction, in Hudson, B. C., Jones, E. M., Keller, C. E., and Smith, C. W., eds., Proceedings of the Monterey Containment Symposium: Los Alamos National Laboratory Report LA-9211-C, v. 2.

Allred, D. M., Beck, D. E., and Jorgensen, C. D., 1965, A summary of the ecological effects of nuclear testing on native animals at the Nevada Test Site: Proceedings of the Utah Academy of Sciences, Arts, and Letters, vol. 42, Part 2, p. 252-260.

App, F. N., 1985, Permanent displacement of the ground surface resulting from undergroundnuclear-test-induced ground shock, in Olsen, C.W., and Donohue, M.L., eds., Proceedings of the Third Symposium on Containment of Underground Nuclear Explosions: Lawrence Livermore National Laboratory Report CONF-850953, v. 2, p. 409-424.

Baldwin, M. J., and Townsend, D. R., 1995, Geotechnical source book for DNA underground weapons effects tests; Raytheon Services Nevada Report TSP:DGP:071:95.

Barosh, P. J., 1965, Preliminary joint study of the northeast border of Yucca Flat and relationships of the joints to the pattern of surface effects produced over underground nuclear explosions: U.S. Geological Survey Technical Letter NTS-139, 19 p.

Barosh, P. J., 1967, Geologic effects from an underground test at the PILE DRIVER site, Area 15, Nevada Test Site: U.S. Geological Survey Technical Letter NTS-197, 6 p.

Barosh, P. J., 1967, Geological effects from an underground explosion at the U19b site, Nevada Test Site: U.S. Geological Survey Technical Letter Special Studies-I-51, 9 p.

Barosh, P. J., 1968, Relationship of explosion-produced fracture patterns to geologic structure in Yucca Flat, Nevada Test Site, in Eckel, E. B., ed., Nevada Test Site: Geological Society of America Memoir 110, p. 199-217.

Bechtel Nevada, 1996, Comprehensive Test Ban Treaty catalog of building damage and surface indications of nuclear testing: Bechtel Nevada Report, $32 \mathrm{p}$.

Bechtel Nevada, 1996, Comprehensive Test Ban Treaty catalog of containment and test construction features for on-site inspection: Bechtel Nevada Report, $28 \mathrm{p}$.

Blankennagel, R. K., and Weir, J. E., Jr., 1973, Geohydrology of the eastern part of Pahute Mesa, Nevada Test Site, Nye County, Nevada: U.S. Geological Survey Professional Paper 712B, p. B1-B33. 
Blume (see URS/John A. Blume \& Associates, Engineers).

Boardman, C. R., 1970, Engineering effects of underground nuclear explosions: Proceedings Symposium on Engineering with Nuclear Explosives, Las Vegas, Nevada, CONF700101, vol. 1, p. 43-67.

Burkhard, N. R., and Rambo, J. T., 1991, One plausible explanation for water mounding, in Olsen, C. W., and Price, M. E., eds., Proceedings of the Sixth Symposium on Containment of Underground Nuclear Explosions: Lawrence Livermore National Laboratory Report CONF-9109114, v. 2, p. 145-158.

Cannon, H. L., Strobell, M. E., Bush, C. A., and Bowles, J. M., 1981, Effects of nuclear and conventional explosives on vegetation: U.S. Geological Survey Open-File Report 81$1300,142 \mathrm{p}$.

Carothers, J. E., and friends, 1995, Caging the dragon - The containment of underground nuclear explosions: U.S. Department of Energy Report DOE/NV-388, Defense Nuclear Agency Report DNA-TR-95-74, $726 \mathrm{p}$.

Carr, W. J., 1965, Preliminary results of subsurface investigation of fractures in Yucca Flat, Nevada Test Site: U.S. Geological Survey Technical Letter Yucca-57, 15 p.

Carr, W. J., 1974, Summary of tectonic and structural evidence for stress orientation at the Nevada Test Site: U.S. Geological Survey Open-File Report 74-176, 53 p.

Carroll, R. D., 1993, Predicting cavity volumes and height of collapse of chimneys in Rainier Mesa, Nevada Test Site, with note on the cumulative effects of shock damage (U): U.S. Geological Survey report prepared for the Defense Nuclear Agency, Nevada Operations Office, (C-FRD).

Cauthen, L. J., Jr., 1964, The effects of seismic waves on structures and other facilities: Proceedings of the Third Plowshare Symposium - Engineering with Nuclear Explosives, University of California, Davis, TID 7695, p. 207-228.

Circeo, L. J., Jr., and Nordyke, M. D., 1964, Nuclear cratering experience at the Pacific Proving Grounds: Lawrence Radiation Laboratory Report UCRL-12172, 92 p.

Clebsch, A. Jr., 1960, Ground water in the Oak Spring Formation and hydrologic effects of underground nuclear explosions at the Nevada Test Site: U.S. Geological Survey OpenFile Report TEI-759, 29 p.

Cooper, J. B., and Glanzman, V. M., 1971, Geohydrology of Project Gnome site, Eddy County, New Mexico: U.S. Geological Survey Professional Paper 712-A, p. A1-A24. 
Corchary, G. S., and Barnes, H., 1966a, Surface effects mapped in Yucca Flat, Nevada Test Site, through March 1, 1966: U.S. Geological Survey Technical Letter NTS-91, Supplement 2.

Corchary, G. S., and Barnes, H., 1966b, Surface effects mapped in Yucca Flat, Nevada Test Site, through June 30, 1966: U.S. Geological Survey Technical Letter NTS-91, Supplement 3.

Covington, H. R., 1987, Map showing features induced by underground nuclear explosions at Pahute Mesa, Nevada Test Site, Nye County, Nevada, April 1976 through December 1983: U.S. Geological Survey Miscellaneous Geologic Investigations Map I-1872, scale $1: 48,000$.

DOE (see U.S. Department of Energy).

Davis, L. L., 1968, Analysis of ground motion and containment, Sterling event: Environmental Research Corporation Report VUF-1035, 103 p.

Davis, R. E., 1962, Preliminary report on the geology of the U16a Tunnel, Nevada Test Site: U.S. Geological Survey Technical Letter Marshmallow-4, 6 p.

Davis, R. E., 1964, Summary maps of surface effects mapped in Yucca Flat, Nevada Test Site, January 1, 1964 through June 30, 1964: U.S. Geological Survey Technical Letter NTS-91 (declassified July 31,1989 ).

Davis, R. E., and Snyder, R. P., 1962, Preliminary report on the extent and character of explosion-induced fractures, Area 16, Nevada Test Site: U.S. Geological Survey Technical Letter Marshmallow-5, 6 p.

Davis, S. N., 1971, Discussion of paper by Walter E. Reed, Transport of water away from a buried heat source--with special reference to hydrologic phenomena observed at Aardvark nuclear detonation: Journal of Geophysical Research, v. 76, p. 630-634.

Deupree, R. G., Noel, S. D., and Watson, C. A., 1987, Trends in cavity collapse data, in Olsen, C. W., Donohue, M. L., and Wander, S., eds., Proceedings of the Fourth Symposium on Containment of Underground Nuclear Explosions: Sandia National Laboratory Report CONF-870961, Vol. 2, p. 430-445.

Dickey, D. D., 1965, Mechanisms involved in causing fault movement by underground explosions: U.S. Geological Survey Technical Letter NTS-153, 14 p.

Dickey, D. D., Jenkins, E. C., McKeown, F. A., and Lee, W. H., 1967, Geologic effects of the Greeley event, Nevada Test Site: U.S. Geological Report USGS-474-12, [NTS-196].4 p. 
Dickey, D. D., 1968, Fault displacement as a result of underground nuclear explosions: in Eckel, E. B., ed., Nevada Test Site: Geological Society of America Memoir 110, p. 219-232.

Dickey, D. D., and Ellis, W. L., 1968, Principle linear fractures resulting from nuclear explosion in Pahute Mesa: U.S. Geological Survey Technical Letter Special Studies-67.

Dickey, D. D., McKeown, F. A., and Ellis, W. L., 1968, Summary of geologic effects of the Boxcar event, Nevada Test Site: U.S. Geological Survey Technical Letter Special Studies-65, 4 p.

Drellack, S. L., Jr., 1988, Fenix \& Scisson post-shot surface mapping procedures: Fenix \& Scisson memo GEO-0451, Drellack to Garcia, 7 p.

Drellack, S. L., Jr., 1989, Fenix \& Scisson post-shot surface effects mapping procedures: Fenix \& Scisson Training Procedure GP-001, 8 p.

Drellack, S. L., Jr., 1994, An introduction to NTS geology and geophysical log characteristics: Raytheon Services Nevada Geologic Report, 68 p.

ERC (see Environmental Research Corporation).

Edwards, C. L., Harper, M. D., Weaver, T. A., Cash, D. J., Ray, J. M., and Homuth, E. F., 1983, Microquake activity associated with underground nuclear testing at the Nevada Test Site: Los Alamos National Laboratory Report LA-8552-MS, 19 p.

Eisler, J. D., and Chilton, F., 1964, Spalling of the earth's surface by underground nuclear explosions: Journal of Geophysical Research., vol. 69, no. 24, p. 5285-5293.

Ekren, E. B., 1968, Geologic Setting of Nevada Test Site and Nellis Air Force Range: in Eckel, E. B., ed., Nevada Test Site: Geological Society of America Memoir 110, p. 11-19.

Ellis, W. L., and Snyder, R. P., 1974, Asymmetry of collapse sinks in Yucca Flat, Nevada Test Site, Nevada: U.S. Geological Survey Report USGS-474-180, [NTS-243] 16 p.

Emerick, W. L., and Davis, R. E., 1965, Surface effects mapped in Yucca Flat, Nevada Test Site, January 1, 1964 through June 30, 1965: U.S. Geological Survey Technical Letter NTS91, Supplement 1.

Environmental Research Corporation, 1970a, Analysis of ground motions and close-in physical effects, Rulison event: Report Number NVO-1163-206 (Available from U.S. Department of Commerce, National Technical Information Service, Springfield, Virginia, 22161). 
Environmental Research Corporation, 1970b, Photo interpretation of close-in physical effects of an underground nuclear detonation: Report Number NVO-1163-TM-23, 12 p. (Available from U.S. Department of Commerce, National Technical Information Service, Springfield, Virginia, 22161).

Environmental Research Corporation, 1974, Prediction of ground motion characteristics of underground nuclear detonations: Report Number NVO-1163-239 (Available from U.S. Department of Commerce, National Technical Information Service, Springfield, Virginia, 22161).

Erdman, J. A., 1968a, The use of semi-arid vegetation in the detection of underground nuclear explosions: Project GASBUGGY Final Report, 63 p. (C-FRD)

Erdman, J. A., 1968b, The use of arid vegetation in the detection of underground nuclear explosions: Event FAULTLESS of Operation CROSSTIE, Final Report, 38 p. (C-FRD)

Erikson, S. J., 1990, Report of the drilling and radionuclide migration investigation conducted at UE20n\#1, Pahute Mesa, Nevada Test Site, 1987, Desert Research Institute Report DRI45081, Reno, Nevada.

Everett, K. R., and Amundsen, C. C., 1975, Geomorphology and plant ecology--An assessment of the impact of AEC nuclear tests on Amchitka: Battelle Columbus Laboratory Report BMI-171-152, $71 \mathrm{p}$.

Faur'e, J., 1970, Research on geologic effects of underground nuclear explosions in a Sahara granite massif: doctoral dissertation, Univ. of Nancy, [translated 1972, UCRL-TRANS10615, (pt. 1, 2, and 3)].

Foote, R. Q., Hays, W. W., and Klepinger, R. W., 1969, Analysis of ground motions and close-in physical effects, Gasbuggy event: Environmental Research Corporation Report PNE1010.

Frizzel, V. A., and Shulters, J., 1990, Geologic map of the Nevada Test Site, southern Nevada: U.S. Geological Survey Miscellaneous Investigation Series Map I-2046, scale 1:100,000.

Garber, M. S., 1963, Large rise and following decline of water level in Well 7, Area 3, Nevada Test Site, An effect from the Aardvark underground nuclear explosion: U.S. Geological Survey Technical Letter Yucca-48, $9 \mathrm{p}$.

Garber, M. S., 1971, A method for estimating effective porosity in a rubble chimney formed by an underground nuclear explosion: U.S. Geological Survey Professional Paper 750-C, p. C207-C209. 
Garcia, M. N., 1987, Photogrammetric method for determining sink volumes at the Nevada Test Site, in Olsen, C. W., Donohue, M. L., and Wander, S., eds., Proceedings of the Fourth Symposium on Containment of Underground Nuclear Explosions: Lawrence Livermore National Laboratory Report CONF-870961, v. 2, p. 446-455.

Garcia, M. N., 1989, Photogrammetric methods applied to surface mapping and volumetric studies at the Nevada Test Site, Nevada: Photogrammetric Engineering and Remote Sensing, v. 55, no. 8, p. 1197-1201.

Garcia, M. N., Drellack, S. L., Jr., and McKinnis, W. B., 1989, Field and photogrammetric procedures for mapping surface effects produced by subsurface nuclear testing at the Nevada Test Site, Nye County, Nevada: U.S. Geological Survey unpublished Open-File Report (draft).

Gard, L. M., 1963, Nuclear explosions--Some geologic effects of the Gnome shot: Science, v. 139 , no. 3558 , p. $911-914$.

Germain, L. S., and Kahn, J. S., 1968, Phenomenology and containment of underground nuclear explosions: Lawrence Radiation Laboratory Report UCRL-50482, 49 p.

Glasstone, S., and Dolan, P. J., 1977, The Effects of Nuclear Weapons (third edition), U.S. Department of Defense and the Energy Research and Development Administration, U.S. Government Printing Office, Washington, D. C., 653 p.

Gonzalez, D. D., and Wollitz, L. E., 1972, Hydrological effects of the CANNIKIN event: Bulletin of the Seismological Society of America, v. 62, no. 4, p. 947-957.

Gonzalez, D. D., Wollitz, L. E., and Brethauer, G. E., 1974, Bathymetry of Cannikin Lake, Amchitka Island, Alaska, with an evaluation of computer mapping techniques: U.S. Geological Survey Report USGS-474-203, 24 p.

Hakala, W. W., 1968a, Craters and cavities formed by underground nuclear explosions, Volume I (U): Sandia Laboratories Plowshare Report SC-RR-68-140 (C-FRD).

Hakala, W. W., 1968b, Craters and cavities formed by underground nuclear explosions, Volume II. Index of events and classified contour maps (U): Sandia Laboratories Plowshare Report SC-RR-68-141 (C-FRD).

Hakala, W. W., 1969, Effects of material properties on surface and subsurface subsidence upon collapse of an underground cavity (U): Environmental Research Corporation Report NVO-1163-171 (C-FRD).

Hakala, W. W., 1970, Subsidence caused by an underground nuclear explosion, in, Proceedings Symposium on Engineering with Nuclear Explosives: American Nuclear Society and U.S. Atomic Energy Commission Report CONF-700101, vol. 2, p. 1428-1455. 
Hale, W. E., Winograd, I. J., and Garber, M. S., 1963, Preliminary appraisal of close-in aquifer response to the Bilby event, Yucca Flat, Nevada: U.S. Geological Survey Technical Letter NTS-63, $32 \mathrm{p}$.

Hale, G. S., Trudeau, D. A., and Savard, C. S., 1995, Water-level data from wells and test holes through 1991 and potentiometric contours as of 1991 for Yucca Flat, Nevada Test Site, Nye County, Nevada: U.S. Geological Survey Water-Resources Investigations Report 95-4177, 1 sheet, scale 1:48,000.

Harril, J. R., Gates, J. S., and Thomas, J. M., 1988, Major ground-water flow systems in the Great Basin region of Nevada, Utah, and adjacent states: U.S. Geological Survey Hydrologic Investigations Atlas HA-694-C, 2 sheets, scale 1:1,000,000.

Hawkins, W. L., Cavazos, A. P., and Thompson, P. H., 1987, Geologic and hydrologic investigations at the Aleman (U3kz) site, and other sites in Yucca Flat, the Nevada Test Site, in Olsen, C. W., Donohue, M. L., and Wander, S., eds., Proceedings of the Fourth Symposium on the Containment of Underground Nuclear Explosions: Sandia National Laboratory Report CONF-870961, v. 2, p. 387-398.

Hawkins, W. L., 1983, Review of surface effects from underground nuclear explosions near the Yucca Fault, Nevada Test Site, in Olsen, C.W., compiler, Proceedings of the Second Symposium on the Containment of Underground Nuclear Explosions: Lawrence Livermore National Laboratory Report CONF-830882, v. 3, p. 115-137 (SRD).

Hawkins, W. L., and Wohletz, K. H., 1995, Visual inspection for CTBT verification: Los Alamos National Laboratory Report (Draft), 28 p.

Higgins, G. H., 1970, Underground nuclear tests, in Proceedings - Symposium on Engineering with Nuclear Explosives: American Nuclear Society and U.S. Atomic Energy Commission Report CONF-700101, vol. 2, p. 1428-1455.

Holzer, F., 1968, Gasbuggy preliminary postshot report: Lawrence Radiation Laboratory Report UCRL-50386, [PNE-1003] $16 \mathrm{p}$.

Houser, F. N., and Eckel, E. B., 1962, Possible engineering uses of subsidence induced by contained underground nuclear explosions, in U.S. Geological Survey Research 1962: U.S. Geological Survey Professional Paper 450-C, p. C17-C18.

Houser, F. N., 1969a, Variation of collapsed chimney height with depth of burial of nuclear tests, Nevada Test Site: U.S. Geological Survey Report USGS-474-22 (C-FRD).

Houser, F. N., 1969b, Subsidence related to underground nuclear explosions, Nevada Test Site: Seismological Society of America Bulletin, vol. 59, no. 6, p 2231-2251. 
Houser, F. N., 1970a, A summary of information and ideas regarding sinks and collapse, Nevada Test Site: U.S. Geological Survey Report USGS-474-41 [NTS-216], 123 p.

Houser, F. N., 1970b, Sequence of surface movement and fracturing during sink subsidence, Nevada Test Site: U.S. Geological Survey Report USGS-474-56 [NTS-219], 38 p.

Houser, F. N., 1970c, Near-surface sink structure, Nevada Test Site: U.S. Geological Survey Report USGS-474-36, (Rev. 1) [NTS-217, Rev. 1], 24 p.

Howard, N. W., 1983, LLNL site characterization for containment of nuclear tests: Lawrence Livermore National Laboratory Report UCRL-53446, 33 p.

Humphreys, C. P., and Taylor, R. E., 1965, Streamflow in Lower Little Creek Basin affected by the Salmon event, Lamar County, Mississippi: U.S. Geological Survey Technical Letter Dribble-43, $14 \mathrm{p}$.

Hunter, R. B. (compiler), 1992, Status of the flora and fauna on the Nevada Test Site, 1988, Reynolds Electrical \& Engineering Co., Inc., Report DOE/NV/10630-29.

Hunter, R. B. (compiler), 1994a, Status of the flora and fauna on the Nevada Test Site, 19891991, Reynolds Electrical \& Engineering Co., Inc., Report DOE/NV/11432-57.

Hunter, R. B. (compiler), 1994b, Status of the flora and fauna on the Nevada Test Site, 1992, Reynolds Electrical \& Engineering Co., Inc., Report DOE/NV/1 1432-58.

Hunter, R. B. (compiler), 1994c, Status of the flora and fauna on the Nevada Test Site, 1993, Reynolds Electrical \& Engineering Co., Inc., Report DOE/NV/1 1432-162.

Hunter, R. B. (compiler), 1995, Status of the fiora and fauna on the Nevada Test Site, 1994, Reynolds Electrical \& Engineering Co., Inc., Report DOE/NV/11432-195.

Jenkins, E. C., 1973, Surface fracturing of the Carpetbag event, Yucca Flat, Nevada Test Site, Nevada: U.S. Geological Survey Report USGS-474-160 [NTS-233], 15 p.

Johnson, G. W., and Violet, C. E., 1958, Phenomenology of contained underground nuclear explosions: Lawrence Radiation Laboratory Report UCRL-5124, Rev. 1.

Jones, E. M., 1978, Collapse phenomena in NTS alluvium (U): Los Alamos National Laboratory Report J-90-78-20 (C-FRD).

Jorgensen, C. D., Allred, D. M., and Beck, D. E., 1963, Some effects of an underground nuclear detonation on biotic communities at the Nevada Test Site: Proceedings of the Utah Academy of Sciences, Arts, and Letters, v. 40, part 1, p. 49-61. 
Kao, C. S., Smith, D. K., and McKinnis, W. B., 1994, New observations of infiltration through fractured alluvium in Yucca Flat, Nevada Test Site: A preliminary field investigation: Lawrence Livermore National Laboratory Report UCRL-ID-116129, 41 p.

Kirkwood, J. B, 1970, Amchitka Bioenvironmental Program. Bioenvironmental safety studies, Amchitka Island, Alaska--Milrow D+2 months report: Battelle Memorial Institute, Columbus Laboratories, U.S. Atomic Energy Commission Report BMI-171-126, 44 p.

Kirkwood, J. B., and Fuller, R. G., 1972, Amchitka Bioenvironmental Program.

Bioenvironmental safety studies, Amchitka Island, Alaska--Cannikin D+2 months report: Battelle Memorial Institute, Columbus Laboratories, U.S. Atomic Energy Commission Report BMI-171-147, 62 p.

Koh, R. C. Y., and Rosencrantz, D., 1970, Ocean surface effects generated by a nearby underground explosion at the Amchitka Test: Tetra Tech Report TC-174-1 [NVO-289-6-1], 39 p.

Knox, J. B., Rawson, D. E., and Korver, J. A., 1965, Analysis of a groundwater anomaly created by an underground nuclear explosion: Journal of Geophysical Research, v. 70, no. 4, p. 823-835.

Krier, D. J., 1983, USGS PG-2 plotter-generated surface effects map: Responsibilities and transmittal of information; Los Alamos National Laboratory memorandum, Krier to House, $2 \mathrm{p}$.

Kunkle, T. D., 1994, An introduction to underground nuclear phenomenology - or what happens when the bomb goes off: Los Alamos National Laboratory informal document, $14 \mathrm{p}$.

Laczniak, R. J., Cole, J. C., Sawyer, D. A., and Trudeau, D. A., 1996, Summary of hydrologic controls on ground-water flow at the Nevada Test Site, Nye County, Nevada: U.S. Geological Survey Water-Resources Investigations Report 96-4109, 59 p.

Maldonado, F., 1977a, Composite postshot fracture map of Pahute Mesa, Nevada Test Site, June 1973 through March 1976: U.S. Geological Survey Report USGS-474-243 [Special Studies-93], 8 p.

Maldonado, F., 1977b, Explosion-induced fractures of selected announced underground nuclear tests, Yucca Flat, Nevada Test Site, Nevada, January through December 1975: U.S. Geological Survey Report USGS-474-235 [NTS-239], 25 p.

McKeown, F. A., and Dickey, D. D., 1960, Some relations between geology and effects of underground nuclear explosions at the Nevada Test Site, Nye County, Nevada, in Geological Survey Research 1960: U.S. Geological Survey Professional Paper 400-B, p. B415-B418. 
McKeown, F. A., Dickey, D. D., and Ellis, W. L., 1967, Maps and classification of explosioninduced fractures in Yucca Flat, Nevada Test Site: U.S. Geological Survey Technical Letter NTS-195, Supp. 1 (C-FRD).

McKeown, F. A., Young, R. A., Williams, W. P., and Brethauer, G. E., 1967, Geologic effects of the Long Shot explosion, Amchitka Island, Alaska: U.S. Geological Survey Report USGS-474-245, 73 p. [Long Shot-3]

McKeown, F. A., and Dickey, D. D., 1967, Map of explosion-produced fractures in Yucca Valley, Nevada Test Site: U.S. Geological Survey Technical Letter NTS-195.

McKeown, F. A., Dickey, D. D., and Ellis, W. L., 1968, Preliminary Report on the geologic effects of the Faultless Event: U.S. Geological Survey Report USGS-474-65 [Central Nevada-16], 20 p.

McKinnis, W. B., and Kao, C. S., 1993, Potential for infiltration through fractured alluvium in Yucca Flat of the Nevada Test Site: Preliminary Field Investigation, Unpublished Lawrence Livermore National Laboratory Report (Draft).

Merritt, M. L., 1970, Physical and biological effects, Milrow event: U.S. Atomic Energy Commission Report NVO-79, 113 p.

Merritt, M. L., 1973, Physical and biological effects, Cannikin: U.S. Atomic Energy Commission Report NVO-123, 104 p.

Merritt, M. L., 1973, Pressures in water on and near Amchitka Island, Milrow and Cannikin: Sandia Laboratories Report SC-RR-72 0547, 91 p.

Miller, C. H., and Miller, D. R., 1977, Orientation of explosion-induced surface fractures compared with preexplosion fractures and in situ stress measurements: Bulletin of the Association of Engineering Geologists, v. 14, no. 1, p. 27-37.

Morris, R. H., Gard, L. M., Jr., and Snyder, R. P., 1972, Visible geological effects of the CANNIKIN event: Bulletin of the Seismological Society of America, v. 62, no. 6, p. 1519-1526.

Morris, R. H., 1973, Topographic and isobase maps of the Cannikin sink, Amchitka Island, Alaska: U.S. Geological Survey Report USGS-474-125 [Amchitka-36], 8 p.

Newcombe, C. L., 1964, A theoretical analysis of available data on effects of shock waves on organisms that may serve as biological indicators of underground nuclear detonations: U.S. Naval Radiological Defense Laboratory Technical Report. 
Nordyke, M. D., 1964, Cratering experience with chemical and nuclear explosives, in Proceedings of the Third Plowshare Symposium--Engineering with Nuclear Explosives: U.S. Atomic Energy Commission Report TID-7695, p. 51-73.

Nordyke, M. D., 1975, A review of Soviet data on the peaceful uses of nuclear explosions: Lawrence Livermore Laboratory Report UCRL-76484, $47 \mathrm{p}$.

O'Farrell, T. P., and Emery, L. A., 1976, Ecology of the Nevada Test Site: A narrative summary and annotated bibliography; U.S. Energy Research and Development Administration Report NVO-167, $249 \mathrm{p}$.

Orkild, P. P., 1981, Geology of the Nevada Test Site, in Hudson, B. C., Jones, E. M., Keller, C. E., and Smith, C. W., eds., Proceedings of the Monterey Containment Symposium: Los Alamos National Laboratory Report LA-9211-C, vol. 1, p. 323-338.

Pickles, W. L., Shines, J. E., Hawley, D. L., Pelan, M. D., and Brewster, S. B., Jr., 1994, Lowaltitude overhead imagery acquisition pre- and post-NPE, in Denny, M. D., and Stull, S. P., eds., Proceedings of the Symposium on the Non-Proliferation Experiment (NPE): Results and Implications for Test Ban Treaties: Lawrence Livermore National Laboratory Report CONF-9404100, p. 8-63 to 8-70.

Piper, A. M., and Stead, F. W., 1965, Potential applications of nuclear explosives in the development and management of water resources--Principles: U.S. Geological Survey Open-File Report TEI-857, 128 p.

Quiring, R. F., 1965, Annual precipitation amount as a function of elevation in Nevada south of 38 $1 / 2$ degrees latitude: Weather Bureau Research Station, Las Vegas, NV, 14 p.

Quiring, R. F., 1968, Climatological data, Nevada Test Site and Nuclear Rocket Development Station: ESSA Technical Memorandum ARL-7, Environmental Sciences Service Administration, U.S. Department of Commerce, Las Vegas, NV, 177 p.

Rawson, D. E., and Borg, I. Y., 1970, Results of postshot exploration of the Greeley event: Lawrence Livermore National Laboratory Report UCRL-50979.

Rayburn, C. J., 1989, Crack at U-7bz reserve pit: Fenix \& Scisson Memorandum GEO-0705, Rayburn to Krier, 1 p.

Reed, W. E., 1970, Transport of water away from a buried heat source -- with special reference to hydrologic phenomena observed at Aardvark nuclear detonation: Journal of Geophysical Research, v. 75, p. 415-430.

Rodean, H. C., 1970, Explosion-produced ground motion: Technical summary with respect to seismic hazards, in Proceedings - Symposium on Engineering with Nuclear Explosives: American Nuclear Society and U.S. Atomic Energy Commission Report CONF-700101, vol. 2 [UCRL-71898], p. 1024-1050. 
Seymour, A. H., and Nakatani, R. A., 1967, Final Report--Long Shot bioenvironmental safety program: Univ. of Washington, U.S. Atomic Energy Commission Report RL-1385-1 [TID-24291], p. 49.

Shacklette, H. T., 1966a, The use of tundra vegetation in the detection of underground nuclear explosions: The report of the botanist on the VELA On-Site Inspection Amchitka Island Exercise, Nov. 20 - Dec. 10, 1965, 82 p. (C-FRD).

Shacklette, H. T., 1966b, The use of tundra vegetation in the detection of underground nuclear explosions: A report of a follow-up study made of the Project BRECCIA Amchitka Island VELA On-Site Inspection Exercise, August 9 - 23, 1966, 48 p. (C-FRD).

Shacklette, H. T., 1967, The use of tundra vegetation in the detection of underground nuclear explosions: A report of a second follow-up study made of the Project BRECCIA Amchitka Island VELA On-Site Inspection Exercise, June 5 -19, 1967, 36 p. (C-FRD).

Shacklette, H. T., Erdman, J. A., and Keith, J. R., 1970, Botanical techniques for on-site inspections of suspected underground nuclear explosions: U.S. Geological Survey Technical Letter, 194 p.

Short, N. M., 1964, Nuclear explosion craters, astroblemes, and cryptoexplosion structures: Lawrence Radiation Laboratory Report UCRL-7787, 75 p.

Shields, L. M., and Wells, P. V., 1962, Effects of nuclear testing on desert vegetation: Science, v. 135, p. 38-40.

Sinnock, S., 1982, Geology of the Nevada Test Site and nearby areas, southern Nevada: Sandia National Laboratory Report SAND82-2207, 57 p.

Snyder, R. P., 1971, Composite postshot fracture map of Pahute Mesa, Nevada Test Site: U.S. Geological Survey report USGS-474-100 [Special Studies-86], 13 p.

Snyder, R. P., 1975, Explosion-induced fractures of selected announced underground nuclear tests, Yucca Flat, Nevada Test Site, Nevada, January through December 1973: U.S. Geological Survey Report USGS-474-204 [NTS-255], 20 p.

Snyder, R. P., 1976, Explosion-induced fractures of selected announced underground nuclear tests, Yucca Flat, Nevada Test Site, Nevada, January through December 1974: U.S. Geological Survey Report USGS-474-209 [NTS-258], 25 p.

Snyder, R. P., and Rogers, Susan, 1972, Explosion-induced surface fractures of selected announced underground nuclear tests, Yucca Flat, Nevada Test Site, October 1969 through December 1970: U.S. Geological Survey Report USGS-474-133 [NTS-231], $53 \mathrm{p}$. 
Steele, S. G., and Snyder, R. P., 1972, Explosion-induced fractures of selected announced underground nuclear tests, Yucca Flat, Nevada Test Site, January 1971 through December 1971: U.S. Geological Survey Report USGS-474-155, 27 p. [NTS-237]

Steele, S. G., and Snyder, R. P., 1973, Explosion-induced fractures of selected announced underground nuclear tests, Yucca Flat, Nevada Test Site, Nevada, January through December 1972: U.S. Geological Survey Report USGS-474-176, 34 p. [NTS-245]

Stewart, J. H., 1980, Geology of Nevada: Nevada Bureau of Mines and Geology Special Publication 4, $136 \mathrm{p}$.

Swenson, F. A., 1959, Ground-water phenomena associated with the Hebgen Lake earthquake: U.S. Geological Survey Professional Paper 435-N, p. 159-165.

Swift, L. M., 1963, Intermediate range earth motion measurements - Project Gnome Final Report: U.S. Atomic Energy Commission Report PNE-111F, 74 p.

Taylor, R. E., 1966, Final investigation of water-well complaints related to Salmon event in Tatum Salt Dome Area, Lamar County, Mississippi: U.S. Geological Survey Technical Letter USGS-474-116, Supplement 1, 28 p. [Dribble-46].

Taylor, R. E., and Oakley, W. T., 1971, Water-well investigations before and after the Sterling event in Tatum Salt Dome, Lamar County, Mississippi: U.S. Geological Survey Report USGS-474-121, 10 p. [Dribble-55].

Thordarson, W., 1985, Hydrogeologic monitoring at the Faultless site, Nye County, Nevada: U.S. Geological Survey Open-File Report 84-580, 37 p.

Tueller, P. T., Bruner, A. D., and Davis, J. B., 1972, Ecology of Hot Creek Valley -- vegetation and soil response to underground detonation: U.S. Atomic Energy Commission Report NVO-409-1, $131 \mathrm{p}$.

Tueller, P. T., and Bruner, A. D., 1973, Immediate non-radiation effects on natural vegetation in the vicinity of Project Almendro: U.S. Atomic Energy Commission Preliminary Report, $13 \mathrm{p}$.

Tueller, P. T., Bruner, A. D., Everett, P., and Davis, J. B., 1974, The ecology of Hot Creek Valley, Nevada, and nonradiation effects of an underground nuclear detonation: U.S. Atomic Energy Commission Report NVO-409-2, 55 p.

Twenhofel, W. S., App, F. N., Duff, R. E., Keller, C. E., Morrison, F. A., and Hague, R. S., 1983, Final Data Needs Subcommittee Report to the Containment Evaluation Panel: unpubl. Containment Evaluation Panel report, $8 \mathrm{p}$. 
URS/John A. Blume \& Associates, Engineers, 1993, Seismic Safety Program: Ground motion and structural response: U.S. Department of Energy Report JAB-10733-2, 288 p.

USGS (see U.S. Geological Survey).

U.S. Atomic Energy Commission, 1967, Study related to reports of damage from the Salmon event--Project Dribble: U.S. Atomic Energy Commission Nevada Operations Office Report NVO-22, Rev. 1, 64 p.

U.S. Atomic Energy Commission, 1971, Project Gasbuggy managers report: U.S. Atomic Energy Commission Report NVO-37, 164 p.

U.S. Atomic Energy Commission, 1971, Seismology, aftershocks, and related phenomena associated with underground nuclear explosions - A bibliography of selected papers with abstracts: U.S. Atomic Energy Commission Nevada Operations Office Report NVO-87, $36 \mathrm{p}$.

U.S. Congress, 1989, The containment of underground nuclear explosions: Office of Technology Assessment Report OTA-ISC-414, 80 p.

U.S. Department of Energy, 1994, United States Nuclear Tests, July 1945 through September 1992, DOE/NV-209 (Rev. 14) (Available from U.S. Department of Commerce, National Technical Information Service, Springfield, Virginia, 22161).

U.S. Department of Energy, 1996, Nevada Test Site Final Environmental Impact Statement: U.S. Department of Energy Report DOE/EIS 0243, Vol. 1, p. 4-2.

U.S. Geological Survey, 1970, Geologic and hydrologic effects of the Milrow event, Amchitka Island, Aleutian Islands, Alaska: U.S. Geological Survey Report USGS-474-71, 72 p. [Amchitka-20].

U.S. Geological Survey, 1971, Geologic and hydrologic effects of the Handley event, Pahute Mesa, Nevada Test Site: U.S. Geological Survey Report USGS-474-95, 67 p. [Special Studies-83].

U.S. Geological Survey, 1972, Geologic and hydrologic effects of the Cannikin underground nuclear explosion, Amchitka Island, Aleutian Islands, Alaska: U.S. Geological Survey Report USGS-474-148, 83 p. [Amchitka-33].

U.S. Geological Survey, 1974, Bathymetry of Cannikin Lake, Amchitka Island, Aleutian Islands, Alaska: U.S. Geological Survey Report USGS-474-203, 24 p. 
Van de Werken, M. G., 1983, The PG-2 photogrammetric plotter--a rapid and accurate means of mapping surface effects produced by subsurface nuclear testing at the Nevada Test Site, Nevada, in Olsen, C. W., compiler, Proceedings of the Second Symposium on Containment of Underground Nuclear Explosions: Lawrence Livermore National Laboratory Report CONF-830882, v. 1, p. 393-410.

Videon, F. F., 1965, Crater Measurements, Final Report - Project Sulky: U.S. Army Corps of Engineers Report PNE-713F, $37 \mathrm{p}$.

Whicker, F. W., Alldredge, A. W., and Hanson, W. C., 1973, Project Rio Blanco--Prompt ecological effects resulting from ground motion: CER Geonuclear Corporation Report PNE-RB-47, $64 \mathrm{p}$.

Whicker, F. W., 1975, Project Rio Blanco--Investigation for possible delayed seismic effects on vegetation: CER Geonuclear Corporation Report PNE-RB-68, 7 p.

Williams, V. S., Garcia, M. N., and Covington, H. R., 1991, Digital maps of surface effects from nuclear explosions at the Nevada Test Site, in Olsen, C. W., and Price, M. E., eds., Proceedings of the Sixth Symposium on Containment of Nuclear Explosions: Lawrence Livermore National Laboratory Report CONF-9109114, vol. 2, p 252-261.

Winograd, I. J., and Thordarson, W., 1975, Hydrogeologic and hydrochemical framework, southcentral Great Basin, Nevada-California, with special reference to the Nevada Test Site: U.S. Geological Survey Professional Paper 712-C, p. C1-C26.

Wright, R. A., 1971a, Amchitka Bioenvironmental Program--Effects of underwater overpressures on sea otters and other aquatic animals--Final Progress Report, July 1, 1967 to June 30, 1969: Battelle Columbus Laboratories Report BMI-171-130, 26 p.

Wright, R. A., 1971b, Amchitka Bioenvironmental Program--Final Progress Report on sea otter studies during Milrow, July 1, 1969 to June 30, 1970: Battelle Columbus Laboratories Report BMI-171-136. 
This page intentionally left blank. 


\section{APPENDICES}


This page intentionally left blank. 


\section{APPENDIX A}

\section{GLOSSARY}

This glossary contains terms commonly used in the description and interpretation of surface effects of underground nuclear tests. These definitions reflect the context of their application and historical usage within the underground testing community, which may or may not be the same as in other disciplines. Numerous sources were consulted to compile this glossary, including the following:

U.S. Congress, 1989

Garcia, Drellack, and McKinnis, 1989 (Draft)

ERC, 1974

Block chatter. Small-scale movement of blocks of near-surface rock (defined by pre-existing joint systems) in response to explosion-induced stresses. The results of these movements may be mosaics of cracks in brittle surface materials (thin alluvial cover, pads, roads) or dust trails in snow that match the underlying joint patterns. The term is often used to describe features that appear to be caused by this mechanism without real knowledge of the operating mechanism.

Cavity. The approximately spherical void created by the vaporization, melting, and compaction of earth materials surrounding the point of detonation.

Chimney. A roughly cylindrical region of disoriented rock and rubble formed after the collapse of the explosion cavity, when the overlying material (overburden) fails and falls into the void.

Collapse (surface and subsurface). Sudden failure of earth materials as a result of loss of strength and/or cohesion.

Collapse sink. Topographic depression caused by the sudden failure of surface materials above a chimney. Genetically distinct from a crater in that there is no throw-out or vaporization of surface materials (cf retarc, crater). 
Concentric crack. Crack or parting of the ground surface in a circular orientation around the surface ground zero of an underground explosion (cf. radial crack).

Crack. Break or parting of the ground surface formed by explosion-induced mechanical failure. May be produced directly, through stress-wave effects such as spallation and spall closure, or indirectly, as a result of fault movement or the formation of a collapse sink.

Crater. Topographic depression caused by an explosion conducted in scaled proximity to ground level, that results in throw-out and/or vaporization of earth near the ground surface (cf. collapse sink, retarc).

Differential compaction. A phenomenon thought to occur when vibrations from an underground explosion cause unequal reductions in volume of a compactable material such as alluvium. The structure (faults, buried scarps, etc.), stratigraphy (thickness, layering, extent), and lithology (composition) of the overburden may vary dramatically within the region influenced by an underground explosion. These variations may result in unequal volume reductions within the overburden, sometimes causing offset at the surface along the boundaries (usually fault or buried scarp) that define them.

Disturbed ground. One or more subtle features that can indicate the passage of ground motion. These features include fluffed ground, collapsed animal burrows, overturned rocks, and turf disruptions.

Depth of burial (DOB). The vertical distance below the ground surface at which an explosive device is detonated.

Fault. A fracture that is vertically extensive (below the ground surface) along which displacement has occurred (i.e., blocks on either side of the fault plane have moved relative to each other).

Fluffed ground. Surface material that has a soft, loose consistency, as if it has been tossed vertically a short distance and landed in about the same location. Recognition may rely on familiarity with appearance of materials before the passage of ground shock. 
Fracture. A crack or break in rock, including both faults and joints. In the context of surface effects, a crack that has a limited vertical extent (below the ground surface) can be defined as a fracture.

Hairline crack. Short surface crack with a very small aperture (less than about $3 \mathrm{~mm}$ [0.25 in]) that forms as a result of the passage of ground shock from an underground explosion. Hairline cracks typically form on prepared surfaces, though they can sometimes be found on natural surfaces.

Joint. A natural fracture along which there has been no permanent relative movement of the adjacent rock blocks. Joints can form as a result of such phenomena as local and/or regional tectonic stresses or contraction during cooling (volcanic rocks).

Landslide. Large-scale mass movement of talus or debris down a steep slope.

Phenomenology. Study of the assorted phenomena associated with a nuclear test, including shock effects, stresses, seismic effects, spall, cavity and chimney formation, etc.

Prepared surface. Ground material that is unnaturally compacted, such as on a drill pad or road.

Pressure ridge. Raised, narrow surface undulation or "buckled" area; typically straight to slightly curved or locally sinuous.

Radial crack. Surface fractures oriented in a "spoke-like" pattern around the surface ground zero.

Rarefaction wave. Pressure wave that has been reflected off a free surface and is now traveling in the opposite direction as a tensional wave.

Reactivated crack. Crack from an older test that is reopened or otherwise altered.

Retarc: See rubble mound.

Revegetated crack. Surface crack from an old explosion that has since served as a location for preferential growth of plants. 
Rock fall. Mass movement of loose cobbles or boulders away from their original location.

Rock spall. Movement, with an upward and/or outward heaving, of slabs of rock from a cliff or other free surface. (cf. spall).

Rubble chimney. See chimney.

Rubble mound. A pile of broken rock which is the surface expression of a column of rubble produced by an explosion buried too deeply to form a crater and not deeply enough to form a collapse sink. Also called "retarc" ("crater" spelled backward).

Scaled depth of burial (SDOB). The depth of burial of an explosive device multiplied by a factor related to the device yield. Consideration of SDOBs permits comparison of tests of different yields and DOBs for containment evaluation purposes.

Slapdown. See spall closure.

Slump. The result of sliding down-slope of a mass of material. Similar to a landslide, but typified by a more fluid and coherent manner of mass movement.

Spall. Phenomenon during which stress waves generated by an underground explosion are reflected downward, with a $180^{\circ}$ reversal in phase, from the earth's surface as rarefaction or tensional waves. Where the sum of the energies of the remaining ascending waves, the overburden stress, and the tensile strength of the rock are less than the energy of the descending waves, layers of earth can separate along naturally occurring planes of weakness.

Spall closure. The very rapid settling of layers of earth loosened by the spall phenomenon. Also "slapdown."

Spall region. The three-dimensional zone of material affected by spall.

Surface effects. The disruptive aftermath resulting from an underground explosion, as expressed at the earth's surface. Includes geologic/hydrologic, ecological, and cultural-feature effects. Radiological effects (if any) at the surface typically are not considered surface effects. 
Surface Ground Zero (SGZ). That point on the surface directly above Ground Zero (GZ) or the Working Point (WP) in an underground nuclear test.

Working Point (WP). A reference to the location of a nuclear device in an underground nuclear test. 
This page intentionally left blank. 


\section{APPENDIX B}

\section{OVERVIEW OF THE NEVADA TEST SITE}

The following paragraphs present a brief description of the NTS, highlighting some of the attributes that are thought to be important to the recognition, documentation, and understanding of surface effects.

\section{B-1.0 LOCATION}

The Nevada Test Site is located in south-central Nevada, approximately $105 \mathrm{~km}$ (65 miles) northwest of Las Vegas (Figure B-1). The NTS occupies an area of approximately $3496 \mathrm{~km}^{2}$ (1350 square miles), of which an area of about $1554 \mathrm{~km}^{2}$ (600 square miles) was utilized for nuclear testing. The NTS is divided into 26 areas that encompass a variety of geologic and physiographic settings.

\section{B-2.0 CLIMATE}

The NTS is located in the high desert, with precipitation rates averaging about $9 \mathrm{~cm} / \mathrm{yr}$ in the lower elevations to approximately $25 \mathrm{~cm} / \mathrm{yr}$ on Pahute Mesa (Quiring, 1965). Temperatures vary with elevation, ranging from extremes of about $43^{\circ}$ to $-26^{\circ} \mathrm{C}\left(110^{\circ}\right.$ to $\left.-14^{\circ} \mathrm{F}\right)$. Monthly average temperatures range from $7^{\circ} \mathrm{C}\left(44^{\circ} \mathrm{F}\right)$ in January to $32^{\circ} \mathrm{C}\left(90^{\circ} \mathrm{F}\right)$ in July (Quiring, 1968).

Evaporation rates are high, and except for a few small springs, there is no permanent surface water on the NTS.

Precipitation events at the NTS are usually sporadic, typically falling as small amounts of rain or snow during isolated, short-duration winter and summer storms. These storms usually do not produce enough precipitation to cause runoff into the basins, and any moisture that does accumulate usually is absorbed quickly into the alluvium. 


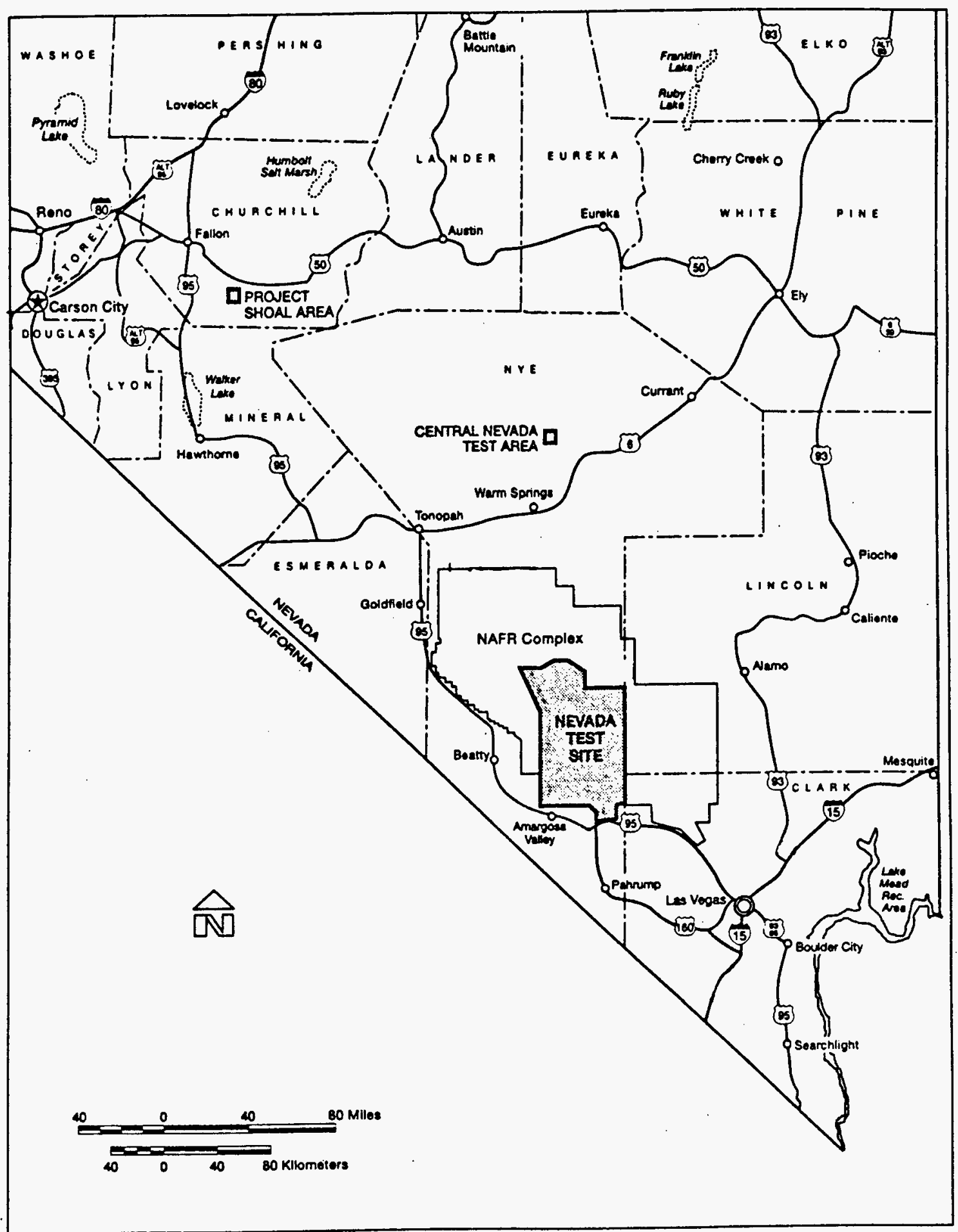

Figure B-1. Location of the Nevada Test Site (adapted from DOE, 1996). 


\section{B-3.0 VEGETATION}

Located in a zone of transition, the NTS has a diverse flora that includes elements of both the Mohave and Great Basin deserts. Mohave-type floral associations dominated by creosote and

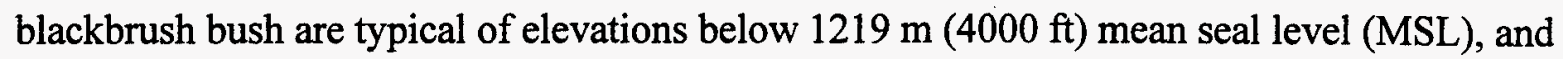
Great Basin-type assemblages associated with sagebrush are common at elevations above 1524 $\mathrm{m}(5000 \mathrm{ft}) \mathrm{MSL}$. Higher elevations (above $1829 \mathrm{~m}$ [6000 ft] MSL) are dominated by a mix of juniper trees, pinyon pines, and sagebrush. Ground cover is provided primarily by an assortment of forbs and grasses, whose individuals dominate according to annual precipitation, temperature, and soil type (O'Farrel and Emery, 1976).

\section{B-4.0 TOPOGRAPHY}

The NTS is located in the southern part of the Great Basin section of the Basin and Range Physiographic Province (Stewart, 1980). The topography of most of the NTS is typical of the Basin and Range province, with long, linear mountain ranges separated by closed, down-dropped valleys. These features are modified locally by the Las Vegas Shear Zone in the southern part of the NTS, and by resurgent calderas in the northwestern portions of the site (i.e., Timber Mountain and Pahute Mesa). Ground elevation at the NTS ranges from about 850 to $2340 \mathrm{~m}$ (2789 to $7677 \mathrm{ft}$ ) MSL, and topographic features include extremely flat playa lakebeds, gently sloping alluvium-filled valleys, relatively rugged hogbacks and ridges, and several flat-topped buttes and mesas. These features are dissected locally by drainage ways, such as steep-sided canyons and arroyos.

It should be mentioned that the topography of certain areas of the NTS has been altered because of human activity, specifically underground nuclear testing. The most conspicuous effect of underground testing has been the formation of numerous craters and collapse sinks. These features are described in detail in Section 3.0 of this report.

\section{B-5.0 GEOLOGY}

The geology of the NTS is complex, reflecting a number of diverse depositional, erosional, and tectonic episodes which affected the area. The following synopsis is offered as a brief summary 
of the geologic setting of the NTS, and is based on several references, including Ekren (1968), Orkild (1981), Sinnock (1982), Frizzel and Shulters (1990), and Drellack (1994).

The surface geology of the NTS is dominated by three major rock types: (1) uppermost Precambrian- and Paleozoic-age sedimentary and metasedimentary rocks, (2) Tertiary-age volcanic rocks, and (3) Tertiary-age to recent alluvial deposits. In addition, there are several small exposures of Mesozoic-age granitic intrusives and Cenozoic-age basalt-flow deposits (Figure B-2).

Upper Precambrian- and Paleozoic-age rocks at the NTS can be grouped into several dominant lithostratigraphic units: (1) upper Precambrian through lower Cambrian clastic rocks (chiefly quartzites), (2) mid-Cambrian through mid-Devonian carbonate rocks, (3) upper-Devonian and Mississippian clastic rocks, and (4) Pennsylvanian and Permian carbonate rocks. These units represent a nearly continuous 40,000 -ft thick section of intensely folded and faulted rock. Units within this section occupy approximately 20 percent of the surface area of the NTS, and form many of the ridges and hogbacks in the area.

Tertiary-age volcanic rocks at the NTS were deposited during eruptions from volcanic centers associated with the southwestern Nevada volcanic field (SWNVF). Volcanic rocks of the SWNVF were deposited between approximately 15.5 and 7.5 million years ago, and are composed mostly of silicic ash-fall and ash-flow deposits. The SWNVF includes at least six major caldera complexes within or near the NTS boundaries. Eruptions from these sources were voluminous, depositing a composite section of approximately $30,000 \mathrm{ft}$ of volcanics in the area. Deposits from these eruptions blanketed the post-Mesozoic erosional terrain, which at that time was being down-dropped due to crustal extension. Tertiary-age volcanic rocks form several prominent mesas and ridges in the area, and occupy approximately 40 percent of the NTS surface.

The late Tertiary of the NTS was a time of waning volcanism, with increased erosion and alluviation. Alluvial sediments were deposited primarily as valley fill via numerous, coalescing alluvial fans emanating from the surrounding highlands. Alluvium deposits consist chiefly of moderately consolidated to unconsolidated channel and slope wash detritus. In addition, playa lake deposits are present in several of the closed basins that occupy the NTS. Alluviation continues to the present, with deposits covering about 40 percent of the NTS surface. 


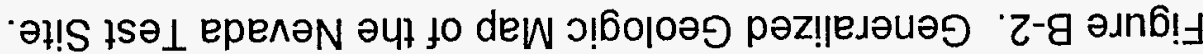

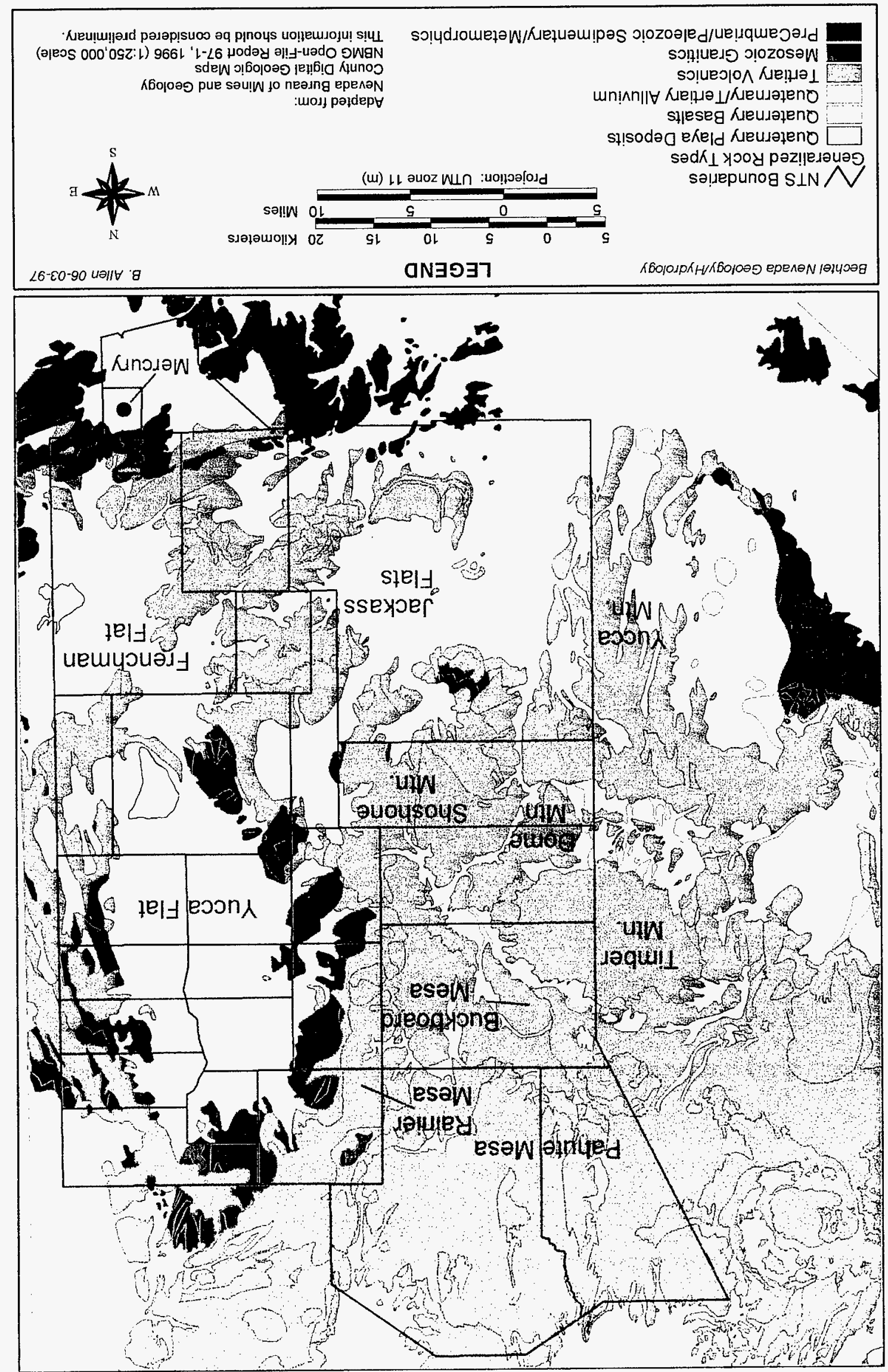


This page intentionally left blank. 
The area defined by the NTS is structurally complex, and its structural history is characterized tectonically by several major events: (1) Mesozoic compressional deformation, including regional thrust faults, folds, and wrench faults, (2) Cenozoic extensional deformation, including normal and strike-slip faults associated with development of the basin-and-range structural province, and (3) Tertiary volcanic structures (overlapping and juxtaposed collapsed calderas) associated with eruptions of the SWNVF.

\section{B-6.0 HYDROLOGY}

Like the geologic setting, the hydrologic framework of the NTS is complex; primarily because of the irregular extent, variable hydrologic characteristics, and structural complexity of rock units in the vicinity. Groundwater in the area is conveyed within several regional flow-system subbasins within the Death Valley flow system (Harril, et al, 1988; Laczniak, et al., 1996). Groundwater flow beneath the NTS and immediate vicinity is generally to the south-southwest, from recharge areas in central Nevada to areas of surface discharge in and around Amargosa Valley and Death Valley.

Groundwater elevation typically reflects the north-to-south gradient, ranging from about $1433 \mathrm{~m}$ (4700 ft) MSL in northern parts of the NTS, to about $716 \mathrm{~m}$ (2350 ft) MSL in the south. Groundwater elevation in the Pahute Mesa-Rainier Mesa area is relatively high, ranging from about 1433 to $1280 \mathrm{~m}$ ( 4700 to $4200 \mathrm{ft}$ ) MSL. The groundwater table in the Yucca Flat test area is generally much lower, approaching $716 \mathrm{~m}$ ( $2350 \mathrm{ft}) \mathrm{MSL}$ in central portions of the valley. Perched and semi-perched water is also present in several areas of the NTS.

As first categorized by Winograd and Thordarson (1975), no less than six major hydrogeologic units influence the flow of water both regionally and locally in the NTS vicinity. The definition of these units is generally based on the hydraulic properties, lithologic character, and stratigraphic position of the unit. The units typically recognized include: (1) the lower clastic confining unit, (2) the lower carbonate aquifer, (3) the upper clastic confining unit, (4) the tuff confining unit, (5) the welded tuff and lava flow aquifer, and (6) the valley-fill aquifer (adapted from Winograd and Thordarson, 1975; and Laczniak, et al, 1996). 
Several noteworthy investigations have examined various aspects of the hydrology of the NTS and surrounding area. These include studies by Blankennagel and Weir (1973), Winograd and Thordarson (1975), Harril, et al, (1988), Hale, et al, (1995), and Laczniak, et al., (1996). 


\section{APPENDIX C}

\section{PROCEDURES USED FOR THE DOCUMENTATION OF SURFACE EFFECTS AT THE NEVADA TEST SITE}

\section{C-1.0 INTRODUCTION}

\section{C-1.1 Purpose}

This section describes how geologic surface effects from underground nuclear tests were documented at the NTS, with emphasis on the field mapping and reporting processes. The authors intend this document to serve at least three purposes:

1. Document how post-shot surfaces effects mapping was conducted at the NTS prior to the moratorium in September 1992 (archival information). Also provide some of the rationale behind these procedures.

2. Provide information that could be useful for any future need to conduct surface effects mapping, should testing resume (test readiness).

3. Provide insights into possible application to related CTBT activities (e.g., on-site inspection).

This section is organized as a working procedure or instruction that was modified from formal DOE contractor field mapping procedures originally developed to ensure the proper documentation of surface effects mapping at the NTS. This section addresses some conditions that are probably unique to the NTS, however, most of the subjects discussed herein probably would be applicable to other locations as well.

The reader should understand that techniques other than those used successfully at the NTS are examined only superficially. Advances in technology (remote sensing, etc.) might replace some of the methods described herein. However, it has been found that remote methods alone (such as relying only on aerial photos) can result in missed and misidentified surface features. Although the NTS test areas present a favorable setting for remote methods (relatively flat terrain, sparse 
ground cover, and favorable weather conditions most of the time), experience has shown that geologists mapping in the field can provide the most reliable "ground truth" for remote techniques.

\section{C-1.2 Organizations Responsible for Surface Effects Mapping}

The surface effects of underground nuclear tests were studied and documented primarily by the USGS until approximately 1977 when the individual testing organizations assumed that responsibility. At that time the LANL and the DNA (now DSWA) delegated field mapping to the DOE contractor responsible for NTS geologic support. The LLNL utilized in-house personnel (occasionally assisted by DOE contractor geologists) to document surface effects from their tests.

The USGS has pursued photogrammetric mapping of surface effects for all LLNL- and LANLsponsored tests. In this process, surface effects recorded in the field are transferred from the original mapping medium (typically aerial photos) to a single scale-stable map format. In addition, features not recorded by the field geologists, such as cracks within the perimeter fence and the collapse crater size and shape, are transferred from post-shot aerial photos if available (Garcia, 1987, 1989; Garcia, et al., 1989). The USGS also compiled and maintained composite post-shot surface effects maps for Yucca Flat and Pahute Mesa, derived from the test-specific maps generated photogrammetrically (Covington, 1987).

The BN Geology/Hydrology Section (and its predecessors) has had continuous responsibility for weapons-related geologic mapping, including documentation of surface effects, at the NTS since 1977 (except for LLNL sites). The same cadre of geologists has been employed by successive DOE contractors starting with Fenix \& Scisson, continuing with RSN, and now with BN.

\section{C-2.0 FIELD MAPPING PROCEDURES}

This section describes field procedures used at the NTS since about 1977 for mapping and documentation of surface effects. 


\section{C-2.1 Pre-test Preparations}

Preparations for investigation and documentation of surface effects begin well before an underground test is conducted. The geologists who will be responsible for mapping the surface effects generally plan for this field mapping effort as described in this section. In addition, the testing organization may request the geologists' assistance in planning and deploying other types of surface studies, such as pre- versus post-test elevation comparisons. Examples of this type of study are presented in Section C-4.0.

\section{C-2.1.1 Field Geologic Mapping Team}

Typically, a lead geologist has direct responsibility for the supervision and quality of the mapping and documentation of surface effects. The team leader coordinates with the testing organizations' containment scientists and test operations directors, and maintains the continuity of the project. The team leader should ensure that the team has the information and materials needed for the project.

\section{C-2.1.2 Planning and Preparation}

Sufficient time should be allocated for planning and preparation prior to the test. The surface effects mapping team (also referred to herein as "field geologists") must be aware of basic test parameters, including design yield, DOB, test configuration (which could affect expected ground motion), expected spall radius, and the potential for surface collapse. Familiarity with local surface and subsurface geology and with previous surface effects from nearby tests is imperative. The necessary materials must be assembled and the team briefed in advance to allow rapid mobilization after the test (see Section C-7.0).

Geologic information that can influence surface effects may be obtained from the following sources, which should be consulted prior to mapping and during evaluation of mapping data:

1. USGS post-shot composite crack maps.

2. Crack maps for nearby tests (test-specific data may be more detailed and thus more useful than the larger composite map).

3. Geologic maps.

4. Test-specific geologic packages (especially standard geologic cross sections).

5. Geophysical data (seismic, magnetics, etc.). 


\section{C-2.1.3 Pre-test Reconnaissance}

The mapping team should make a pre-test reconnaissance trip to the site, primarily to note any surface effects in the area from previous tests. The team should also become familiar with the lay of the land, identify useful landmarks, and generally develop a working familiarity with the mapping media (i.e., aerial photos, topographic maps, geologic maps, etc.). If any survey markers are identified, the team should make an effort to find out their purpose, as well as their location coordinates, elevation, orientation, etc. This information often can be valuable for mapping purposes, especially in providing additional reference points.

\section{C-2.2 Post-test Field Mapping Considerations}

\section{C-2.2.1 Scheduling}

Mapping should be started as soon after the test as possible. The team leader must keep in touch with field operations personnel so that the mapping team can be mobilized as soon as access to the forward areas is authorized. Early mobilization allows the field geologists to map surface effects on roads and post-shot pads before the features are destroyed by vehicular traffic, rain, or wind. Because certain personnel may be allowed priority access to the diagnostic recording trailers before the immediate site is opened, some features may be obliterated by their activities. However, most large fractures usually are not completely destroyed or obscured.

\section{C-2.2.2 Scope of Mapping Effort}

Geologists map all surface effects produced by the underground nuclear explosion--within reason. The type, magnitude, and extent of surface effects can vary considerably, as one might expect. The full spectrum of surface effects has been documented at the NTS, ranging from no visible effects following low-yield or overburied tests, to extensive cracking over several square miles. The nature and extent of surface effects are dependent upon test parameters (yield, DOB), nature of the surficial material (sandy vs. hard and jointed), and subsurface structure. Thus, it is important to record all geologic observations and associations to aid later interpretations.

Descriptions of test-related surface features are provided in Sections 3.0 and C-2.3.

\section{C-2.2.3 Initial Visual Inspection}

The field team first makes a visual assessment of the area to begin planning the mapping task. The density and magnitude of cracking along any access roads, drill pads, and around the 
perimeter fence usually dictate the areal extent of the mapping effort. The density and extent of cracking also factor into mapping strategies. For example, the team must decide if it is appropriate, given the scale of the job, to map all hairline cracks (see Section C-2.3.4). Mapping may begin during this reconnaissance survey, but the inspection is generally for orientation purposes: the team must assess the density, extent, and type of surface effects, devise a work plan, and estimate time and manpower requirements to complete the job.

\section{C-2.2.4 Size of Mapping Area}

Often the extent of cracking is limited to the spall radius (c.f. "rock spall" in Appendix A). However, it is not uncommon for cracking to occur along the surface trace of subsurface structure beyond the spall radius. Consequently, test parameters and local geology factor heavily into determining the maximum area the field geologist must cover. In practice however, the field geologist will explore outward from SGZ until no more surface effects can be found, and then go a little farther to be sure the limit of surface effects has been reached. Persistent crack trends from nearby tests should be checked for reactivation or extension. The area of investigation for LANL and LLNL tests at the NTS is usually within the area covered by the standard pre-shot set of aerial photos $(9 \times 9$ inch prints at 1:4800 scale). For lower yield detonations, one photo may be sufficient to plot all the surface effects. However, geologists commonly examine or traverse beyond photo coverage in order to spot-check roads or areas with possible subsurface structure. Areas near or above subsurface structure are searched employing a straight-line or meandering "S-shaped" search pattern.

\section{C-2.3 Types of Features Mapped}

\section{C-2.3.1 Cracks}

Surface cracking can be categorized by geometry, location, or more subtle characteristics (Section 3.1.6). Crack patterns might be random or exhibit recognizable trends. Relatively close to SGZ, the dominant fractures tend to be radial to or concentric around the surface crater or SGZ. Cracks also might parallel subsurface structures such as a buried fault, or mimic joint patterns of a near-surface formation. Cracking is generally more extensive on prepared surfaces (access roads, drill pads, cable ways, etc.) than on undisturbed ground. Pre-existing cracks from nearby tests that might have been reactivated by the new test can sometimes be recognized by their rounded, eroded edges, or by the presence of linear patterns of vegetation. 


\section{C-2.3.2 Collapse Sinks}

The field team should make a general description of any surface collapse feature. Morphological characteristics recorded include: crater shape (circular or elliptical); symmetry about SGZ; depth; general shape of the sides, such as dish-shaped, stepped, "post-hole," etc. An estimate of its diameter(s) should also be recorded. The north-south and west-east axes through SGZ are

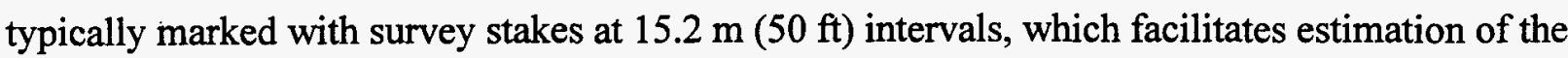
crater shape and size. Depending upon the terrain, it may be necessary to make such observations from a vantage point such as the bed or roof of a truck. Some of this information may (or may not) be obtained later from post-shot aerial photos. However, it is best to record all observations from the field whenever possible and not depend on future opportunities.

\section{C-2.3.3 Other Post-shot Surface Effects}

Other surface effects also convey important information and should be accurately depicted on the field map. These include, but are not limited to, pressure ridges, rock spall, fluffed ground, uprooted trees, collapsed animal burrows, etc. (see Section 3.1). Written descriptions or observations should be recorded in the field logbook and referenced to the map using an alphanumeric flagging scheme. The geologists may also record ground motion effects on cultural features, such as damage to facilities, upset power poles, or compaction of fill material. Typically, damage assessments of structures and equipment are conducted by other groups at the NTS and addressed in separate reports.

\section{C-2.3.4 Definition of Significant Features}

The exact definition of a mappable, significant feature is somewhat subjective. As mentioned earlier, the field geologist should try to map all surface effects. The significance of a feature may not be apparent until later, after all the field data have been plotted. It is important that adequate descriptions and observations be recorded in the field logbook. Wherever possible, the field geologist should differentiate between hairline cracks, large cracks, and cracks with vertical displacement. The latter two are nearly always considered to be significant. However, in the past, not all hairline cracks have been differentiated or labeled as such. Also, random hairline cracks may be omitted for larger detonations, whereas all observed cracks may be plotted for small tests. This inconsistency must be considered when attempting to interpret composite crack map data, and points out the need for consistent definitions of crack species and magnitude. 


\section{C-3.0 METHOD OF RECORDING SURFACE EFFECTS}

Descriptive field data, including observations and correlations, should be legibly recorded in field notebooks. Sketches and hand-drawn maps are commonly included, and photos of representative or unusual features might also be taken. Photo cue cards presenting date, a brief identifier, and a graphic scale should be included in each photo if possible (see Section C-9.2 for clearance requirements for photography at the NTS).

When documenting cracks, any measurable vertical displacement is recorded in centimeters and annotated on the map using the common bar-and-ball symbol for faults. Crack aperture and depth measurements are usually noted in the field logbook. It may be practical on larger detonations to represent general cracking trends rather than spend many hours trying to record each individual crack. Any general pattern formed by numerous, closely spaced cracks may be represented diagrammatically on the field map with just a few lines. Reactivated cracks can be remapped individually or collectively, then labeled with an " $R$ " to indicate reactivation.

Mapping onto recent (i.e., taken after the last dirt work was conducted and in the same season as the mapping) large-scale aerial photos has proven to be the most effective method for recording surface effects in the field. The ideal mapping base is a set of photos taken immediately after detonation and/or surface collapse. In the past, photos were taken within two days after detonation, however, they usually were not available for use until a couple of weeks later. Stereophotographic coverage is particularly helpful in areas with topographical relief. Typically, a nine-photo set at the scale of 1:4800 is taken of the area prior to each test conducted on Pahute Mesa or Yucca Flat. In instances where recent aerial photo coverage is found to be inadequate for surface-effects mapping, the following alternatives may be used, in order of preference:

1. Aerial photos from recent nearby tests.

2. "Extended coverage" photos for the NTS (sometimes flown for non-weapons testing purposes).

3. Topographical and/or USGS geologic maps.

4. Written descriptions of cracks with distance and bearing from recognized landmarks.

Symbols commonly used to indicate surface effects on maps and photos are listed in Table C-1. 
Table C-1

Symbols used to designate surface effects on maps and aerial photos.

\begin{tabular}{|c|c|}
\hline Map Symbol & Definition \\
\hline & Topographical edge of a collapse sink (or crater). \\
\hline - SGZ & Surface ground zero (SGZ) for the underground test. \\
\hline$\oplus U-7 \mathrm{ba}$ & Drill hole, with hole designation. \\
\hline & $\begin{array}{l}\text { Fracture or crack, large or small; may be radial to or } \\
\text { concentric around SGZ; may also be linear if related to } \\
\text { subsurface structure. }\end{array}$ \\
\hline & $\begin{array}{l}\text { Reactivated crack; renewed cracking along an older } \\
\text { crack scar. }\end{array}$ \\
\hline$-H$ & Hairline crack (aperture less than $3 \mathrm{~mm}$ ). \\
\hline$\sqrt{7}$ & $\begin{array}{l}\text { Fracture with some vertical displacement. Bar and ball } \\
\text { on down-thrown side; displacement in } \mathrm{cm} \text {. }\end{array}$ \\
\hline 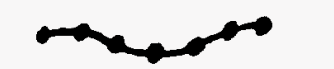 & Pressure ridge (old symbol was "P"). \\
\hline "BC" or "\# BC" & Block chatter. \\
\hline "A", "B", "C", etc. & Flag for a note regarding the immediate area or feature. \\
\hline "S" or "spall" & Rock spall along a free surface (topographic edge). \\
\hline$-\cdot-\cdot-$ & Perimeter and trailer park fence. \\
\hline
\end{tabular}




\section{C-4.0 SUPPORT OF OTHER INVESTIGATIONS}

Geologists familiar with a particular test may be required to assist in planning the deployment of monitoring equipment and/or execution of various experiments. For example, geologists may be asked to identify surface structural features for placement of cameras or other monitoring devices, or to aid in various pre-test surface investigations.

It is useful, particularly for tests with large SDOBs (i.e., not expected to collapse to the surface), to conduct pre- versus post-test geodetic surveys. The purpose of these measurements is to detect small changes in elevation that might result from slight subsidence or from doming. Typically, a pair of orthogonal survey lines, with one line at right angles to the local structural trend, is placed by surveyors so that the lines cross at the SGZ. The lines consist of survey monuments placed at appropriate intervals from SGZ. These monuments are typically closely spaced ( $7.6 \mathrm{~m}[25 \mathrm{ft}]$ intervals) near SGZ, and spaced farther ( $15.2 \mathrm{~m}[50 \mathrm{ft}]$ intervals) at some distance away from SGZ. Surveyors provide pre-test coordinates and elevations for the monuments, and then reoccupy the stations as soon as possible after the test to remeasure the monument positions. A similar set of survey lines may also be emplaced around or across the area of an expected collapse sink to determine subtle changes at the edges of the sink or nonsink-related elevation changes at some distance from it. The field geologist should be aware of these lines and carefully map any surface effects along or in the vicinity of these lines.

\section{C-5.0 SAFETY CONCERNS}

Reentry/recovery operations may present hazards in the vicinity of SGZ. Upon arriving at the site, the field geologists should always check in with the field operations personnel and the Radiological Control mobile command station. Field operations personnel may request information on the team size and the general mapping plan. In addition, field activities in rugged and/or remote localities require a heightened awareness of personnel safety.

\section{C-5.1 Weather and Natural Hazards}

Weather conditions must be factored into the daily work plan. At the NTS, temperatures can be extreme and variable depending upon season and elevation. Test areas in higher elevations 
(Rainier and Pahute Mesas) can be quite cold in the winter (especially with windchill), and snow is not uncommon. Field geologists also must be prepared for sun, heat, and the potential for dehydration while mapping effects of tests conducted during the summer at lower elevations, where temperatures over $100^{\circ} \mathrm{F}$ are not uncommon. The canyons and mesas of Areas 12,19 , and 20 present hazards of rockfall and loose soil, perhaps loosened further by ground motion from the test. Additional hazards are presented by some indigenous wildlife (e.g., rattlesnakes, scorpions, coyotes, mountain lions, etc.). Fortunately, encounters with these creatures are rare.

\section{C-5.2 Radiation Exposure}

Radiation leaks were uncommon during the era of modern containment practices in the United States: only four minor gas leaks were detected in the last 21 years of testing at the NTS. A standard array of downhole and surface radiation detectors would provide an early, remote indication of escaping radioactive gases. Consequently, radiation exposure from a containment failure was not considered a credible threat to the field geologist.

Post-shot drill-backs could potentially provide a leak path to the surface for radioactive cavity gases. However, a combination of drill techniques (forcing lost circulation) and engineered controls (blowout preventors at the casing head) provide effective control. Redundant radiation detectors with audio alarms are positioned at the casing head and on the drill rig floor to serve as a warning system for leaking gases associated with post-shot drilling activities. In most cases, field mapping activities are completed by the time the post-shot drilling penetrates the cavity. Nevertheless, all personnel in the area must be aware of what the radiation alarm sounds like, be conscious of local wind direction, and know what to do in case evacuation of the area is required.

\section{C-5.3 Drilling and Construction Equipment}

Immediately following a test, a flurry of activity can be expected; road graders usually are dispatched to repair damaged access roads, the post-shot rig and attendant equipment are being mobilized, and vehicular traffic is concentrated in the trailer park area. Although working around this large noisy machinery is inherently dangerous, these are the areas which the field geologist must quickly map before surface effects are obliterated. Under such circumstances the field team must be ever vigilant and cautious. 


\section{C-5.4 Surface Collapse}

Cavity collapse and formation of a surface sink occur within 12 hours after most underground nuclear tests in Yucca Flat. However, delayed collapses of several days or additional collapse of an existing crater is not unprecedented. On Pahute Mesa and Rainier Mesa, however, collapse to the surface is rare. Prior to test day, the area of potential collapse (plus a safety buffer zone) is roped off to prevent access. The field geologists do not enter the area encompassed by this perimeter fence. Larger features inside this restricted area may be mapped from an outside vantage point, or they may be observed on post-shot aerial photos.

In the rare instance when it might be deemed important to enter the area inside the perimeter fence of an uncollapsed site, special safety precautions must be taken. In the past, this has included setting up a seismic monitoring system nearby to detect renewed subsurface activity or upward stoping of a collapsing void. Radio contact should be maintained between the field team and the seismic monitoring station.

The diagnostic cables leading from the strongback at SGZ to the instrument trailers pose another potentially dangerous area because intermittent surface or subsurface collapse can unexpectedly yank the slack from the cables. Although the main cableway is typically roped off and closed to personnel, geologists should beware of potential cable movement when mapping around the instrument trailers.

\section{C-6.0 AREA ACCESS}

Safety and security concerns usually govern when the mapping team is allowed to enter the test area to document surface effects. The following paragraphs describe standard procedures followed at the NTS.

\section{C-6.1 Forward Areas}

At the NTS, the forward areas are "closed" on the day before the test for security and safety purposes (there is limited access to approved test-related personnel). After the test, a limited- 
access area defined by fencing and guards is maintained around the diagnostic trailer park until the test data are recovered. Following the successful execution of the test, the forward areas are reopened to the general NTS worker at the discretion of the test director. Generally, the forward areas are opened soon after subsurface collapse or the formation of a surface collapse sink. If a surface sink does not form, and subsurface collapse is believed not to be complete, the forward areas remained closed for at least 24 hours.

\section{C-6.2 Control Point}

The organization sponsoring the test may request that a field geologist be present at the Control Point (CP) to observe an underground nuclear test. Typically, this geologist was also responsible for the geologic characterization of the emplacement site. The presence of the field geologist at $\mathrm{CP}$ on shot day is beneficial for several reasons:

1. The field geologist can view in real time the imagery from the orbiting cloudtracking helicopter and the stationary ground-based cameras. The geologist can note any phenomena, such as aberrant ground motion, dust cloud sources, or visible fracturing sequences, which would be used to direct later ground-based inspections.

2. Site-specific geologic expertise is immediately available to the containment scientist, who in turn provides technical advice as needed to the test director.

3. The field geologist at CP (typically the field team leader) can notify the other team members when to mobilize and can provide test performance information (initial yield estimate vs. design), as well as information about ground motions and collapse characteristics.

\section{C-7.0 LOGISTICS}

The various equipment and materials used to document post-shot surface effects fall into two general categories: (1) infrastructure, and (2) field equipment and materials. 


\section{C-7.1 Infrastructure Support}

This category includes the infrastructure typically provided at the company/agency level, such as vehicles (high-clearance, four-wheel drive if necessary), communication systems (telephones, radios), office space, and computer equipment. At test sites other than the NTS, the infrastructure category may be expanded to include the necessary logistical support for remote field work (food, housing, medical, etc.).

\section{C-7.2 Field Equipment and Materials}

Materials and equipment employed by the field geologist to map and document surface effects are not different from those used for more conventional geologic field mapping, as listed in Table $\mathrm{C}-2$.

\section{C-8.0 REPORTING}

This phase of the surface effects documentation effort is conducted in the office after the field mapping is complete.

\section{C-8.1 Data Compilation and Reduction}

To aid the photogrammetric mapping process, surface effects plotted on aerial photos in the field usually are consolidated onto as few photos as possible. A composite crack map of the site is then compiled and drafted. This is created by simply tracing (or digitizing) the surface data from the mosaic of aerial photos onto an overlying transparent material such as mylar. It should be noted that this interim effects map is not scale-stable and any distortion in the aerial photos is transferred. Notations such as " $\mathrm{H}$ " for hairline cracks or alphanumeric flags to expanded notes in the logbook are added to both the aerial photos and the derivative composite map as needed. The figure should also include a title, north arrow, scale, date, and names of members of the field team. 
Table C-2.

Field equipment and materials used for surface-effects mapping.

\begin{tabular}{|c|c|}
\hline Pocket transit (Brunton compass) & $\begin{array}{l}\text { To aid in mapping. All compasses should be set for the local } \\
\text { declination. }\end{array}$ \\
\hline Tape measure & $100-\mathrm{ft}$ or $30-\mathrm{m}$ length used to measure larger features. \\
\hline Centimeter scale & $\begin{array}{l}\text { For measuring small-scale features such as crack apertures } \\
\text { and vertical displacements. }\end{array}$ \\
\hline Camera & $\begin{array}{l}\text { Used to photodocument selected features. } 35-\mathrm{mm} \text { format } \\
\text { seems to be the most rugged and versatile, though Polaroid } \\
\text { instant photo format cameras also have proven useful. } \\
\text { Digital camera may be useful for on-site investigations. }\end{array}$ \\
\hline Optional field equipment & Jacob's staff, altimeter, etc. \\
\hline Aerial photographs & $\begin{array}{l}\text { Recent pre-shot photos are the standard; post-shot photos } \\
\text { would be ideal if they could be taken and made available for } \\
\text { use immediately after the test. Stereophotographic coverage } \\
\text { is most useful, however, aerial oblique photos are useful in } \\
\text { some situations. }\end{array}$ \\
\hline Pocket stereoscope & Used with photo-stereopairs. \\
\hline Geologic and topographic maps & $\begin{array}{l}\text { Relevant geologic quadrangle maps(s); topographic maps; } \\
\text { composite crack map for the area, etc. }\end{array}$ \\
\hline Writing/mapping paraphernalia & $\begin{array}{l}\text { Logbook; clipboard; protective folders for photos and maps; } \\
\text { pens and pencils; compass; straightedge; scale; etc. }\end{array}$ \\
\hline Appropriate field attire & $\begin{array}{l}\text { Sturdy field boots, sun hat, rugged pants for protection from } \\
\text { brush; adequate cold weather clothing as needed; etc. }\end{array}$ \\
\hline Personal field items & Water, first-aid kit, sun block, etc. \\
\hline Two-way radios & $\begin{array}{l}\text { Portable radios for communication among team members and } \\
\text { with base station; for coordination and safety. }\end{array}$ \\
\hline $\begin{array}{l}\text { *Geographic Positioning System } \\
\text { (GPS) }\end{array}$ & $\begin{array}{l}\text { For mapping in remote areas or areas with little or no map or } \\
\text { photo coverage. }\end{array}$ \\
\hline *Portable lap-top computer & $\begin{array}{l}\text { For field compilation of data; recording field notes; accessing } \\
\text { relevant data records. }\end{array}$ \\
\hline *Laser ranging/mapping systems & $\begin{array}{l}\text { Quick, accurate determination of range, azimuth, and } \\
\text { inclination to a target (such as SGZ). }\end{array}$ \\
\hline
\end{tabular}

* Items not previously used for surface effects mapping at the NTS, but which might prove desirable for future mapping tasks or for CTBT investigations. 
At this point, the data are evaluated and areas of questionable data or missed coverage are revisited in the field if possible.

\section{C-8.2 Production of Final Map}

For most NTS tests, the original aerial photos used during the field mapping are sent to the USGS for the photogrammetric mapping process. USGS personnel use field-mapped data along with the post-shot aerial photos to produce the final, scale-stable composite surface effects map for the test. The surface effects report and the interim composite map should accompany the field-marked photos.

If photogrammetric techniques or equipment are not available, other field methods (e.g., use of GPS equipment) might be required to produce a scale-stable map.

\section{C-8.3 Written Report}

The field geologists compile a final report which includes basic information such as the name of the test, when the mapping was done, and by whom it was done. A general description of the surface effects is provided, including extent of cracking, the relative abundance of different fracture types, degree of reactivation, and the occurrence of cracking (e.g., only on roads and drill pads, etc.). A general description of any surface collapse features is also provided.

Specific points deserving discussion include location and size of pressure ridges, very large cracks or cracks with vertical displacement, areas of block chatter, crack trends, and possible indications of or correlations with subsurface structure. Drainage patterns, topography, or roads that might have influenced crack patterns or the interpretation of mapping data would also be mentioned. Fault movements and post-shot status of any fault monitoring stations (e.g., on Pahute Mesa) are reported. The results of traverses across known surface or subsurface structure or survey lines are given as well. The interim composite surface effects map and any photos (with descriptions) are included. Optional information to be considered are special drawings or cross sections. A profile of the surface collapse sink also may be helpful. 
Any problems or limitations that might affect interpretations of the data should be mentioned. Factors that can affect observations, data quality, or interpretations can include weather (rain, snow, etc.) obliteration of features by equipment, or incomplete aerial photo coverage.

\section{C-8.4 Classification Issues}

Current classification guidelines must be followed in reporting all data related to nuclear testing. Information or reference to yield, cavity radius, test purpose, and configuration are typically not reported due to classification concerns. Also, several sensitive issues had to be addressed properly when working on previously unannounced tests. On such tests, no reference to time, date, landmarks, hole designation, or test name were made. Generally, the field geologists generated no classified data or reports.

\section{C-9.0 PERSONNEL}

\section{C-9.1 Size of Field Mapping Team}

Post-shot surface effects mapping at the NTS usually is conducted by two or more field geologists. Personnel safety concerns (remote field locations, rugged terrain, etc., discussed in Section (-5) dictate a minimum of two field mappers. Additional personnel, also following the buddy system, may be utilized. The potential for inclement weather (rain or snow that may obliterate surface effects) or the size of the task (large test with numerous cracks) may necessitate a more intense or large-scale mapping effort of a team consisting of four or more individuals. For many low-yield tests at the NTS a two-man team can complete the field mapping in less than one day, while larger tests in rugged terrain on the more distant Pahute Mesa could take four field geologists up to a week.

\section{C-9.2 Training Requirements}

\section{C-9.2.1 Skills}

Surface-effects mapping for hundreds of underground nuclear tests at the NTS has been conducted almost exclusively by geologists. The nature of surface-effects mapping entails 
particular observational skills, interpretation and correlation with surface and subsurface geology, and three-dimensional thinking processes; traits commonly required in the geologic profession. Each field geologist must demonstrate basic geologic mapping skills. Each team member should be familiar with the local geologic environment. At the NTS, geologists less familiar with surface effects are given on-the-job training by more experienced field geologists on several surface effects mapping tasks, before being given more independent mapping responsibilities.

\section{C-9.2.2 Clearances}

An effective surface effects mapping team at the NTS requires at least one member with a DOE Q-level security clearance. This permits access (on a need to know basis) to sensitive information, as well as access to the $\mathrm{CP}$ compound on shot-day. The remainder of the team may possess lower level clearances. Anyone who wishes to photograph anything in the forward areas of the NTS must have a photography permit, which also requires a Q-clearance. Photographers also are typically subject to specific procedures regarding the handling, development, and storage of photographic media and equipment.

\section{C-10.0 SUMMARY}

As presented in this appendix, procedures for mapping surface effects of underground nuclear tests have been developed and practiced by geologists during nearly forty years of underground testing at the NTS. The procedures were developed to successfully fulfill the requirements and objectives of the testing organizations (LANL, LLNL, and DSWA). These requirements may or may not be the same for other purposes or programs; consequently, these procedures may require modification to meet other user-defined needs. If mapping of surface effects is required in other programs, such as on-site inspections (OSIs) in support of the CTBT, this document will provide useful background information and a starting point for developing OSI procedures.

Though other methods, particularly remote sensing, might be developed for mapping surface effects, earth scientists will still be needed onsite to provide ground truth and interpretation of observed features. Certainly, improvements in technology such as field GPS units and computeraided mapping/data acquisition systems will make the geologists' job easier in the future. 
These procedures should be complemented by field training exercises at the NTS, to become familiar with the different types of surface effects and the techniques used to document them. This is especially true if new types of equipment and/or techniques are to be tested, or if personnel who are unfamiliar with surface effects features and documentation are to be utilized. This type of training will help ensure that features are completely and accurately documented in a timely manner, and that problems, either real or potential, are addressed before actual deployment on a surface-effects mapping effort. 


\section{DISTRIBUTION LIST}

DOE/NV/11718-122

BECHTEL NEVADA COMPANY

ATTN: B ALLEN

ATTN: D BARKER

ATTN: H BENSINGER

ATTN: S DRELLACK

ATTN: J GONZALES

ATTN: S GOLDSTEIN

ATTN: J MANNING

ATTN: G MACLEOD

ATTN: R MCCALL

ATTN: L PROTHRO

ATTN: M TOWNSEND

ATTN: D WILLIAMS

ATTN: BN CORRESPONDENCE CONTROL

DEPARTMENT OF DEFENSE

DEFENSE SPECIAL WEAPONS AGENCY

ATTN: FCTN B HARRIS-WEST

ATTN: PM D LINGER

ATTN: FCIN T B RISTVET

DEPARTMENT OF ENERGY

ATTN: OFFICE OF SCIENTIFIC AND TECHNICAL INFORMATION

NEVADA OPERATIONS OFFICE

ATTN: G ALLEN

ATTN: R FRIEDRICHS

ATTN: S LEEDOM

ATTN: TECHNICAL INFORMATION RESOURCE CENTER

LAWRENCE LIVERMORE NATIONAL LABORATORY

ATTN: N BURKHARD

ATTN: G PAWLOSKI

ATTN: F HEUZE

ATTN: D SMITH

ATTN: J ZUCCA

LOS ALAMOS NATIONAL LABORATORY

ATTN: F APP

ATTN: W BRUNISH

ATTN: C COSTA

ATTN: D ENGSTROM

ATTN: W HAWKINS

ATTN: T KUNKLE

ATTN: N MARUSAK

ATTN: J OGLE

ATTN: R PAPAZIAN

ATTN: R WARREN

ATTN: K WOHLETZ

UNITED STATES GEOLOGICAL SURVEY

ATTN: M GARCIA

ATTN: E JENKINS 
M97054146

|||||||||||||||||||||||||||||||||||||||||||||||||||||||

Report Number (14) DOE/NV/117/8=-122

Publ. Date (11) 199706

Sponsor Code (18)
UC Category (19)

DOE 